Prepared in cooperation with

New York State begartine in of Envronmental Conservation New York Department of State New York State Bepartment of Transportation New York City Department of Environmental Protection

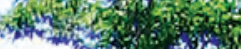

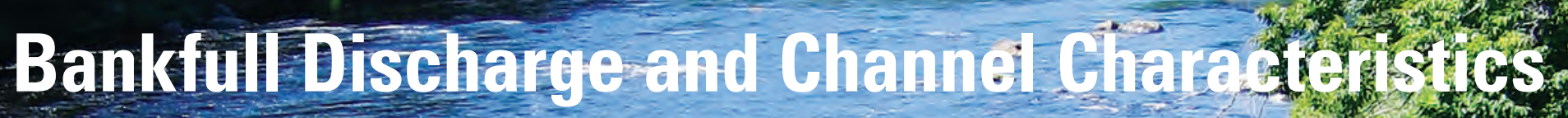
of Streams in New York State

\title{
济:
}

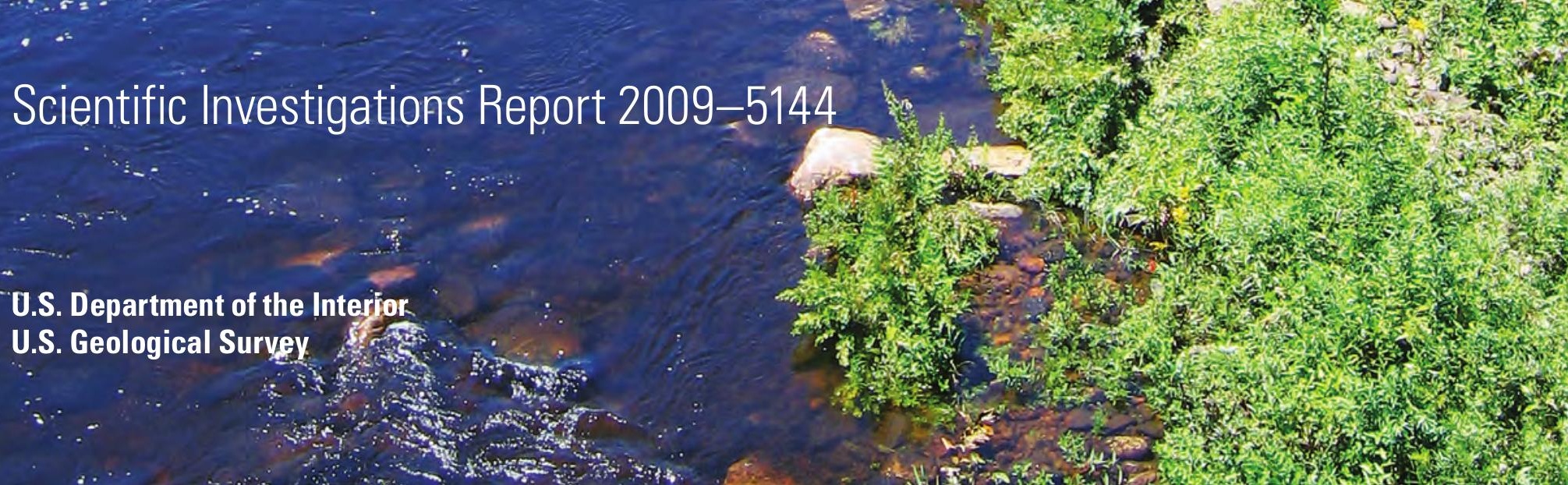


This page has been left blank intentionally. 


\section{Bankfull Discharge and Channel Characteristics of Streams in New York State}

By Christiane I. Mulvihill, Barry P. Baldigo, Sarah J. Miller, Douglas DeKoskie, and Joel DuBois

Prepared in cooperation with

New York State Department of Environmental Conservation

New York Department of State

New York State Department of Transportation

New York City Department of Environmental Protection

Scientific Investigations Report 2009-5144 


\title{
U.S. Department of the Interior \\ KEN SALAZAR, Secretary
}

\section{U.S. Geological Survey Suzette M. Kimball, Acting Director}

\author{
U.S. Geological Survey, Reston, Virginia: 2009 \\ Revised: August 2010
}

\begin{abstract}
For more information on the USGS — the Federal source for science about the Earth, its natural and living resources, natural hazards, and the environment, visit http://www.usgs.gov or call 1-888-ASK-USGS

For an overview of USGS information products, including maps, imagery, and publications, visit http://www.usgs.gov/pubprod

To order this and other USGS information products, visit http://store.usgs.gov
\end{abstract}

\begin{abstract}
Any use of trade, product, or firm names is for descriptive purposes only and does not imply endorsement by the U.S. Government.

Although this report is in the public domain, permission must be secured from the individual copyright owners to reproduce any copyrighted materials contained within this report.
\end{abstract}

Suggested citation: Mulvihill, C.I., Baldigo, B.P., Miller, S.J., DeKoskie, Douglas, and DuBois, Joel, 2009, Bankfull discharge and channel characteristics of streams in New York State: U.S. Geological Survey Scientific Investigations Report 2009-5144, $51 \mathrm{p}$. 


\section{Contents}

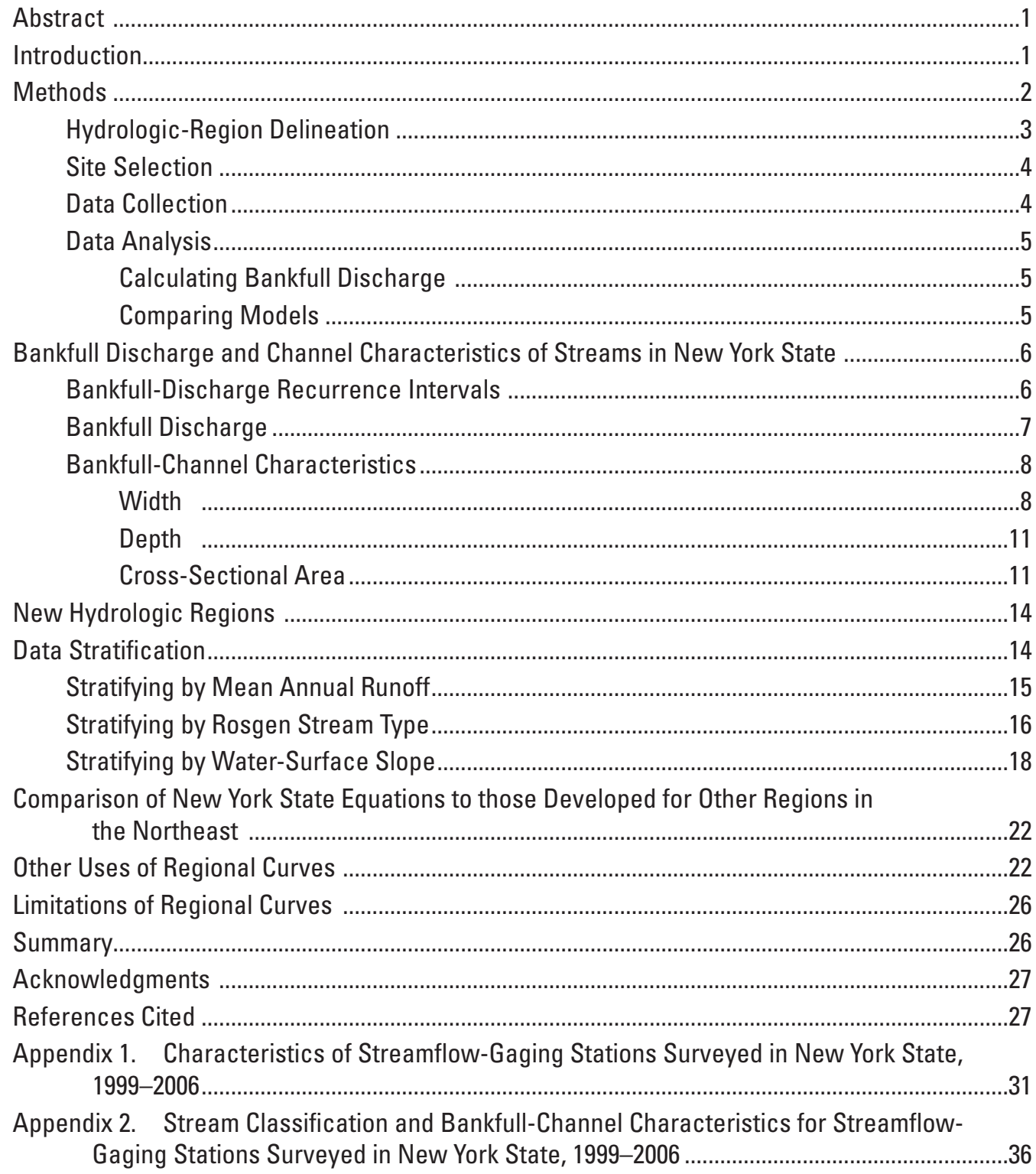

\section{Figures}

1. Map showing boundaries of hydrologic regions defined by Lumia (1991), and the locations of the 82 streamflow-gaging stations surveyed, 1999-2006................................3

2. Diagram showing mean (red), median (black), 10th, 25th, 75th, and 90th percentiles of recurrence intervals for seven hydrologic regions in New York and statewide ...........6

3. Graph showing bankfull discharge as a function of drainage area for seven hydrologic regions in New York State and statewide

4. Graph showing bankfull width as a function of drainage area for seven hydrologic regions in New York State and statewide 
5. Graph showing bankfull depth as a function of drainage area for seven hydrologic regions in New York State and statewide

6. Graph showing bankfull channel cross-sectional area as a function of drainage area for seven hydrologic regions in New York State and statewide

7. Map showing boundaries of the hydrologic regions defined by Lumia and others (2006), and the locations of the 82 streamflow-gaging stations surveyed, 1999-2006.

8. Graph showing bankfull discharge as a function of drainage area for six new hydrologic regions in New York State.

9. Graph showing histogram analysis of mean annual runoff distribution at

82 streamflow-gaging stations in New York State

10. Graph showing bankfull discharge as a function of drainage area stratified by mean annual runoff (MAR)

11. Graph showing bankfull discharge as a function of drainage area stratified by Rosgen stream type.

12. Graph showing histogram analysis of slope distribution at 82 streamflow-gaging stations in New York State

13. Graph showing bankfull discharge as a function of drainage area stratified by water-surface slope

14. Graph showing bankfull discharge as a function of drainage area for all of New York State, regions 4 and 7, and published curves for four other regions in the Northeast.

\section{Tables}

1. Regression equations for estimating bankfull discharge (in cubic feet per second) as a function of drainage area for seven hydrologic regions in New York State and statewide.

2. Similarities in bankfull discharge relations for 82 streamflow-gaging stations surveyed in seven hydrologic regions in New York State. Statistically similar relations, indicated by matching letters, are based on ANOVA analysis of the slopes and intercepts of regression lines having $p$-values greater than or equal to 0.05 .

3. Regression equations for estimating bankfull width (in feet) in unregulated streams in New York State, stratified by hydrologic region

4. Similarities in bankfull width relations for 281 cross-sections surveyed in seven hydrologic regions in New York State. Statistically similar relations, indicated by matching letters, are based on ANOVA analysis of the slopes and intercepts of regression lines having $p$-values greater than or equal to 0.05 .

5. Regression equations for estimating bankfull depth (in feet) in unregulated streams in New York State, stratified by hydrologic region

6. Similarities in bankfull depth relations for 281 cross-sections surveyed in seven hydrologic regions in New York State. Statistically similar relations, indicated by matching letters, are based on ANOVA analysis of the slopes and intercepts of regression lines having $p$-values greater than or equal to 0.05 .

7. Regression equations for estimating bankfull cross-sectional area (in square feet) in unregulated streams in New York State, stratified by hydrologic region 
8. Similarities in bankfull cross-sectional area relations for 281 cross-sections surveyed in seven hydrologic regions in New York State . . .13

9. Regression equations for estimating bankfull discharge (in cubic feet per second) in unregulated streams in New York State, stratified by new hydrologic regions

10. Similarities in bankfull discharge relations for 82 streamflow-gaging stations surveyed in six new hydrologic regions in New York State

11. Regression equations for estimating bankfull discharge (in cubic feet per second) as a function of drainage area, stratified by mean annual runoff 17

12. Similarities in bankfull-discharge relations, grouped by MAR range, for 82 streamflow-gaging stations surveyed in New York State

13. Regression equations for estimating bankfull discharge (in cubic feet per second) as a function of drainage area, stratified by Rosgen stream type

14. Similarities in bankfull-discharge relations, grouped by Rosgen stream type, for 82 streamflow-gaging stations surveyed in in New York State

15. Regression equations for estimating bankfull discharge (in cubic feet per second) as a function of drainage area, stratified by water-surface slope.

16. Similarities in bankfull -discharge relations, grouped by water-surface slope range, for 82 streamflow-gaging stations surveyed in in New York State

17. Similarities in bankfull-discharge relations for the New York statewide model, regions 4 and 7, and four other regions in the Northeast

18. Comparison of bankfull-discharge estimates from New York regional models to estimates from the Dunn and Leopold (1978) regional model for southeast Pennsylvania.

\section{Conversion Factors, Datum, and Acronyms}

\begin{tabular}{lcl}
\hline Multiply & By & To obtain \\
\hline \multicolumn{3}{c}{ Length } \\
\hline foot $(\mathrm{ft})$ & 0.3048 & meter $(\mathrm{m})$ \\
inch (in.) & 25.4 & millimeter $(\mathrm{mm})$ \\
\hline & Area & \\
\hline square foot $\left(\mathrm{ft}^{2}\right)$ & 0.09290 & square meter $\left(\mathrm{m}^{2}\right)$ \\
square mile $\left(\mathrm{mi}^{2}\right)$ & 259.0 & hectare $($ ha) \\
square mile $\left(\mathrm{mi}^{2}\right)$ & 2.590 & square kilometer $\left(\mathrm{km}^{2}\right)$ \\
\hline & Flow rate & \\
\hline cubic foot per second $\left(\mathrm{ft}^{3} / \mathrm{s}\right)$ & 0.02832 & cubic meter per second $\left(\mathrm{m}^{3} / \mathrm{s}\right)$ \\
cubic foot per second per square mile & 0.01093 & cubic meter per second per square kilometer \\
{$\left[\left(\mathrm{ft}^{3} / \mathrm{s}\right) / \mathrm{mi}^{2}\right]$} & & {$\left[\left(\mathrm{m}^{3} / \mathrm{s}\right) / \mathrm{km}^{2}\right]$} \\
\hline
\end{tabular}

Vertical coordinate information is referenced to the North American Vertical Datum of 1988 (NAVD 88).

Horizontal coordinate information is referenced to the North American Datum of 1983 (NAD 83).

Elevation, as used in this report, refers to distance above the vertical datum. 


$\begin{array}{ll}\text { LIST OF ACRONYMS } \\ \text { DCSWCD } & \text { Delaware County Soil and Water Conservation District } \\ \text { GCSWCD } & \text { Greene County Soil and Water Conservation District } \\ \text { GIS } & \text { Geographic information system } \\ \text { HEC-RAS } & \text { Hydraulic Engineering Center River Analysis System } \\ \text { HHM } & \text { Hydrologic and Habitat Modification } \\ \text { LOWESS } & \text { Locally weighted scatterplot smoother } \\ \text { MAR } & \text { Mean annual runoff } \\ \text { NPSCC } & \text { Nonpoint-Source Coordinating Committee } \\ \text { NYCDEP-SMP } & \text { New York City Department of Environmental Protection Stream } \\ & \text { Management Program } \\ \text { NYSDEC } & \text { New York State Department of Environmental Conservation } \\ \text { NYDOS } & \text { New York Department of State } \\ \text { NYSDOT } & \text { New York State Department of Transportation } \\ \text { USGS } & \text { U.S. Geological Survey }\end{array}$




\title{
Bankfull Discharge and Channel Characteristics of Streams in New York State
}

\author{
By Christiane I. Mulvihill', Barry P. Baldigo', Sarah J. Miller ${ }^{2}$, Douglas DeKoskie ${ }^{3}$, and Joel DuBois ${ }^{4}$
}

\section{Abstract}

Equations that relate drainage area to bankfull discharge and channel characteristics (such as width, depth, and crosssectional area) at gaged sites are needed to help define bankfull discharge and channel characteristics at ungaged sites and can be used in stream-restoration and protection projects, stream-channel classification, and channel assessments. These equations are intended to serve as a guide for streams in areas of similar hydrologic, climatic, and physiographic conditions. New York State contains eight hydrologic regions that were previously delineated on the basis of highflow (flood) characteristics. This report seeks to increase understanding of the factors affecting bankfull discharge and channel characteristics to drainage-area size relations in New York State by providing an in-depth analysis of seven previously published regional bankfull-discharge and channelcharacteristics curves.

Stream-survey data and discharge records from 281 cross sections at 82 streamflow-gaging stations were used in regression analyses to relate drainage area to bankfull discharge and bankfull-channel width, depth, and crosssectional area. The $\mathrm{R}^{2}$ and standard errors of estimate of each regional equation were compared to the $\mathrm{R}^{2}$ and standard errors of estimate for the statewide (pooled) model to determine if regionalizing data reduced model variability. It was found that regional models typically yield less variable results than those obtained using pooled statewide equations, which indicates statistically significant regional differences in bankfulldischarge and channel-characteristics relations.

Statistical analysis of bankfull-discharge relations found that curves for regions 4 and 7 fell outside the 95-percent confidence interval bands of the statewide model and had intercepts that were significantly different $(p \leq 0.10)$ from

\footnotetext{
${ }^{1}$ U.S. Geological Survey, 425 Jordan Rd., Troy, NY, 12180.

${ }^{2}$ U.S. Army Engineer Research and Development Center, 3909 Halls Ferry Rd., Vicksburg, MS 39180-6199.

${ }^{3}$ Integrated River Solutions, Inc., 9 River Rd., Ulster Park, NY 12487.

${ }^{4}$ Greene County Soil \& Water Conservation District, 907 County Office Building, Cairo, NY 12413.
}

the other five hydrologic regions. Analysis of channelcharacteristics relations found that the bankfull width, depth, and cross-sectional area curves for region 3 were significantly different $(\mathrm{p} \leq 0.05)$ from the other six regions.

It was hypothesized that some regional variability could be reduced by creating models for streams with similar physiographic and climatic characteristics. Available data on streamflow patterns and previous regional-curve research suggested that mean annual runoff, Rosgen stream type, and water-surface slope were the variables most likely to influence regional bankfull discharge and channel characteristics to drainage-area size relations. Results showed that although all of these factors had an influence on regional relations, most stratified models have lower $\mathrm{R}^{2}$ values and higher standard errors of estimate than the regional models.

The New York statewide (pooled) bankfull-discharge equation and equations for regions 4 and 7 were compared with equations for four other regions in the Northeast to evaluate region-to-region differences, and assess the ability of individual curves to produce results more accurate than those that would be obtained from one model of the northeastern United States. Results indicated that model slopes lack significant differences, though intercepts are significantly different. Comparison of bankfull-discharge estimates using different models shows that results could vary by as much as 100 percent depending on which model was used and indicated that regionalization improved model accuracy.

\section{Introduction}

Regional bankfull-discharge and channel-characteristic models use linear regression equations to relate bankfull discharge and bankfull-channel dimensions (width, depth, and cross-sectional area) to drainage-area size. Bankfull discharge is the flow that reaches the transition between the channel and its flood plain and is thus morphologically significant (Leopold and others, 1964). Bankfull may be functionally defined and identified as the stage or flow at which the stream is about to overtop its banks (Leopold and others, 1964; Leopold, 1994) and is reported to occur every 1 to 2 years (Dunne and Leopold, 1978; Rosgen, 1996; Harman and Jennings, 1999), 
or 1.5 years on average (Rosgen, 1994). Bankfull discharge is important to watershed managers because it is considered to be the most effective flow for moving sediment, forming or removing bars, forming or changing bends and meanders, and generally doing work that results in the average morphological characteristics of channels (Dunne and Leopold, 1978).

Different types of regional curves (models) have been introduced over the past 50 years to respond to a number of interrelated stream resource-management needs. Bankfulldischarge and channel-characteristics curves were first developed in the mid-1900s to describe stream depth, velocity, and cross-sectional area as functions of discharge to aid in the analyses and interpretation of sediment flow models at sites with U.S. Geological Survey (USGS) streamflow-gaging stations (Leopold and Maddock, 1953; Leopold and others, 1964). Investigations defining average channel dimensions and relating bankfull to effective discharge showed the relative consistency of average bankfull-channel dimensions and function for streams of similar drainage-area size (Wolman and Miller, 1960; Leopold and others, 1964). Regression models (regional curves) developed by Dunne and Leopold (1978), and reproduced with minor changes by Rosgen (1998a), depict several generalized regions of the United States. These generic models were developed with locally disparate data sets, so were inaccurate outside the sampling area because they did not account for specific differences in geomorphic characteristics caused by regional variations in landform, climate, geologic conditions, and runoff.

The demand for regional curves in New York State was spurred by an increase in the use of fluvial-geomorphology concepts in stream channel and bank restoration projects designed to decrease suspended sediment loads, reduce flood-related damages, improve aquatic habitat, and generally stabilize stream channels (U.S. Geological Survey, 2008). Geomorphology techniques such as those required for stream assessment, restoration design, and project monitoring have experienced an upswing in use among Federal, state, county, and local agencies in the State in part because appropriate use of these methods has been shown to reduce the need for repetitive site visits to remove sediments or repair streambanks, thus, reducing long-term channel-maintenance expenses (U.S. Geological Survey, 2008). Geomorphologybased restoration projects (often called "natural channel design" projects) require data that define what a stable stream channel should look like in a given region (U.S. Geological Survey, 2008). A critical set of information used in designing these geomorphologic restoration projects is the regional bankfull-discharge and channel-characteristics curves (U.S. Geological Survey, 2008). Prior to 1999, these regional data had not been compiled or analyzed in New York State.

This document summarizes a 9-year (2000-2008) statewide cooperative effort to develop regional bankfulldischarge and channel-characteristics models through a process established by the New York City Department of Environmental Protection Stream Management Program (NYCDEP-SMP; Miller and Davis, 2003; Powell and others,
2004). This study was led by the USGS and overseen by the New York State Hydrologic and Habitat Modification (HHM) subcommittee of the New York State NonpointSource Coordinating Committee (NPSCC). Other cooperators included the New York State Department of Environmental Conservation (NYSDEC), New York State Department of Transportation (NYSDOT), New York Department of State (NYDOS), Greene County Soil and Water Conservation District (GCSWCD), and Delaware County Soil and Water Conservation District (DCSWCD).

This report seeks to increase understanding of the factors affecting bankfull discharge and channel characteristics to drainage-area size relations in New York State by providing an in-depth analysis of seven previously published regional bankfull-discharge and channel-characteristics curves (Miller and Davis, 2003; Westergard and others, 2005; Mulvihill and others, 2005, 2006, 2007; Mulvihill and Baldigo, 2007). The objectives of the analysis are to determine if the curves: (1) correspond to other published ranges for bankfulldischarge return intervals, (2) differ significantly from each other sufficiently to support data regionalization, (3) differ significantly or are less accurate than statewide (pooled) curves, (4) change significantly or are less accurate than curves redeveloped using existing data for New York State and redefined (updated) hydrologic-region boundaries (Lumia and others, 2006), (5) can be improved (made more accurate) if bankfull-discharge data are stratified by mean annual runoff, Rosgen stream type, or slope, and (6) differ from those developed for other nearby states or provinces. Additional uses of regional curves are also identified and discussed to encourage increased dialogue on their potential utility beyond confirmation of bankfull features in reference reaches or other ungaged sites. The information presented herein provides a more in-depth analysis of the factors that effect bankfull discharge and channel characteristics in New York State and is not intended to supersede previously published hydrologicregion reports.

\section{Methods}

A detailed explanation of the methods used to select stable stream-channel sites, collect field data, and calculate bankfull discharge and bankfull-channel characteristics are given in Powell and others (2004). Explanations of any unique circumstances encountered at individual streamflow-gaging stations - for example, period of record less than 10 years, using a LOWESS (locally weighted scatterplot smoother; Ott and Longnecker, 2001) smooth to identify the elevation of bankfull stage, using the HEC-RAS computer program (Brunner, 1997) to calculate bankfull discharge, streamflowgaging station being inactive (lacking a current stage-todischarge rating curve) - can be found in previously published hydrologic-region reports (Miller and Davis, 2003; Westergard 
and others, 2005; Mulvihill and others, 2005, 2006, 2007; Mulvihill and Baldigo, 2007) and appendix 1.

\section{Hydrologic-Region Delineation}

A premise of this investigation was that a single model depicting bankfull discharge and channel characteristics to drainage-area size relations was not appropriate in New York State because of the highly variable physiography and climate of the State. Therefore, the state needed to be divided into hydrologic regions on the basis of the physiographic and geologic characteristics that affect streamflow. A previous investigation predicting the magnitude and frequency of flood discharges in New York divided the state into eight hydrologic regions (Lumia, 1991; fig. 1). These regional boundaries were based on multiple linear regression analyses that related the peak-discharge recurrence intervals to basin characteristics such as drainage area, main-channel slope, basin storage, mean annual precipitation, percentage of basin covered by forest area, mean main-channel elevation, and a basin-shape index (ratio of basin length to basin width) (Lumia, 1991). Resulting hydrologic regions refer to areas in which streamflow-gaging stations indicate a similarity of peak-discharge response that differs from the peak-discharge response in adjacent regions (Lumia, 1991). These hydrologic regions were considered ideal candidates for the preliminary stratification of bankfulldischarge and channel-characteristics data because it was hypothesized that peak-discharge and bankfull-discharge responses were being influenced by the same climatic and physiographic variables. This report presents a single model for hydrologic regions 1 and 2 (fig. 1), because in 2004, an additional 12 years of annual peak-discharge data updated skews (Lumia and Baevsky, 2000) for computing station flood-frequency curves as outlined in U.S. Water Resources Council Bulletin 17B (1981), and updated basin characteristics

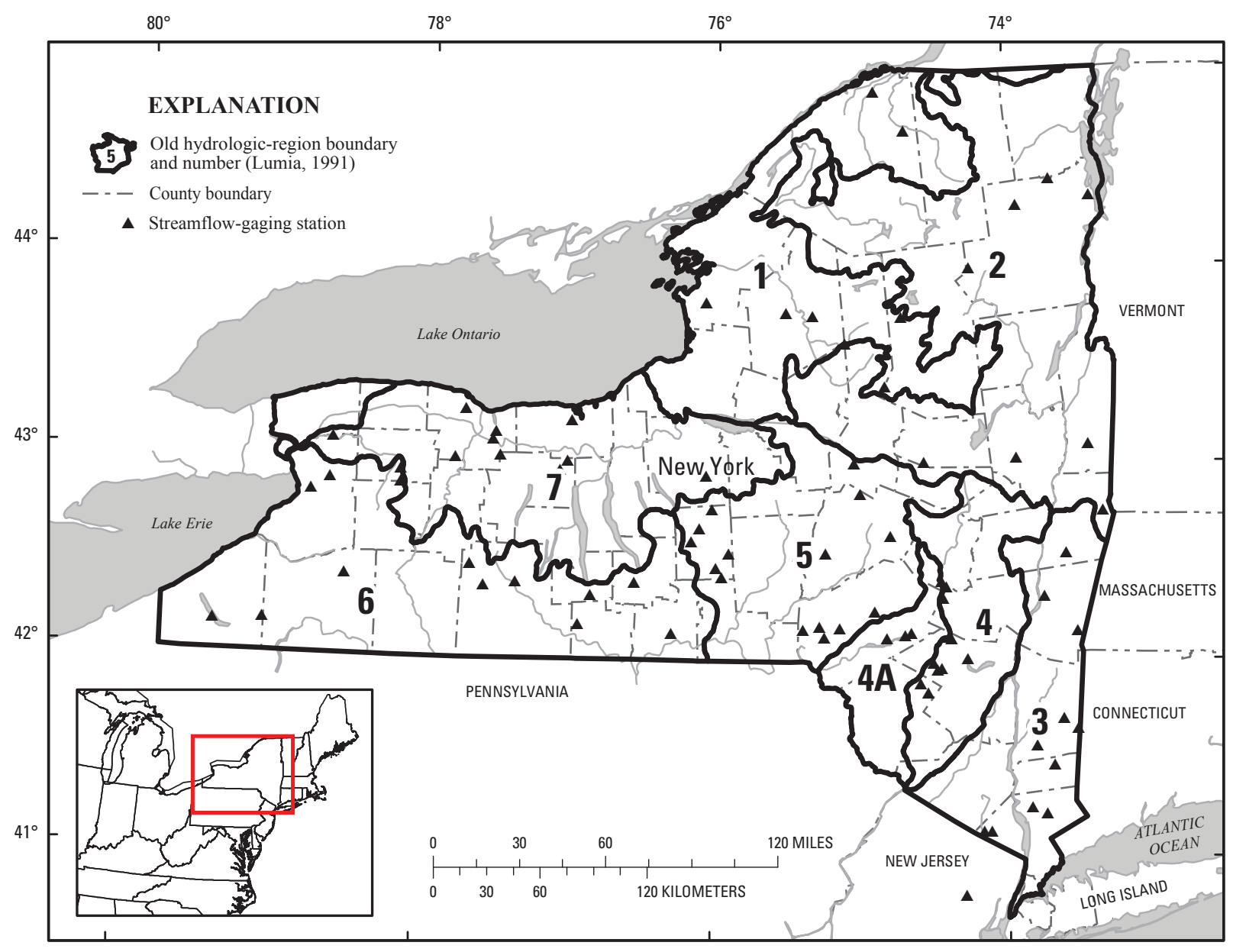

Base from U.S. Geological Survey Digital Data. Universal Transverse Mercator Projection, Zone18N, NAD83

Figure 1. Boundaries of hydrologic regions defined by Lumia (1991), and the locations of the 82 streamflow-gaging stations surveyed, 1999-2006. 
used for the multiple-regression analyses warranted revision of previous techniques (Lumia and others, 2006). After this revision, Regions 1 and 2 in the Adirondack region of northern New York were combined into a single hydrologic region.

\section{Site Selection}

The suitability of a stream for inclusion in a regionalcurve survey depended on the availability and accuracy of previously recorded data from the USGS streamflow-gaging station and the physical characteristics of the reach. Four to 16 streams representing a range of drainage-area sizes were surveyed in each hydrologic region. Selection criteria are summarized below (Miller and Davis, 2003; Powell and others, 2004).

Streamflow-gaging station characteristics:

- The USGS streamflow-gaging station should have at least 10 years of annual peak-discharge data, if possible. Both crest-stage gages, which record only the annual peak stage, and continuous-record streamflowgaging stations can be used.

- The streamflow-gaging station must be active with a current rating table, if possible.

- The streamflow-gaging station should not be in a regulated or urbanized basin.

- An inactive streamflow-gaging station can be reactivated and used, as long as the above conditions are met.

Reach characteristics:

- All reaches must be primarily alluvial (limited or intermittent bedrock or other morphological controls permitted) and consist of a single channel at bankfull stage.

- All reaches must include at least two sequences of a pool and a riffle or be at least 20 bankfull widths in length.

- The reach must be in sufficient equilibrium that bankfull indicators are readily identifiable.

- All reaches must meet the minimum requirements for slope-area calculation of discharge (uniform channel characteristics; flow confined to a single, trapezoidal channel; and water-surface-elevation drop of at least $0.50 \mathrm{ft}$ within the reach (Dalrymple and Benson, 1968), so that survey data can be used reliably in hydraulic analysis and calculation of bankfull discharge.

- All reaches should represent a single Rosgen (1996) stream type, if possible.

Each of New York's approximately 216 active continuous-record streamflow-gaging stations and
56 crest-stage partial-record stations were considered for regional-curve surveys using the above selection criteria (Szabo and others, 2006; U.S. Geological Survey, 2006). Only 44 of these 272 stations were suitable because many streamflow-gaging stations were on streams that were regulated or in urban settings; had wide flood plains and poorly defined or non-existent banks, braided or man-made channels, or banks reinforced with rip-rap; were too large to safely survey; had less than 10 years of peak-flow records; and (or) had no clearly identifiable bankfull indicators. To ensure that models relating bankfull discharge and channel characteristics to drainage-area size were as representative and statistically robust as possible, sample size was increased by adding 16 inactive streamflow-gaging stations, 17 containing more than 1 stream type, 3 with less than 10 years of record, 1 that was not operated by the USGS, and 1 that was in New Jersey (appendix 1). The analysis presented herein consists of data from 281 cross sections at 82 streamflow-gaging stations in 8 hydrologic regions mainly in New York (fig. 1, appendixes 1 and 2).

\section{Data Collection}

Preliminary reconnaissance of all sites entailed marking bankfull indicators, cross-section locations, and reach boundaries. Bankfull indicators typically consisted of (1) topographic break from vertical bank to flat flood plain;

(2) topographic break from steep slope to gentle slope;

(3) change in vegetation (for example, from treeless to trees);

(4) textural change in sediment; (5) scour break, or elevation below which no fine debris (needles, leaves, cones, seeds) occurs; and (6) back of point bar, lateral bar, or low bench (Castro and Jackson, 2001; Miller and Davis, 2003).

The upper and lower ends of the reach and the locations of cross sections were marked with rebar driven into the streambank above bankfull stage on one bank. Three to five cross sections at each site were placed in riffles or runs, away from channel-constricting structures such as bridges and culverts.

Each study reach was surveyed by methods described in Powell and others (2004). Longitudinal-profile and crosssectional surveys were conducted. The longitudinal-profile survey consisted of elevation measurements of the following features: rebar markers at the upper and lower reach limits; all bankfull indicators; and thalweg and water surface at each bankfull indicator, cross section, and pool-to-riffle transition. Cross-section surveys consisted of surveying bed and bank elevations, bankfull indicators, rebar that marked cross sections, and the width of the flood plain. The reference elevation for all surveys was the elevation used to define the stage-to-discharge relation. Channel material at each reach was characterized using a modification of the transect pebblecount procedure described in Powell and others (2004) to account for bank and in-channel material, sand and smaller particle sizes, and bedrock (Rosgen 1996). 


\section{Data Analysis}

This investigation used a combination of peak-flow records at streamflow-gaging stations and geomorphic field data collected during gage calibration surveys to calculate bankfull-discharge and bankfull-channel characteristics at 82 streamflow-gaging stations in New York. A summary of the graphical and statistical methods used to plot, analyze, and verify the regional-curve models presented herein follows.

\section{Calculating Bankfull Discharge}

Field data from the longitudinal-profile survey was entered into a standardized spreadsheet and analyzed to calculate bankfull stage and discharge. At most sites, a bankfull-elevation profile along the study reach was constructed by plotting a linear regression line through the surveyed bankfull-stage indicators. Except where noted in appendix 1, bankfull water-surface elevation (stage) and corresponding discharge at these sites were derived from these best-fit lines, rather than from surveyed bankfull indicators, to smooth local variations in slope that can result from intermittent disruptions such as debris piles or bedrock outcrops.

The bankfull stage at the streamflow-gaging station or staff plate at all sites was calculated as described above, and the bankfull discharge that corresponded to bankfull stage was obtained from the most current stage-to-discharge relation. Estimates of bankfull discharge were verified through a hydraulic analysis of the bankfull geomorphic data collected during the gage calibration survey as described below. Additional details are provided in Powell and others (2004).

1. The computer program NCALC (Jarrett and Petsch, 1985) was used to compute Manning's $n$, the roughness coefficient for the reach. Data required for this computation include discharge from the stage-todischarge relation, streambed and bankfull water-surface elevations at each cross section, and the distance along the thalweg between cross sections (Jarrett and Petsch, 1985).

2. The computer program HEC-RAS (U.S. Army Corps of Engineer's Hydraulic Engineering Center River Analysis System; Brunner, 1997) was used to calculate bankfull discharge from the water-surface elevation as follows: first, the reference elevation for the survey was entered as the starting elevation, and Manning's $n$ (from the NCALC analysis), channel-bed elevations at each cross section, the distance along the thalweg between cross sections, and several estimated discharges were input for each cross section. The discharge at the water-surface elevation calculated by HEC-RAS that most closely approximated the surveyed bankfull water-surface elevation was chosen as the bankfull discharge at each cross section; and finally, the average of these discharges from all cross sections in the reach was used as the bankfull discharge for the reach.
3. The bankfull discharge obtained from the stage-todischarge relation was compared with the bankfull discharge obtained from the HEC-RAS analysis. If the two discharges differed by 10 percent or less, the discharge obtained from the stage-to-discharge relation was used as the bankfull discharge, and the recurrence interval of this discharge was calculated. If the two discharges differed by more than 10 percent, the site and reach selection, discharge measurements, elevation of bankfull indicators, and development of the stage-todischarge relation were reviewed for sources of error. If no errors were found, the discharge closer to the 5-year recurrence interval was chosen.

\section{Comparing Models}

The accuracy of regression equations describing the relations between drainage-area size and bankfull discharge and channel characteristics was evaluated by examining the coefficient of determination $\left(\mathrm{R}^{2}\right)$ and the standard error of estimate. The $\mathrm{R}^{2}$ is a measure of the percentage of the variation in the response variable (bankfull discharge, width, depth, or cross-sectional area) that is accounted for by the variation in the explanatory variable (drainage-area size) (Helsel and Hirsch, 2002). The standard error of estimate is a measure of the average precision with which the regression equations estimate bankfull discharge, width, depth, or cross-sectional area for the streamflow-gaging stations used to develop the regression equations (Ries and Friesz, 2000). The standard error of estimate is a measure of the deviation of the observed data from the corresponding predictive data values and is similar to standard deviation for a normal distribution (Flynn, 2003). Standard error of estimate was also used to compute the 95-percent confidence interval for the regression lines. The 95-percent confidence interval indicates a band within which there is a 95-percent probability that estimates of bankfull discharge and channel characteristics for a known drainage area will occur. Regression lines bounded by the same confidence intervals are assumed to represent similar relations.

A major objective of the analyses was to determine if the models for each region differed from all other (or only selected) regions (or not). Preliminary ANCOVA results showed that the slope, intercept, or both for all hydraulic geometry and bankfull discharge models in some region(s) differed significantly from those in some of the other region(s). Because the ANCOVA results did not identify which regions differed additional ANOVA analyses were run in the program Statgraphics Plus ${ }^{\circledR}$ to test which regions differed significantly at $\mathrm{p}<0.05$ (Statgraphics Plus for Windows, 1996). If the $\mathrm{p}$-value was greater than 0.05 it meant there was more than a 5-percent probability that observed differences in slopes and intercepts were due solely to chance; thus, the tested models were considered similiar. 


\section{Bankfull Discharge and Channel Characteristics of Streams in New York State}

Stream-survey data and discharge records were stratified by regional, climatic, and physiographic variables in an effort to develop the best possible model for drainage area to bankfull discharge and channel-characteristics relations in New York. Following is a summary of (1) how regional models compared to a single statewide model, and (2) how reliably models that stratified data by mean annual runoff, Rosgen stream type, and slope predicted bankfull discharge.

\section{Bankfull-Discharge Recurrence Intervals}

Field identification of bankfull stage is sometimes hindered by uncertainty regarding the recurrence interval of bankfull discharge (Rosgen, 1996; Johnson and Heil, 1996). This investigation addressed this problem by examining if the bankfull-discharge recurrence interval of streams in New York corresponded to the 1- to 2-year range noted by previous investigations (Dunne and Leopold, 1978; Rosgen, 1996; Harman and Jennings, 1999; Castro and Jackson, 2001). A flood-frequency curve was used to calculate the recurrence interval of bankfull discharge for each of the 82 streamflow-gaging stations examined in this study. This curve was developed by fitting the logarithms of the annual peak discharges to a Pearson Type-III distribution according to guidelines recommended by the U.S. Water Resources Council (1981); the resulting data were analyzed through USGS floodfrequency programs (Kirby, 1981), and the frequency curves were adjusted to reflect historical information and high and low outliers (Lumia and others, 2006).

The initial field identification of bankfull stage assumed that bankfull discharge in streams across New York generally had recurrence intervals of 1-2 years, although some literature provides contradictory evidence (Cinotto, 2003; Thorne and others, 1997; Dudley, 2004). Thus, when more than one indicator of bankfull stage was identified in the field, the indicator that most closely corresponded to a recurrence interval of 1-2 years was generally used. Investigators acknowledge that following this protocol could produce erroneous bankfull-discharge and channel-characteristics models if the actual channel-forming discharge was not in

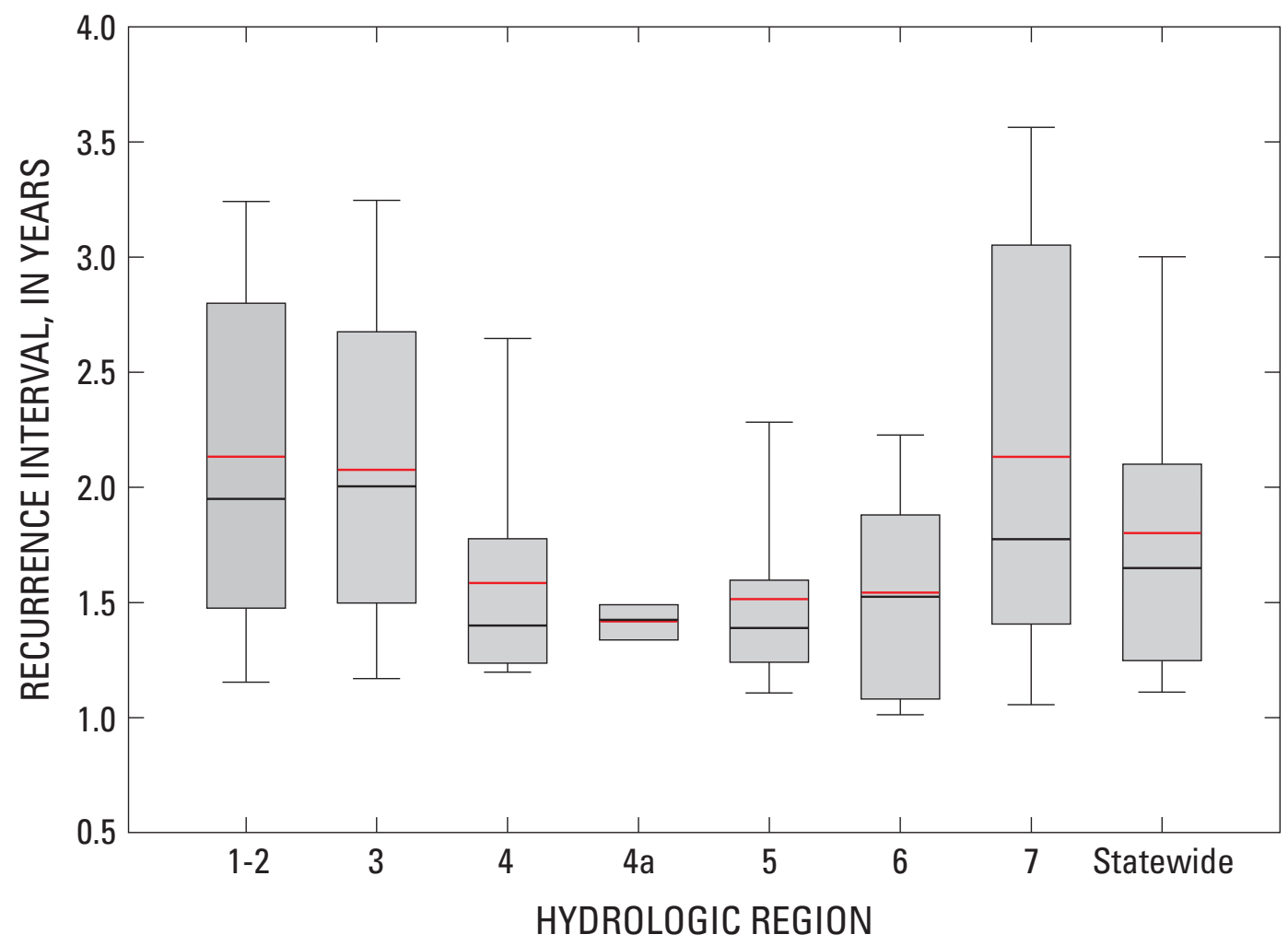

Figure 2. Mean (red), median (black), 10th, 25th, 75th, and 90th percentiles of recurrence intervals for seven hydrologic regions in New York and statewide. 
the 1- to 2-year range. However, these guidelines (1) ensured consistent identification of bankfull stage by different investigators, (2) allowed the models created in this study to be accurately compared to other models in the Northeast, and (3) modeled the flows of the greatest interest to watershed managers because those flows usually transport the greatest quantity of sediment material over time (Wolman and Miller, 1960).

The mean and upper and lower 95-percent confidence intervals of bankfull-discharge recurrence intervals varied considerably among hydrologic regions (fig. 2). The highest mean recurrence intervals were in regions 1 and 2, 3, and 7 and the lowest in regions 4, 4a, 5, and 6 (fig. 2). The average statewide recurrence interval was 1.77 years, which is slightly higher than the average 1.5-year interval predicted by Rosgen (1996), but within the 1- to 2.5-year range predicted by Leopold (1994). Because estimates of bankfull-discharge recurrence intervals varied among regions (fig. 2), identifying bankfull-stage indicators that correspond to the known recurrence-interval range of a hydrologic region could help investigators identify indicators that reflect local climatic and physiographic conditions.

\section{Bankfull Discharge}

Visual examination of the regionalized relations between bankfull discharge and drainage-area size reveals that bankfull-discharge responses were not as variable as the flood-frequency curves for the hydrologic regions (Lumia and others, 2006). For example, examination of the curves for regions 1 and 2, 4a, 5, and 6 reveals that these five regions have almost identical relations between bankfull discharge and drainage area, and region 3 differs from the above only in streams having drainage areas of $10 \mathrm{mi}^{2}$ or less (fig. 3). However, regions 4 and 7 clearly exhibit a different bankfulldischarge response; the region 4 model is above the upper statewide 95-percent confidence-interval band and the region 7 model is below the lower 95-percent statewide confidenceinterval band (fig. 3).

Comparison of the regional linear regression equations for estimating bankfull discharge as a function of drainagearea size to a single statewide model that included data from all 82 streamflow-gaging stations surveyed shows that all regional models except one (region 4) have higher $\mathrm{R}^{2}$ values and lower standard errors of estimate than the pooled statewide model (table 1). The highest standard error

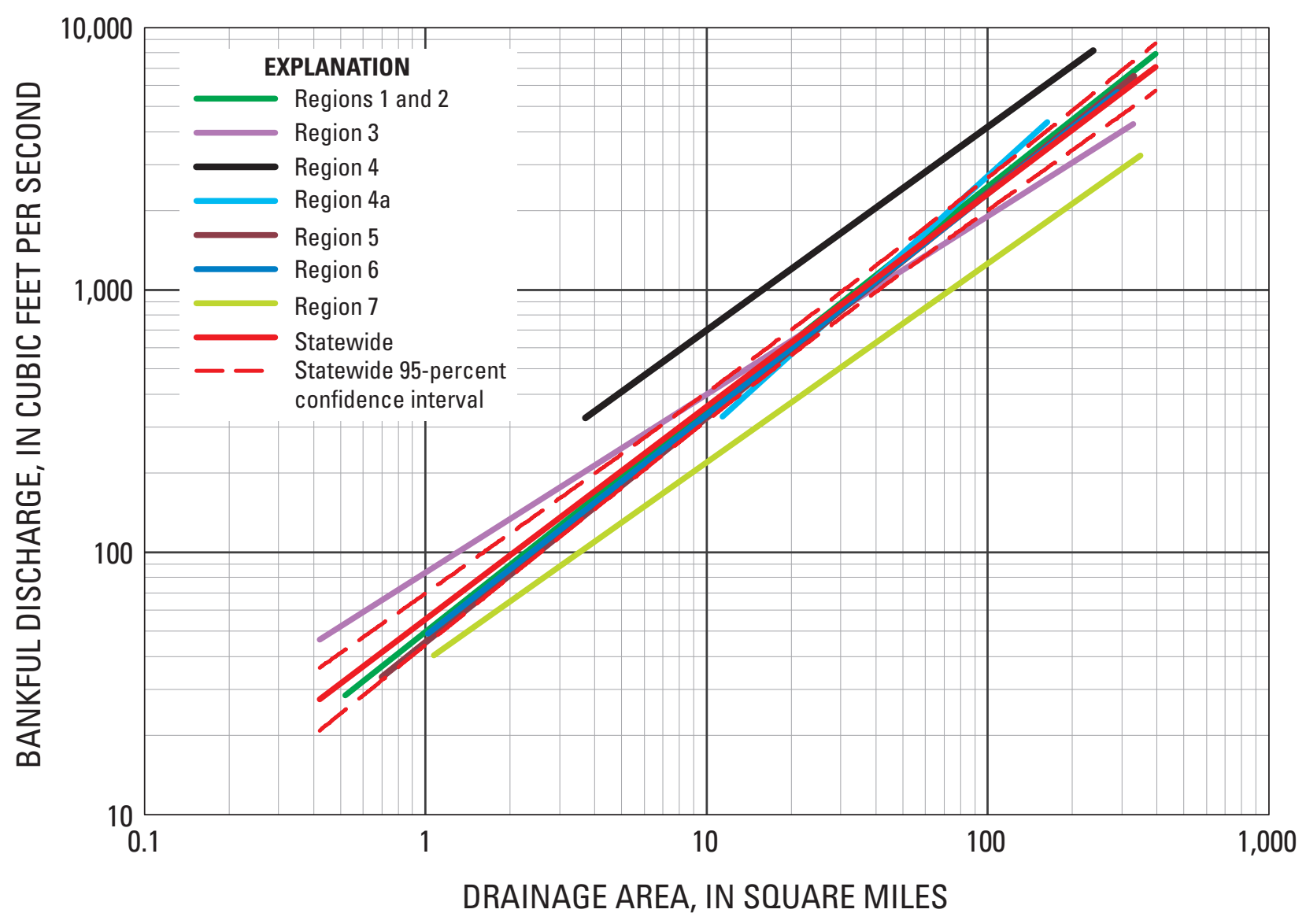

Figure 3. Bankfull discharge as a function of drainage area for seven hydrologic regions in New York State and statewide. 
Table 1. Regression equations for estimating bankfull discharge (in cubic feet per second) as a function of drainage area for seven hydrologic regions in New York State and statewide.

[DA, drainage area in square miles; $\mathrm{R}^{2}$, coefficient of determination]

\begin{tabular}{ccccc}
\hline $\begin{array}{c}\text { Hydrologic } \\
\text { region }\end{array}$ & $\begin{array}{c}\text { Number of } \\
\text { streamflow-gaging } \\
\text { stations surveyed }\end{array}$ & $\begin{array}{c}\text { Regression } \\
\text { equation }\end{array}$ & $\begin{array}{c}\text { Standard } \\
\text { error of estimate } \\
\text { (percent) }\end{array}$ & $\mathbf{R}^{\mathbf{2}}$ \\
\hline 1 and 2 & 16 & $49.6 \mathrm{DA}^{0.849}$ & 45 & 0.95 \\
3 & 12 & $83.8 \mathrm{DA}^{0.679}$ & 40 & .93 \\
4 & 10 & $117.2 \mathrm{DA}^{0.780}$ & 59 & .81 \\
$4 \mathrm{a}$ & 4 & $30.3 \mathrm{DA}^{0.980}$ & 16 & .99 \\
5 & 16 & $45.3 \mathrm{DA}^{0.856}$ & 36 & .96 \\
6 & 14 & $48.0 \mathrm{DA}^{0.842}$ & 52 & .90 \\
7 & 10 & $37.1 \mathrm{DA}^{0.765}$ & 39 & .94 \\
Statewide & 82 & $55.4 \mathrm{DA}^{0.810}$ & 54 & .89 \\
\hline
\end{tabular}

Table 2. Similarities in bankfull discharge relations for 82 streamflow-gaging stations surveyed in seven hydrologic regions in New York State. Statistically similar relations, indicated by matching letters, are based on ANOVA analysis of the slopes and intercepts of regression lines having p-values greater than or equal to 0.05 .

\begin{tabular}{|c|c|c|c|c|c|c|c|c|c|c|c|}
\hline \multirow{2}{*}{$\begin{array}{c}\text { Hydrologic region } \\
1 \text { and } 2\end{array}$} & \multirow{2}{*}{$\begin{array}{c}\text { Intercept } \\
49.6\end{array}$} & \multirow{2}{*}{$\begin{array}{l}\text { Slope } \\
0.849\end{array}$} & \multicolumn{9}{|c|}{ Similarities in bankful discharge } \\
\hline & & & A & B & C & & & & & & \\
\hline 3 & 83.8 & .679 & & & & D & E & & & & \\
\hline 4 & 117.12 & .780 & & & & & & $\mathrm{~F}$ & & & \\
\hline $4 a$ & 30.3 & .980 & & & $\mathrm{C}$ & & $\mathrm{E}$ & $\mathrm{F}$ & & $\mathrm{H}$ & I \\
\hline 5 & 45.3 & .856 & A & & & & & & G & $\mathrm{H}$ & \\
\hline 6 & 48.0 & .842 & & B & & $\mathrm{D}$ & & & G & & I \\
\hline 7 & 37.1 & .754 & & & & & & & & & \\
\hline
\end{tabular}

of estimate was in region 4 (table 1), possibly because this mountainous area experiences highly variable mean annual runoff, as discussed further on. ANOVA analysis of curve similarities showed that, as expected, the slopes and intercepts of the region 7 model were significantly different (table 2 ). The intercepts of the region 4 and $4 \mathrm{a}$ models were not significantly different from one another at $\mathrm{p} \leq 0.05$ (table 2 ; $\mathrm{p}=0.081$ ). However, this is most likely due to the fact that only four streamflow-gaging stations were surveyed in region $4 \mathrm{a}$ (table 1).

\section{Bankfull-Channel Characteristics}

Data from bankfull cross-section surveys were used to develop regional linear regression equations for the relations between drainage area and bankfull width, depth, and cross-sectional area. Following is a summary of (1) how reliably these equations predicted channel characteristics in each hydrologic region, and (2) how these regional models compared to a single statewide model.

\section{Width}

Visual examination of the regional models for the relation between bankfull width and drainage-area size reveals that the curves for regions 4 and 7 appear to be higher and lower, respectively, than the other five models (fig. 4). In all regions except one (region 6), regionalizing the data decreased standard errors of estimate and increased $\mathrm{R}^{2}$ values (table 3 ). Even though the region 4 curve was above the 95 -percent confidence interval bands of the statewide model (fig. 4), 


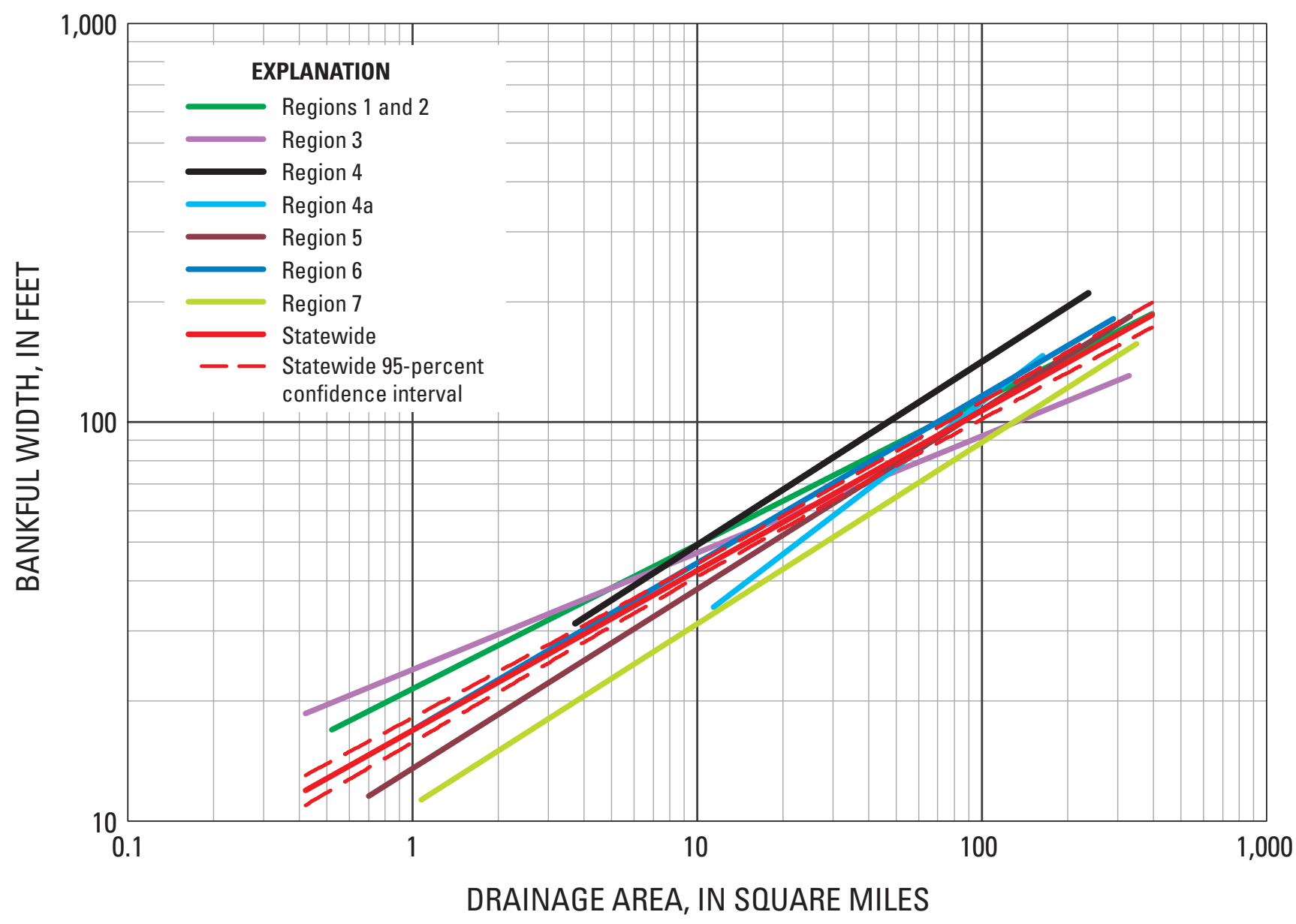

Figure 4. Bankfull width as a function of drainage area for seven hydrologic regions in New York State and statewide.

Table 3. Regression equations for estimating bankfull width (in feet) in unregulated streams in New York State, stratified by hydrologic region.

[DA, drainage area in square miles; $\mathrm{R}^{2}$, coefficient of determination]

\begin{tabular}{ccccc}
\hline Hydrologic region & $\begin{array}{c}\text { Number of } \\
\text { cross sections } \\
\text { surveyed }\end{array}$ & Regression equation & $\begin{array}{c}\text { Standard error } \\
\text { of estimate } \\
\text { (percent) }\end{array}$ & $\mathbf{R}^{\mathbf{2}}$ \\
\hline 1 and 2 & 55 & $21.5 \mathrm{DA}^{0.362}$ & 28 & 0.89 \\
3 & 40 & $24.0 \mathrm{DA}^{0.292}$ & 23 & .85 \\
4 & 21 & $17.1 \mathrm{DA}^{0.460}$ & 26 & .87 \\
$4 \mathrm{a}$ & 9 & $9.1 \mathrm{DA}^{0.545}$ & 10 & .98 \\
5 & 73 & $13.5 \mathrm{DA}^{0.449}$ & 27 & .92 \\
6 & 50 & $16.9 \mathrm{DA}^{0.419}$ & 36 & .79 \\
7 & 33 & $10.8 \mathrm{DA}^{0.458}$ & 30 & .89 \\
Statewide & 281 & $16.9 \mathrm{DA}^{0.401}$ & 32 & .84 \\
\hline
\end{tabular}


Table 4. Similarities in bankfull width relations for 281 cross-sections surveyed in seven hydrologic regions in New York State. Statistically similar relations, indicated by matching letters, are based on ANOVA analysis of the slopes and intercepts of regression lines having $\mathrm{p}$-values greater than or equal to 0.05 .

\begin{tabular}{|c|c|c|c|c|c|c|c|c|c|c|}
\hline \multirow{2}{*}{$\begin{array}{c}\text { Hydrologic region } \\
1 \text { and } 2\end{array}$} & \multirow{2}{*}{$\begin{array}{c}\text { Intercept } \\
21.5\end{array}$} & \multirow{2}{*}{$\begin{array}{l}\text { Slope } \\
0.362\end{array}$} & \multicolumn{8}{|c|}{ Similarities in bankful width } \\
\hline & & & A & B & C & & & & & \\
\hline 3 & 83. & .292 & & & & & & & & \\
\hline 4 & 17.1 & .460 & A & & & D & E & & & \\
\hline $4 a$ & 9.1 & .545 & & & $\mathrm{C}$ & & E & $\mathrm{F}$ & G & $\mathrm{H}$ \\
\hline 5 & 13.5 & .449 & & & & & & $\mathrm{~F}$ & & \\
\hline 6 & 16.9 & .419 & & B & & $\mathrm{D}$ & & & G & \\
\hline 7 & 10.8 & .458 & & & & & & & & $\mathrm{H}$ \\
\hline
\end{tabular}

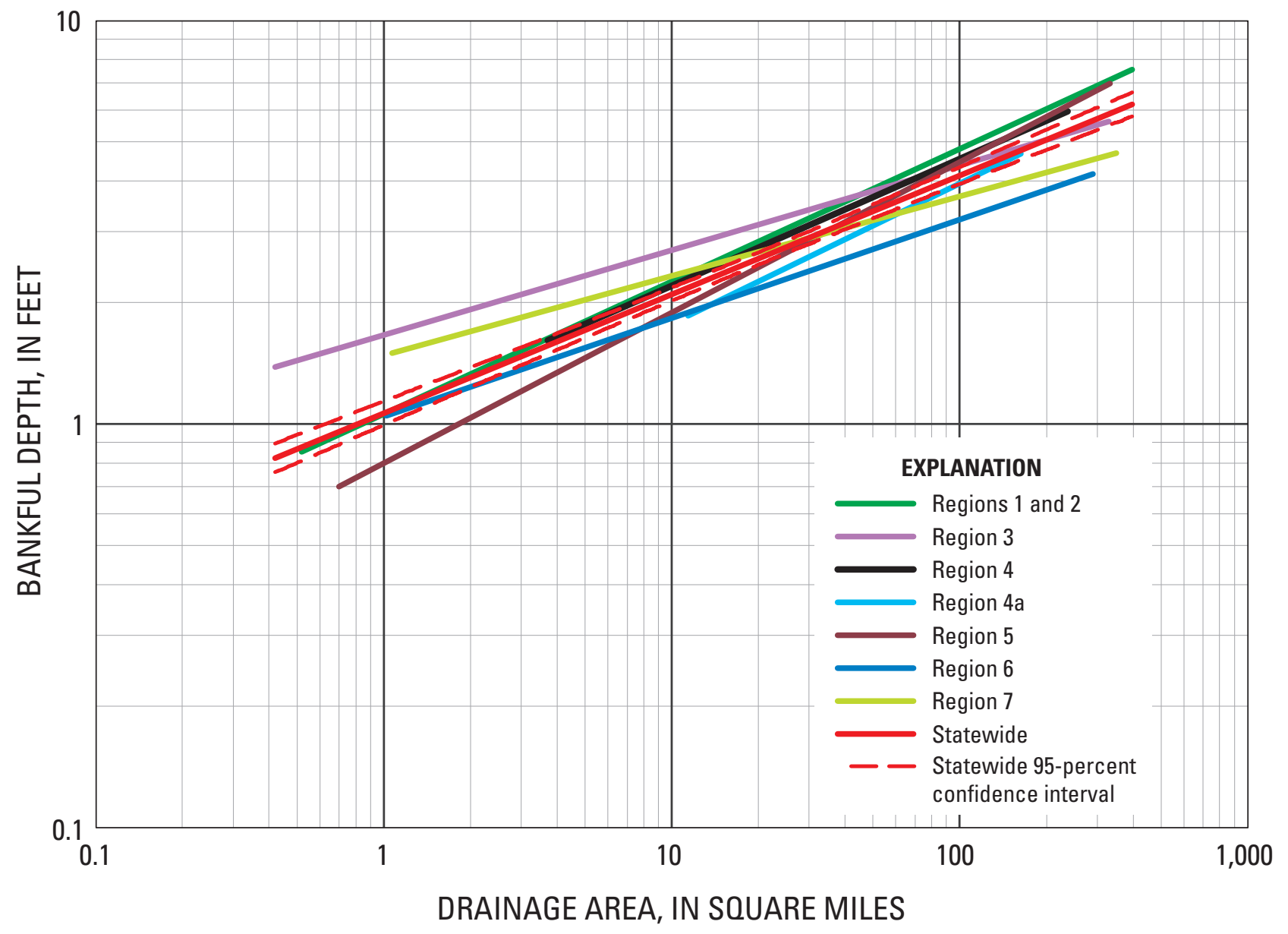

Figure 5. Bankfull depth as a function of drainage area for seven hydrologic regions in New York State and statewide. 
ANOVA analysis found it to be statistically similar to the models for regions 1 and 2,6, and 4a (table 4). Likewise, although the region 7 curve was below the 95-percent confidence interval bands of the statewide model (fig. 4), ANOVA analysis found it to be statistically similar to the region 4 a model (table 4).

\section{Depth}

Visual examination of the relations between bankfull depth and drainage-area size reveals some regional variation in this channel characteristic, especially in streams with drainage areas of $10 \mathrm{mi}^{2}$ or less (fig. 5). Regionalization of bankfulldepth decreased standard errors of estimate in all regions except one (region 7), and increased $\mathrm{R}^{2}$ values in all regions except two (regions 6 and 7, table 5). ANOVA analysis of curve similarities confirmed that the visibly different slope and intercept of the region 3 , are significantly different $(p \leq 0.05)$ from the other six models (table 6).

\section{Cross-Sectional Area}

Visual examination of the regional models for bankfull cross-sectional area reveals a fair amount of regional variability in this parameter, especially in streams with drainage areas of $10 \mathrm{mi}^{2}$ or less (fig. 6). For example, a stream having a drainage area of $1 \mathrm{mi}^{2}$ would have a crosssectional area of $10 \mathrm{ft}^{2}$ in region 5 , but $40 \mathrm{ft}^{2}$ in region 3 (fig. 6). Regionalization decreased standard errors of estimate in every region, and improved $\mathrm{R}^{2}$ values in all but 2 regions (regions 4 and 6, table 7). Once again ANOVA analysis of curve similarities confirmed that the visibly different slope and intercept of the region 3 model are significantly different $(\mathrm{p} \leq 0.05)$ from the other six models (table 8).

Table 5. Regression equations for estimating bankfull depth (in feet) in unregulated streams in New York State, stratified by hydrologic region.

[DA, drainage area in square miles; $\mathrm{R}^{2}$, coefficient of determination]

\begin{tabular}{|c|c|c|c|c|}
\hline Hydrologic region & $\begin{array}{l}\text { Number of } \\
\text { cross sections } \\
\text { surveyed }\end{array}$ & Regression equation & $\begin{array}{l}\text { Standard error } \\
\text { of estimate } \\
\text { (percent) }\end{array}$ & $\mathbf{R}^{2}$ \\
\hline 3 & 40 & $1.66 \mathrm{DA}^{0.210}$ & 21 & .77 \\
\hline 4 & 21 & $1.07 \mathrm{DA}^{0.314}$ & 19 & .84 \\
\hline 6 & 50 & $1.04 \mathrm{DA}^{0.244}$ & 30 & .64 \\
\hline 7 & 33 & $1.47 \mathrm{DA}^{0.199}$ & 35 & .52 \\
\hline Statewide & 281 & $1.06 \mathrm{DA}^{0.294}$ & 31 & .76 \\
\hline
\end{tabular}

Table 6. Similarities in bankfull depth relations for 281 cross-sections surveyed in seven hydrologic regions in New York State. Statistically similar relations, indicated by matching letters, are based on ANOVA analysis of the slopes and intercepts of regression lines having $p$-values greater than or equal to 0.05 .

\begin{tabular}{|c|c|c|c|c|c|c|c|c|c|c|}
\hline \multirow{2}{*}{$\begin{array}{c}\text { Hydrologic region } \\
1 \text { and } 2\end{array}$} & \multirow{2}{*}{$\begin{array}{c}\text { Intercept } \\
1.06\end{array}$} & \multirow{2}{*}{$\begin{array}{l}\text { Slope } \\
0.329\end{array}$} & \multicolumn{8}{|c|}{ Similarities in bankful depth } \\
\hline & & & & & & & & & & \\
\hline 3 & 1.66 & .210 & & & & & & & & \\
\hline 4 & 1.07 & .314 & $\mathrm{~A}$ & & $\mathrm{C}$ & $\mathrm{D}$ & $\mathrm{E}$ & & & \\
\hline $4 a$ & 0.79 & .350 & & $\mathrm{~B}$ & & & $\mathrm{E}$ & $\mathrm{F}$ & G & $\mathrm{H}$ \\
\hline 5 & .82 & .373 & & & $\mathrm{C}$ & & & $\mathrm{F}$ & & \\
\hline 6 & 1.04 & .244 & & & & & & & G & \\
\hline 7 & 1.47 & .199 & & & & $\mathrm{D}$ & & & & $\mathrm{H}$ \\
\hline
\end{tabular}




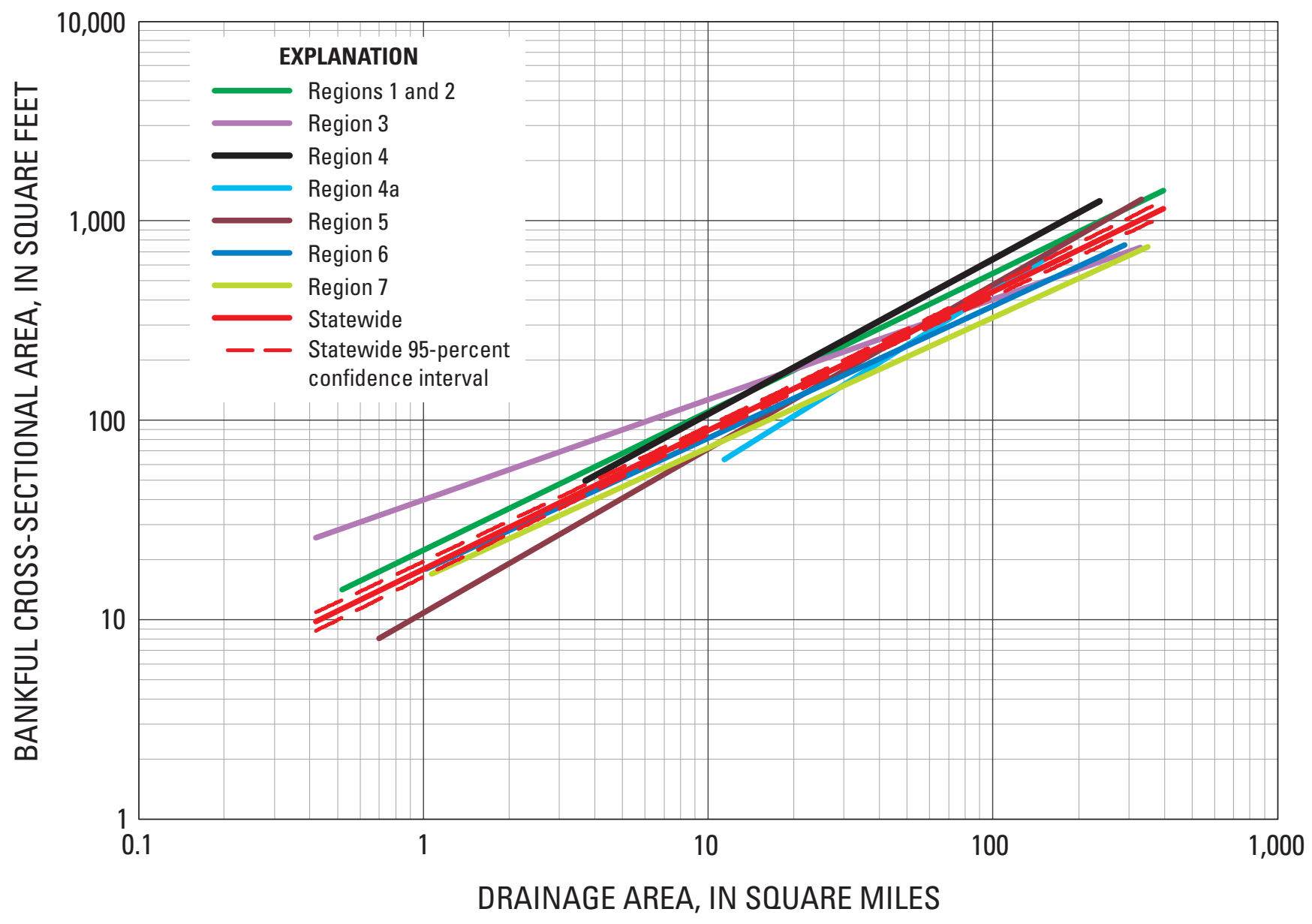

Figure 6. Bankfull channel cross-sectional area as a function of drainage area for seven hydrologic regions in New York State and statewide.

Table 7. Regression equations for estimating bankfull cross-sectional area (in square feet) in unregulated streams in New York State, stratified by hydrologic region.

[DA, drainage area in square miles; $\mathrm{R}^{2}$, coefficient of determination]

\begin{tabular}{|c|c|c|c|c|}
\hline Hydrologic region & $\begin{array}{l}\text { Number of } \\
\text { cross sections } \\
\text { surveyed }\end{array}$ & Regression equation & $\begin{array}{l}\text { Standard error } \\
\text { of estimate } \\
\text { (percent) }\end{array}$ & $\mathbf{R}^{2}$ \\
\hline 1 and 2 & 55 & $22.3 \mathrm{DA}^{0.694}$ & 24 & 0.97 \\
\hline 3 & 40 & $39.8 \mathrm{DA}^{0.503}$ & 27 & .92 \\
\hline 4 & 21 & $17.9 \mathrm{DA}^{0.777}$ & 35 & .91 \\
\hline $4 a$ & 9 & $7.2 \mathrm{DA}^{0.894}$ & 18 & .97 \\
\hline 6 & 50 & $17.6 \mathrm{DA}^{0.662}$ & 38 & .89 \\
\hline 7 & 33 & $15.9 \mathrm{DA}^{0.656}$ & 25 & .95 \\
\hline Statewide & 281 & $17.9 \mathrm{DA}^{0.696}$ & 41 & .91 \\
\hline
\end{tabular}


Table 8. Similarities in bankfull cross-sectiional area relations for 281 cross-sections surveyed in seven hydrologic regions in New York State. Statistically similar relations, indicated by matching letters, are based on ANOVA analysis of the slopes and intercepts of regression lines having $p$-values greater than or equal to 0.05 .

\begin{tabular}{|c|c|c|c|c|c|c|c|c|}
\hline Hydrologic region & Intercept & Slope & \multicolumn{6}{|c|}{ Similarities in bankful cross-sectional area } \\
\hline 1 and 2 & 22.3 & 0.694 & A & & & & & \\
\hline 3 & 39.8 & .503 & & & & & & \\
\hline 4 & 17.9 & .777 & A & B & & & & \\
\hline $4 a$ & 7.2 & .894 & & B & $\mathrm{C}$ & & $\mathrm{E}$ & $\mathrm{F}$ \\
\hline 5 & 10.8 & .823 & & & $\mathrm{C}$ & & & \\
\hline 6 & 17.6 & .662 & & & & $\mathrm{D}$ & $\mathrm{E}$ & \\
\hline 7 & 15.9 & .656 & & & & $\mathrm{D}$ & & $\mathrm{F}$ \\
\hline
\end{tabular}

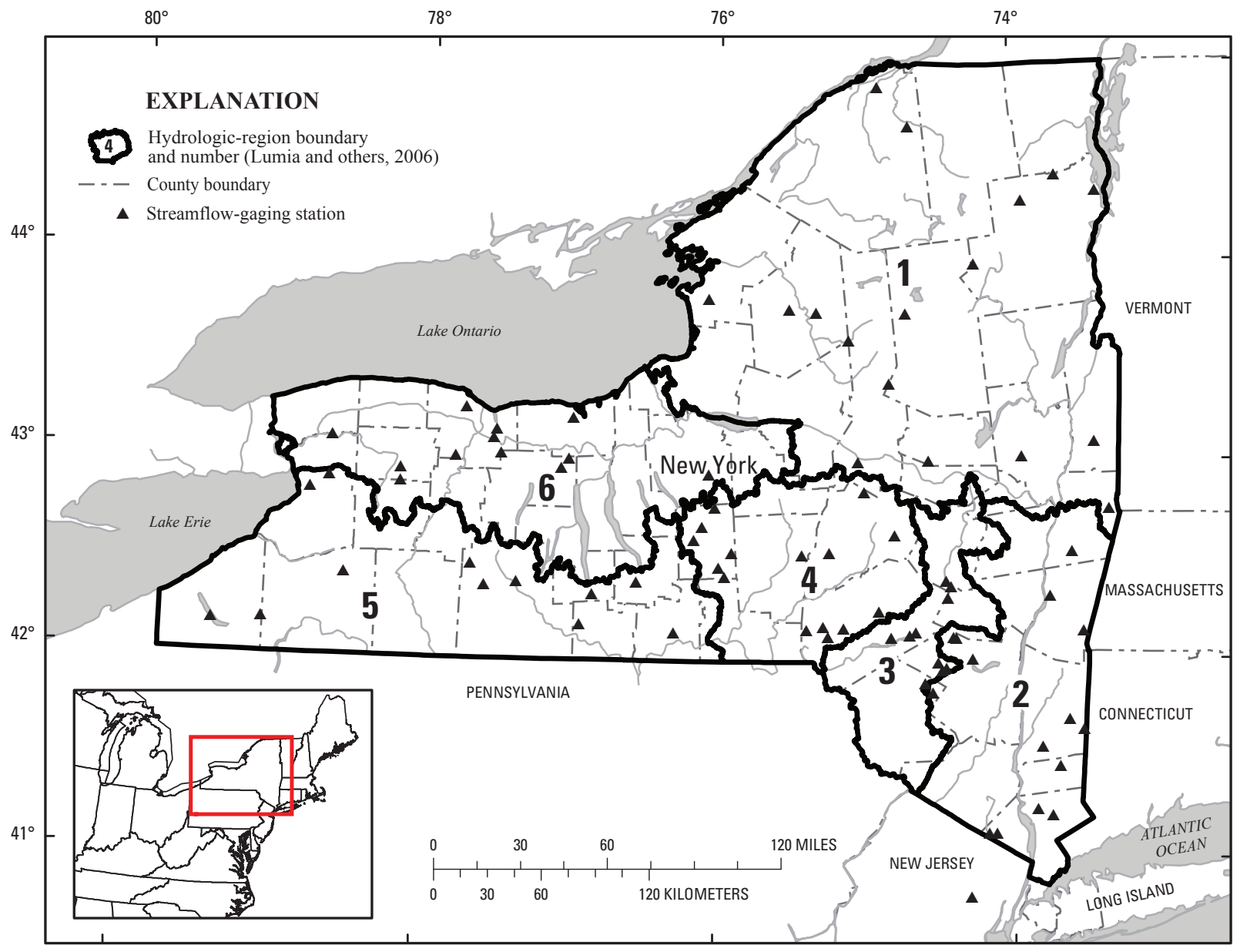

Base from U.S. Geological Survey Digital Data. Universal Transverse Mercator Projection, Zone18N, NAD83

Figure 7. Boundaries of the hydrologic regions defined by Lumia and others (2006), and the locations of the 82 streamflow-gaging stations surveyed, 1999-2006. 


\section{New Hydrologic Regions}

The original hydrologic-region boundaries (fig. 1; Lumia, 1991) were re-drawn in 2006 (fig. 7; Lumia and others, 2006); the basis for this change was improved hydrologic and statistical analyses made possible by 12 additional years of peak-discharge records and the availability of refined basincharacteristics data through improved geographic information system (GIS) coverages and techniques (Lumia and others, 2006). A brief discussion of how these new regional delineations affected the relations between bankfull discharge and drainage-area size follows.

Examination of revised bankfull-discharge curves for the six new hydrologic regions indicates that relations for streams in new regions 3 and 6 differ slightly from the other four (fig. 8). This is not surprising because the boundaries of new region 3 (fig. 7) are similar to the boundaries of old region 4 (fig. 1), and the boundaries of new region 6 (fig. 7) are almost the same as the boundaries of old region 7 (fig. 1). The average standard errors of estimates for all six new hydrologic regions is 48 percent (table 9), compared to 41 percent for the seven original hydrologic regions (table 1), and the mean $\mathrm{R}^{2}$ is 0.89 for the six new hydrologic regions (table 9), compared to 0.92 for the seven original hydrologic regions (table 1). Although these results initially suggest that the linear regression equations for the seven original hydrologic regions may be slightly more accurate than the equations for the six new hydrologic regions, a $t$-test found no statistically significant difference between mean standard errors of estimate or mean $\mathrm{R}^{2}$ values between the old and new hydrologic-region delineations. This result suggests that both sets of regional models work equally well. ANOVA analysis of curve similarities showed that, as expected, the slope and intercept of the region 6 model were significantly different (table 10). The region 3 model was statistically similar to regions 2 and 5 (table 10) because only ten streamflow-gaging stations were surveyed (table 9) and the presence of marginally significant similarities in intercepts (table $10 ; p=0.078$ and 0.066 in regions 2 and 5 , respectively).

\section{Data Stratification}

Data stratification, a process by which separate models are created for streamflow-gaging stations sharing certain physiographic and climatic variables, was evaluated in an effort to further reduce the prediction errors for bankfull discharges estimated by the hydrologic-region models. In

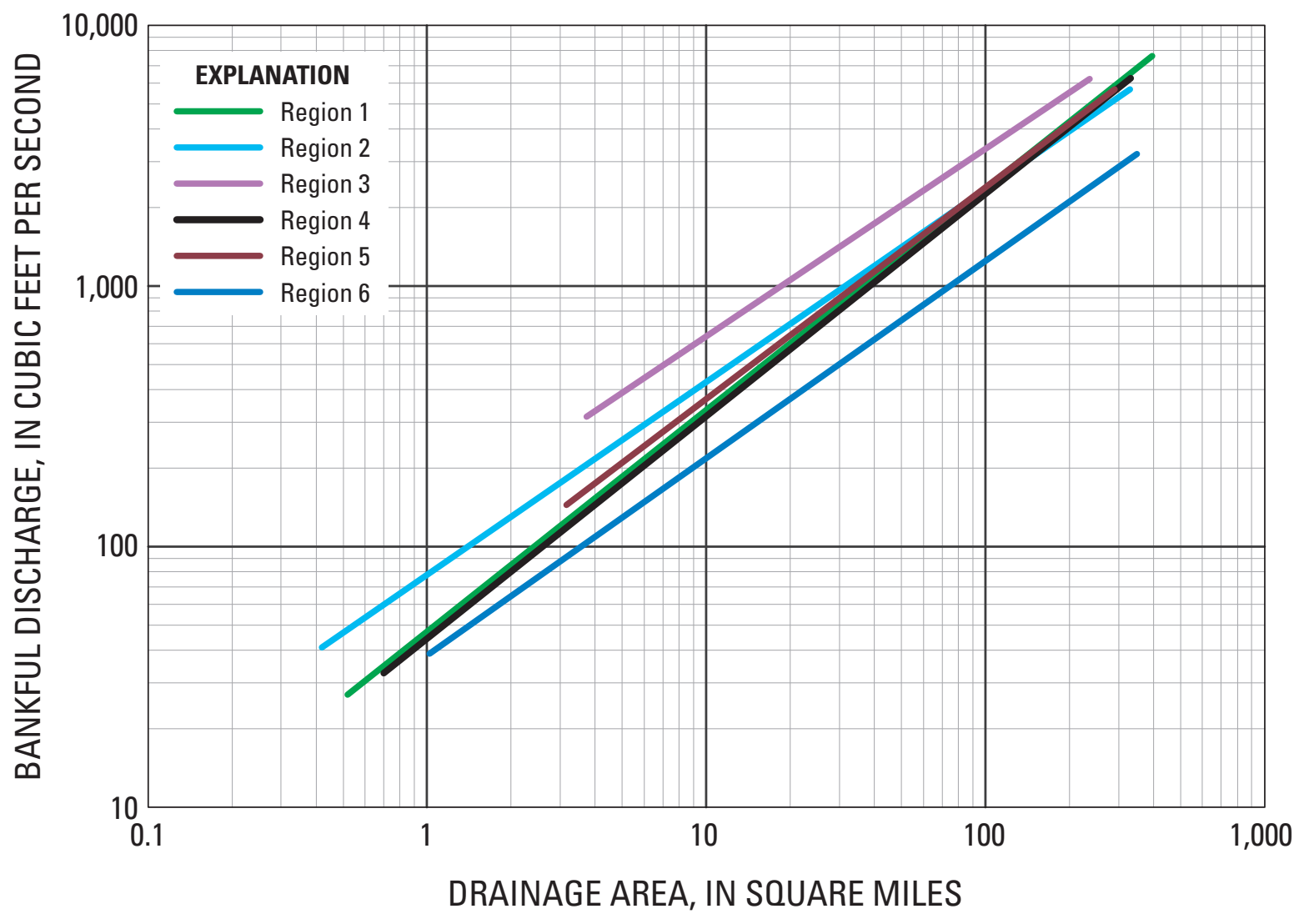

Figure 8. Bankfull discharge as a function of drainage area for six new hydrologic regions in New York State. 
Table 9. Regression equations for estimating bankfull discharge (in cubic feet per second) in unregulated streams in New York State, stratified by new hydrologic regions.

[DA, drainage area in square miles; $\mathrm{R}^{2}$, coefficient of determination]

\begin{tabular}{ccccc}
\hline Hydrologic region & $\begin{array}{c}\text { Number of } \\
\text { streamflow-gaging } \\
\text { stations } \\
\text { surveyed }\end{array}$ & Regression equation & $\begin{array}{c}\text { Standard error } \\
\text { of estimate } \\
\text { (percent) }\end{array}$ & $\mathbf{R}^{2}$ \\
\hline 1 & 17 & $47.0 \mathrm{DA}^{0.850}$ & 49 & 0.94 \\
2 & 16 & $77.9 \mathrm{DA}^{0.739}$ & 47 & .90 \\
3 & 10 & $122.4 \mathrm{DA}^{0.719}$ & 67 & .73 \\
4 & 15 & $44.3 \mathrm{DA}^{0.853}$ & 34 & .97 \\
5 & 12 & $56.8 \mathrm{DA}^{0.812}$ & 52 & .88 \\
6 & 12 & $38.2 \mathrm{DA}^{0.756}$ & 37 & .95 \\
\hline
\end{tabular}

Table 10. Similarities in bankfull discharge relations for 82 streamflow-gaging stations surveyed in six new hydrologic regions in New York State. Statistically similar relations, indicated by matching letters, are based on ANOVA analysis of the slopes and intercepts of regression lines having $p$-values greater than or equal to 0.05 .

\begin{tabular}{|c|c|c|c|c|c|c|c|c|c|c|}
\hline Hydrologic region & Intercept & Slope & & & ies & ful c & & & & \\
\hline 1 & 47.0 & 0.850 & A & B & $\mathrm{C}$ & & & & & \\
\hline 2 & 77.9 & .739 & A & & & $\mathrm{D}$ & $\mathrm{E}$ & F & & \\
\hline 3 & 122.4 & .719 & & & & D & & & G & \\
\hline 4 & 44.3 & .853 & & B & & & E & & & $\mathrm{H}$ \\
\hline 5 & 56.8 & .812 & & & $\mathrm{C}$ & & & $\mathrm{F}$ & $\mathrm{G}$ & $\mathrm{H}$ \\
\hline 6 & 38.2 & .756 & & & & & & & & \\
\hline
\end{tabular}

recent years, investigators have attempted to improve regional curves by stratifying bankfull-discharge data by variables such as mean annual runoff (Miller and Davis, 2003), Rosgen stream type (Rosgen, 1996), mean annual precipitation (Lawlor, 2005), physiographic province (Keaton and others, 2005), ecoregion (Castro and Jackson, 2001), and percent of carbonate bedrock (Chaplin, 2005). This investigation examined how stratifying data by mean annual runoff, Rosgen stream type, and slope affected relations between drainagearea size and bankfull discharge in New York.

\section{Stratifying by Mean Annual Runoff}

Bankfull-discharge and channel-characteristics data were stratified by mean annual runoff (MAR) to evaluate if regional relations could be improved by grouping together streams with similar precipitation patterns and basin characteristics that influence runoff amount. MAR is equal to precipitation minus evapotranspiration (Randall, 1996) and is expressed as the ratio of mean annual discharge to drainage area, in cubic feet per second per square mile $\left[\left(\mathrm{ft}^{3} / \mathrm{s}\right) / \mathrm{mi}^{2}\right]$ (Miller and Davis, 2003). MAR accounts for precipitation and basin characteristics affecting runoff volume (for example, slope, imperviousness, and evapotranspiration) and is normalized by drainage area to enable comparison between streams of different sizes (Miller and Davis, 2003; Randall, 1996). MAR data for streams in New York State are available from two sources: continuous-record streamflow-gaging stations and a map prepared by Randall (1996), which used records of streamflow and precipitation to estimate the location of MAR contours. Of the 82 streamflow-gaging stations surveyed for this investigation, only 32 were active continuous-record stations with up-to-date MAR data; the MAR at the remaining 50 stations was estimated from the Randall (1996) map. The accuracy of estimated MAR values was limited by (1) the use of precipitation and streamflow data from 1951 to 1980, which is not representative of recent trends towards increased runoff and decreased evapotranspiration (Randall, 1996), and (2) the fact that most precipitation and streamflow-gaging stations are in valleys - this lack of data in mountainous regions may cause precipitation and evapotranspiration to 


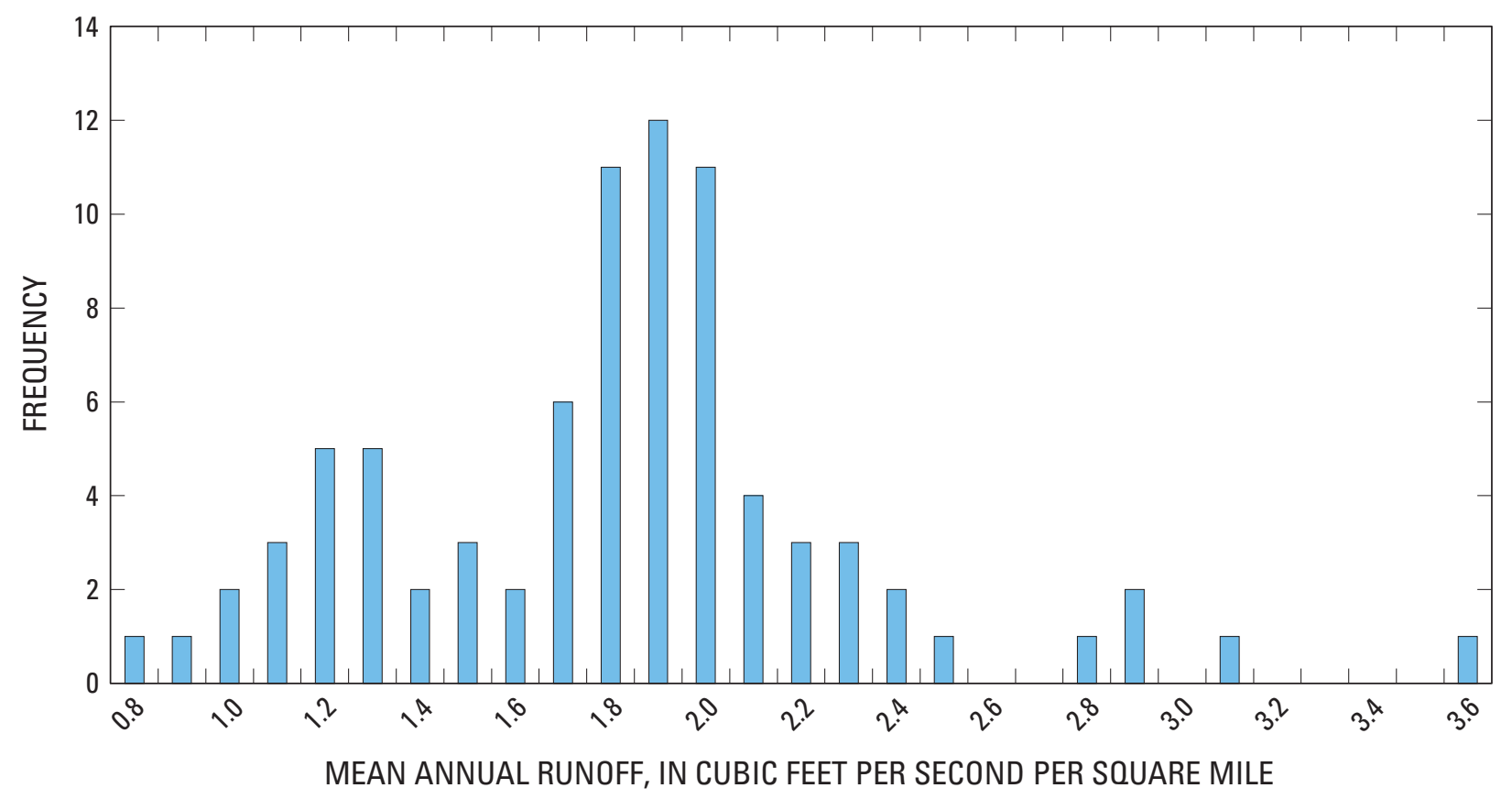

Figure 9. Histogram analysis of mean annual runoff distribution at 82 streamflow-gaging stations in New York State.

be underestimated in high-relief areas such as the Catskills (regions 4 and 4a, fig. 1) and the Adirondacks (regions 1 and 2, fig. 1) (Randall, 1996).

Estimates of MAR at the 82 streamflow-gaging stations ranged from 0.8 to $3.6\left(\mathrm{ft}^{3} / \mathrm{s}\right) / \mathrm{mi}^{2}$ (appendix 1) and had a roughly bell-shaped distribution with the majority of the streamflow-gaging stations having a MAR between 1.8 and $2.0\left(\mathrm{ft}^{3} / \mathrm{s}\right) / \mathrm{mi}^{2}$ (fig. 9). This distribution suggested that stratifying streamflow-gaging stations into low (0.8 to $\left.1.75\left(\mathrm{ft}^{3} / \mathrm{s}\right) / \mathrm{mi}^{2}\right)$, moderate (1.76 to $\left.2.04\left(\mathrm{ft}^{3} / \mathrm{s}\right) / \mathrm{mi}^{2}\right)$, and high (2.05 to $\left.3.63\left(\mathrm{ft}^{3} / \mathrm{s}\right) / \mathrm{mi}^{2}\right)$ MAR categories would be appropriate.

The relations stratified by MAR indicate that bankfull discharge at the study sites is strongly related with MAR and that these relations differ across the three classes (fig. 10). Stream sites with high MARs have high bankfull discharges, sites with moderate MARs have moderate bankfull discharges, and sites with low MARs have low bankfull discharges for streams of the same drainage-area size (fig. 10). Examination of the $\mathrm{R}^{2}$ values and standard errors of estimate (table 11) shows that standard errors of estimate and $\mathrm{R}^{2}$ values for the three MAR models are usually similar to those from the hydrologic-region models (table 1). The only exception to this is the slightly lower standard error of estimate for streamflowgaging stations with MAR values of $2.05-3.63\left(\mathrm{ft}^{3} / \mathrm{s}\right) / \mathrm{mi}^{2}$ (table 11). This exception may be because of the 18 sites included in this model, 15 sites have elevations of $900 \mathrm{ft}$ or more above NAVD 88 and are therefore in areas where lack of precipitation and evapotranspiration data may cause the MAR to be underestimated (Randall, 1996); also 7 sites are in the Catskill Mountain region where a recent investigation found that mean precipitation and runoff showed increasing trends from 1952 to 2005 (Burns and others, 2007).

These results indicate a positive relation between MAR and bankfull discharge and suggest that MAR models are useful tools for the verification of bankfull discharge to drainage-area size relations. A previous investigation by Miller and Davis (2003) showed that stratifying by MAR improved regional relations in hydrologic regions with highly variable relief and precipitation. However, ANOVA analysis shows that there are no statistically significant differences in two of the three MAR models (table 12). Therefore, although MAR can be a useful tool for the verification of bankfull discharge to drainage-area relations, it is important to use these models with caution at streams that do not have continuous-record streamflow-gaging stations or that are located at elevations greater than $900 \mathrm{ft}$ above NAVD 88.

\section{Stratifying by Rosgen Stream Type}

Bankfull-discharge data was stratified by Rosgen stream type to evaluate if regional relations could be improved by grouping streams with similar channel shapes (width/ depth ratios), gradients, plan views, and meander geometries together (Rosgen, 1994). The Rosgen classification system (Rosgen, 1996) categorizes streams on the basis of channel morphology to provide consistent, quantitative descriptions 


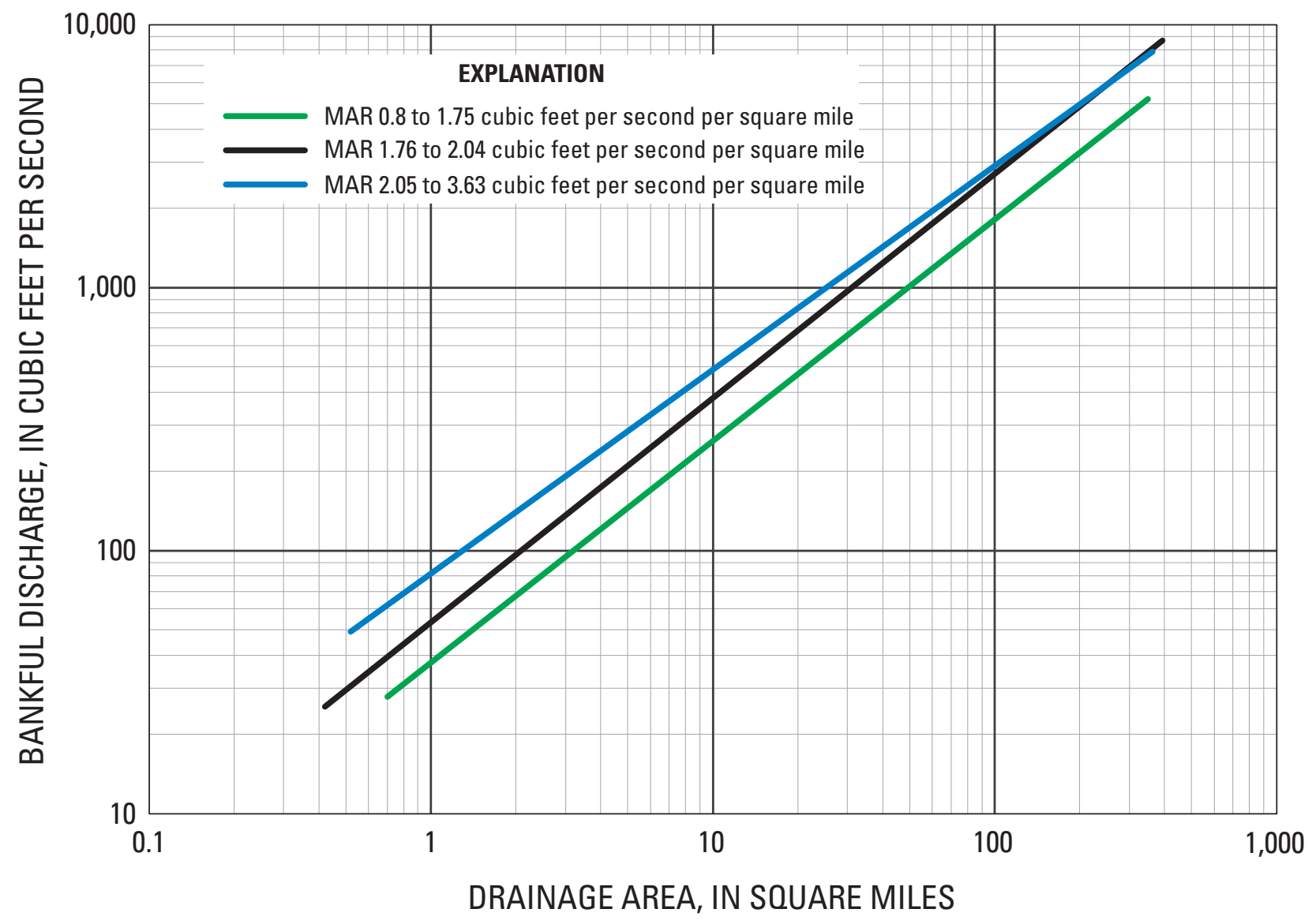

Figure 10. Bankfull discharge as a function of drainage area stratified by mean annual runoff (MAR).

Table 11. Regression equations for estimating bankfull discharge (in cubic feet per second) as a function of drainage area, stratified by mean annual runoff.

[MAR, mean annual runoff; $\left.\left(\mathrm{ft}^{3} / \mathrm{s}\right) / \mathrm{mi}^{2}\right)$, cubic feet per second per square mile; DA, drainage area in square miles; $\mathrm{R}^{2}$, coefficient of determination]

\begin{tabular}{ccccc}
\hline $\begin{array}{c}\text { MAR range } \\
\left(\mathbf{f t}^{\mathbf{3}} \mathbf{s} \mathbf{s} / \mathbf{m i}^{\mathbf{2}}\right)\end{array}$ & $\begin{array}{c}\text { Number of } \\
\text { streamflow-gaging } \\
\text { stations }\end{array}$ & Regression equation & $\begin{array}{c}\text { Standard error } \\
\text { of estimate } \\
\text { (percent) }\end{array}$ & $\mathbf{R}^{\mathbf{2}}$ \\
\hline $0.8-1.75$ & 30 & $37.6 \mathrm{DA}^{0.842}$ & 43 & 0.93 \\
$1.76-2.04$ & 34 & $53.3 \mathrm{DA}^{0.852}$ & 44 & .93 \\
$2.05-3.63$ & 18 & $81.8 \mathrm{DA}^{0.775}$ & 64 & .88 \\
\hline
\end{tabular}


Table 12. Similarities in bankfull-discharge relations, grouped by MAR range, for 82 streamflow-gaging stations surveyed in New York State. Statistically similar relations, indicated by matching letters, are based on ANOVA analysis of the slopes and intercepts of regression lines having $p$-values greater than or equal to 0.05 .

\begin{tabular}{cccc}
\hline MAR Range & Intercept & Slope & Similarities in bankful discharge \\
\hline $0.8-1.75$ & 37.6 & 0.842 & \\
$1.76-2.04$ & 53.3 & .852 & $\mathrm{~A}$ \\
$2.05-3.63$ & 81.8 & .775 & $\mathrm{~A}$ \\
\hline
\end{tabular}

of stream condition (Harman and Jennings, 1999). Stream reaches are divided into seven major stream-type categories that differ in entrenchment, gradient, width/depth ratio, and sinuosity (Rosgen, 1994). Within each major category are six additional types delineated by dominant channel materials from bedrock to silt/clay along a continuum of gradient ranges (Rosgen, 1994). A detailed explanation of the procedure used to classify streams in this study can be found in the individual hydrologic region reports (Miller and Davis, 2003; Westergard and others, 2005; Mulvihill and others, 2005, 2006, 2007; Mulvihill and Baldigo, 2007); the classification of each reach is in appendix 1, and the classification of each cross section is in appendix 2 .

Rosgen stream type was selected as a stratification variable because it was initially hypothesized that grouping geomorphically similar streams together would improve regional relations. This did not work as well as anticipated because (1) 17 reaches had to be eliminated from the analysis because multiple stream types were present and the Rosgen stream type that most accurately represented the geomorphic characteristics of the reach could not be determined (streamflow-gaging stations eliminated from the analysis are indicated by footnote 11 in appendix 1), (2) of the remaining reaches, 44 were type $\mathrm{C}, 12$ were type B, 4 were type E, and 5 were type $\mathrm{F}$ (table 13 and appendix 1), and (3) all the E-type streams were small (drainage area less than $10 \mathrm{mi}^{2}$; fig. 11) and all the F-type streams were large (drainage area greater than $30 \mathrm{mi}^{2}$; fig. 11); thus, the number of streams to which these models can be applied is somewhat limited.

Very few obvious differences are seen in models for the relation between bankfull discharge and drainage-area size in B, C, and F type streams (fig. 11). This was confirmed by ANOVA analysis which shows that there are no statistically significant differences between $\mathrm{B}$ and $\mathrm{F}$ or $\mathrm{F}$ and $\mathrm{C}$ type streams (table 14). In general, the Rosgen stream-type models have higher standard errors of estimate and lower $\mathrm{R}^{2}$ values (table 13) than the hydrologic-region models (table 1). These results indicate that (1) using Rosgen stream type to stratify bankfull discharge and channel characteristics usually does not improve regional relations, and (2) the application of the Rosgen stream-classification system is limited by a lack of guidance for cases where measurements yield nonunique solutions (multiple stream classes; Roper and others, 2008).

\section{Stratifying by Water-Surface Slope}

Previous investigations found water-surface slope to be a good explanatory variable in multiple linear regression equations predicting the magnitude and frequency of flood flows (Lumia, 1991; Lumia and others, 2006) and bankfull discharge (Sherwood and Huitger, 2005). Other studies (Emmett and Wolman, 2001; Grant and others, 1990; Kilpatrick and Barnes, 1964; Lisle, 1987) found that the recurrence interval of bankfull discharge tends to increase with an increase in channel slope (Sherwood and Huitger, 2005), although analysis of the 82 streams surveyed in this investigation did not reveal this relation. The relation between bankfull discharge and slope may be the result of several factors. First, bed features (pools, riffles, rapids, cascades, and steps) are consistently found to be related to channel slope (Rosgen, 1994). Second, high-gradient streams may tend to be more entrenched than lower gradient streams, thus affording them greater conveyance within the channel and, as a result, less frequent overbank flooding (Sherwood and Huitger, 2005). Third, the coarse bed material generally associated with high-gradient streams will tend to have higher entrainment thresholds and may require less frequent floods of greater discharge and velocity to cause movement of appreciable quantities of bed material (Sherwood and Huitger, 2005).

The slopes at the 82 study reaches (appendix 1) were mostly moderately low to very low, which limits the ability to stratify and assess bankfull-discharge relations by this factor. Histogram analysis of slope frequency distribution shows that streamflow-gaging stations with gentle slopes are much more common than streamflow-gaging stations with steep slopes (fig. 12). Streamflow-gaging stations were grouped into four slope range categories: $<0.006,0.006$ to $0.014,0.015$ to 0.025 , and 0.026 to 0.074 (table 15 and fig. 13). In the five high gradient streams, average standard errors of estimate are low and the $\mathrm{R}^{2}$ values are high, suggesting that slope is an important variable in bankfull discharge to drainage-area size relations in high relief areas (table 15). However, in the 11 streams with moderate slopes of 0.015 to 0.025 , the standard error of estimate is high and the $\mathrm{R}^{2}$ is low (table 15), suggesting that factors other than slope are affecting drainage-area size to bankfull discharge relations in these streams. Most of the streams surveyed had slopes that were moderately low to very low; in these streams, the models created when data were stratified by slope yield 


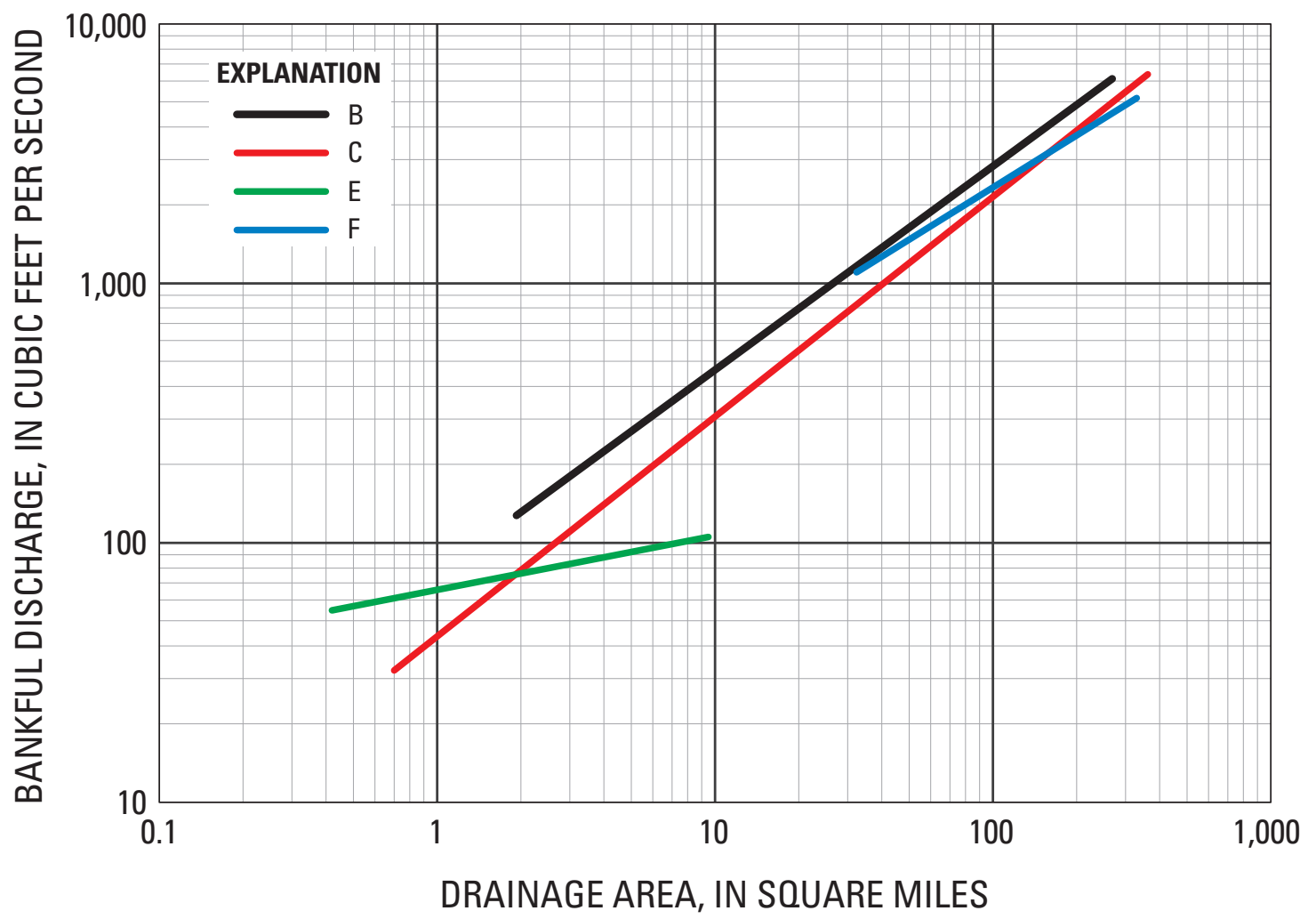

Figure 11. Bankfull discharge as a function of drainage area stratified by Rosgen stream type.

Table 13. Regression equations for estimating bankfull discharge (in cubic feet per second) as a function of drainage area, stratified by Rosgen stream type.

[DA, drainage area in square miles; $\mathrm{R}^{2}$, coefficient of determination]

\begin{tabular}{|c|c|c|c|c|}
\hline $\begin{array}{c}\text { Rosgen } \\
\text { stream type }\end{array}$ & $\begin{array}{c}\text { Number of } \\
\text { streamflow-gaging } \\
\text { stations }\end{array}$ & $\begin{array}{c}\text { Regression } \\
\text { equation }\end{array}$ & $\begin{array}{l}\text { Standard error } \\
\text { of estimate } \\
\text { (percent) }\end{array}$ & $\mathbf{R}^{2}$ \\
\hline B & 12 & $75.9 \mathrm{DA}^{0.784}$ & 56 & 0.89 \\
\hline $\mathrm{C}$ & 44 & $43.6 \mathrm{DA}^{0.846}$ & 48 & .89 \\
\hline $\mathrm{E}$ & 4 & $65.6 \mathrm{DA}^{0.211}$ & 35 & .51 \\
\hline $\mathrm{F}$ & 5 & $109.1 \mathrm{DA}^{0.665}$ & 43 & .82 \\
\hline
\end{tabular}


Table 14. Similarities in bankfull-discharge relations, grouped by Rosgen stream type, for 82 streamflow-gaging stations surveyed in in New York State. Statistically similar relations, indicated by matching letters, are based on ANOVA analysis of the slopes and intercepts of regression lines having $p$-values greater than or equal to 0.05 .

\begin{tabular}{|c|c|c|c|c|}
\hline $\begin{array}{c}\text { Rosgen } \\
\text { stream type }\end{array}$ & Intercept & Slope & \multicolumn{2}{|c|}{ Similarities in bankfull discharge } \\
\hline B-type & 75.9 & 0.784 & $\mathrm{~A}$ & \\
\hline E-type & 65.6 & .211 & & \\
\hline F-type & 109.1 & .665 & $\mathrm{~A}$ & B \\
\hline
\end{tabular}

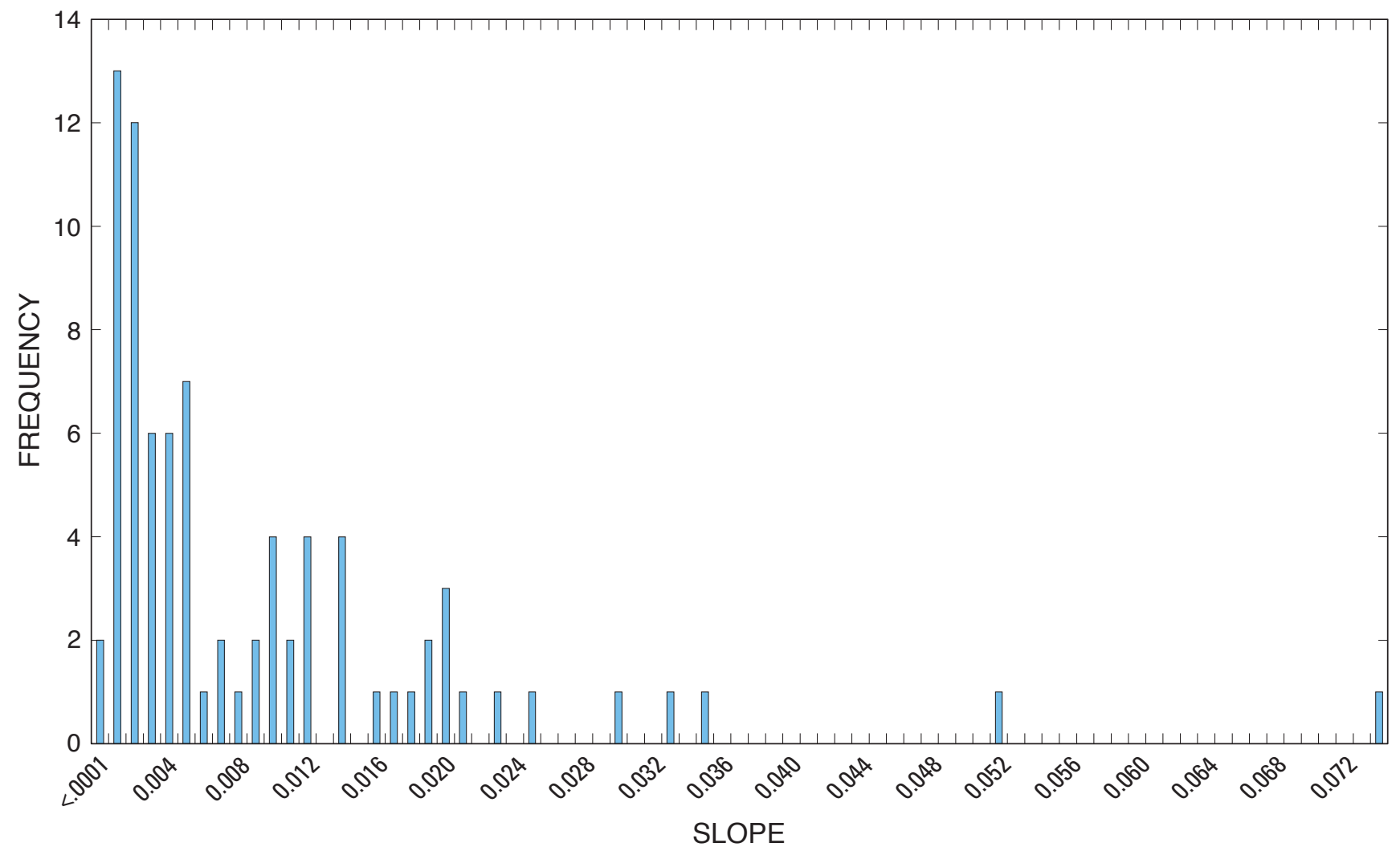

Figure 12. Histogram analysis of slope distribution at 82 streamflow-gaging stations in New York State. 
Table 15. Regression equations for estimating bankfull discharge (in cubic feet per second) as a function of drainage area, stratified by water-surface slope.

[DA, drainage area in square miles; $\mathrm{R}^{2}$, coefficient of determination; $<$, less than]

\begin{tabular}{lcccr}
\hline Slope range & $\begin{array}{c}\text { Number of } \\
\text { streamflow-gaging } \\
\text { stations }\end{array}$ & $\begin{array}{c}\text { Regression } \\
\text { equation }\end{array}$ & $\begin{array}{c}\text { Standard error } \\
\text { of estimate } \\
\text { (percent) }\end{array}$ & $\begin{array}{c}\mathbf{R}^{2} \\
48\end{array}$ \\
\hline$<0.006$ & 46 & $31.3 \mathrm{DA}^{0.920}$ & 50 & .89 \\
$0.006-0.014$ & 20 & $72.6 \mathrm{DA}^{0.803}$ & 70 & .43 \\
$0.015-0.025$ & 11 & $81.4 \mathrm{DA}^{0.549}$ & 21 & .97 \\
$0.026-0.074$ & 5 & $48.2 \mathrm{DA}^{0.854}$ & & \\
\hline
\end{tabular}

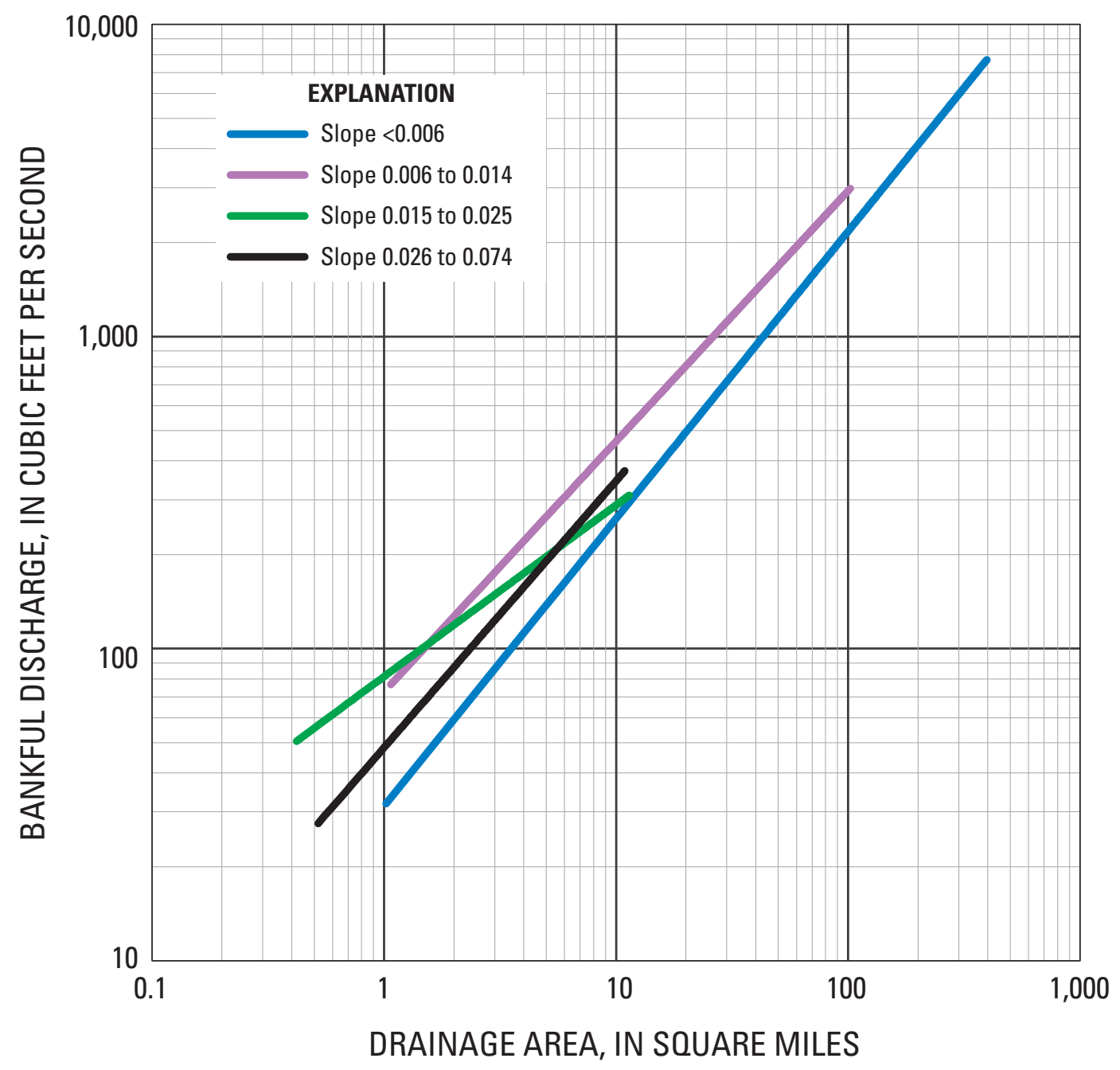

Figure 13. Bankfull discharge as a function of drainage area stratified by water-surface slope. 
Table 16. Similarities in bankfull -discharge relations, grouped by water-surface slope range for 82 streamflow-gaging stations surveyed in in New York State. Statistically similar relations, indicated by matching letters, are based on ANOVA analysis of the slopes and intercepts of regression lines having $p$-values greater than or equal to 0.05 .

$[<$, less than $]$

\begin{tabular}{cccccc}
\hline Slope range & Intercept & slope & \multicolumn{3}{c}{ Similarities in bankfull discharge } \\
\hline$<0.006$ & 31.3 & 0.920 & $\mathrm{~A}$ & & \\
$0.006-0.014$ & 72.6 & .803 & & $\mathrm{~B}$ & $\mathrm{C}$ \\
$0.015-0.025$ & 81.4 & .549 & $\mathrm{~A}$ & & $\mathrm{D}$ \\
$0.026-0.074$ & 48.2 & .854 & $\mathrm{~A}$ & $\mathrm{C}$ & $\mathrm{D}$ \\
\hline
\end{tabular}

average results (table 15). In most cases, the hydrologic-region models have slightly lower standard errors of estimate and slightly higher $\mathrm{R}^{2}$ values (table 1 ). Analysis of similarities in the four slope models found that the low slope $(<0.006)$ and high slope (0.026-0.074) models were statistically similar to each other (table 16), probably because only five streamflowgaging stations fell into the high slope range category (table 15). Therefore, although slope was a significant explanatory variable in the multiple linear regression equations delineating hydrologic-region boundaries (Lumia, 1991; Lumia and others, 2006), slope alone does not appear to explain most of the regional variation seen in bankfull discharge to drainagearea size relations.

\section{Comparison of New York State Equations to those Developed for Other Regions in the Northeast}

A premise of this investigation was that regional curves only provide reliable estimates of bankfull discharge and channel characteristics if the streamflow data used to construct them come from streams in the same hydrophysiographic region. Therefore, regional models should vary depending on local hydrology, soils, extent of development, climate, physiology, and geology. This hypothesis was tested by comparing the bankfull-discharge models for all of New York State, region 4, and region 7 to models for southeast Pennsylvania (Dunne and Leopold, 1978), Vermont (Jaquith and Kline, 2001), Streams in noncarbonate settings in Pennsylvania and Maryland (Chaplin, 2005), and southern Ontario (Annable, 1996) (fig. 14). The New York statewide model is almost exactly the same as the models for southeast Pennsylvania and Pennsylvania and Maryland (fig. 14), and the region 7 model (south of Lake Ontario; fig. 1) is almost exactly the same as the model for southern Ontario (fig. 14). However, models for region 4 and Vermont clearly show unique relations between bankfull discharge and drainage area that are not seen elsewhere among the Northeast models that were evaluated (fig. 14). ANOVA analysis confirmed that the Southern Ontario model was statistically similar to region 7 , and that the New
York statewide model was statistically similar to Southeast Pennsylvania, and Maryland, Southern Ontario, and Vermont (table 17). The only unique model was region 4 (table 17).

Although the pooled New York (statewide) model does not define bankfull discharge as accurately as regional models do, its similarity to the eastern United States model presented by Dunne and Leopold (1978) is evident (fig. 14). This result suggests that regionalized bankfull discharge to drainage-area size models do not substantially improve model utility. Another study that created a unified model using data from 204 natural-flowing streams in five states in the northeastern United States had similar results (Bent, 2006). However, comparing bankfull-discharge estimates from the New York State regional models to estimates from the Dunn and Leopold model of southeast Pennsylvania found that predictions of bankfull discharge from the two models differ by 10 to 76 percent in streams with drainage areas of $5 \mathrm{mi}^{2}$, by 7 to 87 percent in streams with drainage areas of $20 \mathrm{mi}^{2}$, by 11 to 94 percent in streams with drainage areas of $50 \mathrm{mi}^{2}$, and by 7 to 100 percent in streams with drainage areas of $100 \mathrm{mi}^{2}$ (table 18). The greatest differences are for streams in regions 4 (41 to 45 percent, table 18 ) and 7 ( 76 to 100 percent, table 18 ). This result is not surprising because both of these curves plotted outside the 95-percent confidence-interval bound for the statewide model (fig. 3).

\section{Other Uses of Regional Curves}

Regional curves have been primarily used to confirm bankfull-channel characteristics in streams that do not have streamflow-gaging stations and to verify that chosen bankfull features at ungaged streams approximate the channel-forming stages found at stable reaches with long-term flow records and known return intervals (Rosgen, 1996, 1998b). The correct assignment of bankfull at ungaged reference reaches is critical to bankfull surveys and the accurate calculation of channel characteristics (and dimensionless ratios), which are used for natural-channel restoration designs and correct classification of stream reaches (Rosgen, 1994). Dozens of channel-design parameters rely on bankfull features that vary with stream type (class), drainage area, and valley type in a given hydrologic region. Several additional applications for regional curves 


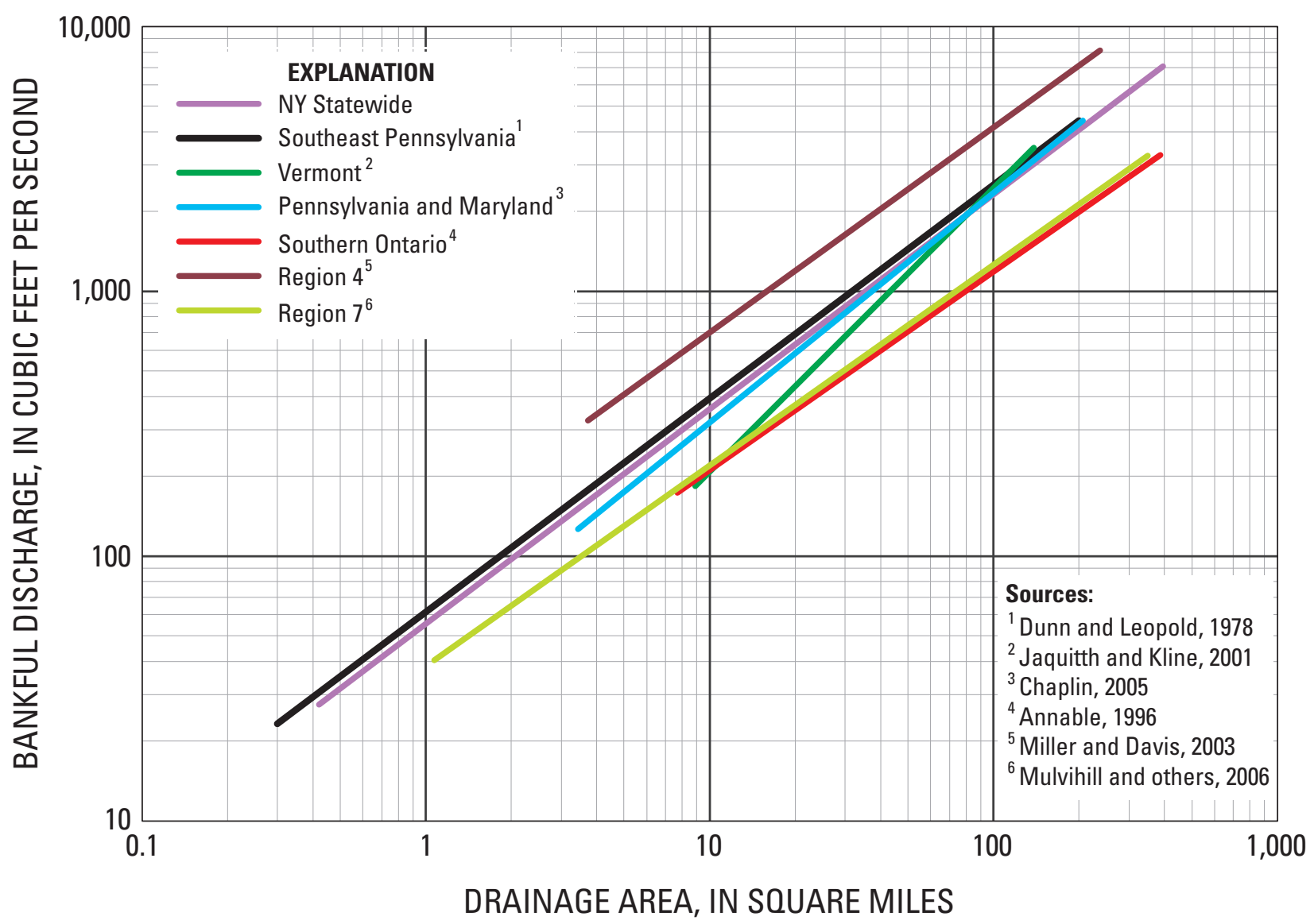

Figure 14. Bankfull discharge as a function of drainage area for all of New York State, regions 4 and 7 , and published curves for four other regions in the Northeast.

Table 17. Similarities in bankfull-discharge relations for the New York statewide model, regions 4 and 7 , and four other regions in the Northeast. Statistically similar relations, indicated by matching letters, are based on ANOVA analysis of the slopes and intercepts of regression lines having $p$-values greater than or equal to 0.05 .

$[\mathrm{N}$, number of observations]

\begin{tabular}{|c|c|c|c|c|c|c|c|c|c|c|c|}
\hline Geographic area & $\mathbf{N}$ & Intercept & Slope & & & Simil & $s$ in & full & $\operatorname{arge}$ & & \\
\hline Southern Ontario & $47^{1}$ & 35.9 & 0.752 & $\mathrm{~A}$ & B & $\mathrm{C}$ & & & & & \\
\hline Region 7 & 10 & 37.1 & .765 & A & & & & & & & \\
\hline Southeast Pennsylvania & 10 & 61.3 & .806 & & & & $\mathrm{D}$ & $\mathrm{E}$ & & & \\
\hline NewYork statewide & 82 & 55.4 & .810 & & $\mathrm{~B}$ & & $\mathrm{D}$ & & $\mathrm{F}$ & G & \\
\hline Vermont & 14 & 17.7 & 1.07 & & & $\mathrm{C}$ & & & & G & $\mathrm{H}$ \\
\hline
\end{tabular}

${ }^{1}$ Individual station data unavailable. 
have been proposed because of increased understanding of the complex relations among drainage area, bankfull discharge, channel characteristics, channel slope, velocity, flow resistance, channel stability, sediment size, and sediment load over the past decade. These include:

- Confirming whether proposed channel-restoration designs are reasonable.

- Estimating rough channel geometry for emergency stream repairs following floods and making recommendations regarding further assessment, evaluation, repair, replacement, or redesign.

- Determining if culvert, bridge, and stream ford designs will preserve stable bankfull geometry and prevent backwater situations and (or) sediment aggradation caused by over-wide or undersized channels.

- Using the extent to which existing channel characteristics depart from average values predicted by regional curves to gauge the stability of streams reaches.

- Providing estimates of bankfull-channel characteristics when reference-reach data are unavailable.

- Predicting the channel process in response to changes in flow regime resulting from modification of land use and land cover in the watershed.

- Developing stream-specific channelcharacteristics curves.

Users of design manuals referencing bankfull-channel characteristics and permitting agencies that need to approve stream-related projects in a timely manner have an immediate need for regional curves. Examples of design manuals that include bankfull-channel characteristics in design criteria are (1) the New York State Stormwater Design Manual, which requires that geomorphic assessments be done to determine bankfull-channel characteristics and related thresholds for channel stability that are then used as guidelines for distributed runoff control (Center for Watershed Protection, 2003), (2) the New York State Standards and Specifications for Erosion and Sediment Control, which requires that when brush mattresses are being used to control erosion the brush be placed up the bank to the bankfull elevation (New York State Soil and Water Conservation Committee, 2005), and (3) the Federal guidelines for the design for fish passage at road crossings, which use bankfull width as a design parameter (Hotchkiss and Frei, 2007). Regional curves could also be used by the New York State Coastal Zone Management Program and the Coastal Nonpoint Pollution Control Program to further their mission of reducing or mitigating sources of nonpoint pollution and restoring the in-stream and riparian habitat and water quality associated with modified streams. Inclusion of regional curves in the analysis of stream and watershed-related data from New York State Coastal Nonpoint areas would assist in characterizing the stability and biological condition of streams in the coastal watersheds that cover over 60 percent of the State.

Permitting and funding agencies can use regional curves to ensure that proposed plans for road, bridge and culvert design, stream-habitat improvement, gravel removal, channel modification, flood control, farmland and streambank stabilization, and nutrient and sediment reductions consider the influence of local precipitation, runoff, soil depths, elevations, surface slopes, and channel geomorphology when estimating bankfull discharges and related channel dimensions. Additional applications of regional models include prioritizing remediation projects by assessing the extent to which current in-stream conditions deviate from the channel characteristics predicted by regional models and assisting permitting agencies in deciding if the channel characteristics in proposed remediation designs are representative of those typically found in natural, undisturbed channels near the project site.

Regional curves may also be used to make rough estimates of channel dimensions during emergency situations where rapid responses to flooding and flood damage are needed. For example, flood-induced channel erosion, overwidening, incision, or aggradation commonly requires emergency instream stabilization, excavation, or filling to facilitate bridge and culvert replacement, to reopen roads, and (or) to protect private property and public infrastructure. Usually emergency-response practices such as pushing gravel into berms; constructing long sections of rock walls; over-widening for flood conveyance; removing riparian trees; digging straight, narrow, or deep channels; and flood-plain filling are used with little consideration of appropriate channel and flood-plain characteristics. Using regional curves to correctly size channels during post-flood reconstruction, repair, and stabilization can greatly reduce final restoration expenditures by avoiding the costs associated with reimporting sediment that was removed during erroneous channel oversizing. Regional curves provide a calibrated set of localized data that could be used to provide guidance during emergency stabilization and repair by providing a quick reference of appropriate channel characteristics, though additional expertise would still be needed to determine channel gradient, material sizes, and flood-plain dimensions. Regional curves have been used this way by the NYCDEP and DCSWCD during June 2006 flood-recovery efforts (New York City Department of Environmental Protection, 2007) and also by the DCSWCD during flood emergencies in June 2007. The advantage of using this method is that it should reduce the occurrence and severity of adverse destabilization caused by emergency actions and theoretically might speed channel recovery over traditional practices, such as over-widening.

It has been proposed that the application of regional curves could be facilitated by preparing maps that municipalities could use to quickly and easily determine the drainage areas and plan form geometry of their work sites and apply the appropriate regression equations, or by using 
Table 18. Comparison of bankfull-discharge estimates from New York regional models to estimates from the Dunn and Leopold (1978) regional model for southeast Pennsylvania.

$\left[\mathrm{mi}^{2}\right.$, square miles; $\mathrm{ft}^{3} / \mathrm{s}$, cubic feet per second]

\begin{tabular}{|c|c|c|c|c|}
\hline Hydrologic region & $\begin{array}{l}\text { Drainage area } \\
\qquad\left(\mathrm{mi}^{2}\right)\end{array}$ & $\begin{array}{l}\text { Bankfull discharge } \\
\left.\text { (ft } \mathrm{ft}^{3} / \mathrm{s}\right) \\
\text { from hydrologic region } \\
\text { equations (table 1) }\end{array}$ & $\begin{array}{l}\text { Bankfull discharge } \\
\qquad\left(\mathrm{ft}^{3} / \mathrm{s}\right) \\
\text { from Dunn and Leopold } \\
\text { regional model for } \\
\text { southeast Pennsylvania }\end{array}$ & $\begin{array}{c}\text { Difference } \\
\text { (in percent) } \\
\text { of hydrologic region } \\
\text { estimates to Dunn and } \\
\text { Leopold estimates }\end{array}$ \\
\hline 1 and 2 & 5 & 183 & 224 & 23 \\
\hline 3 & 5 & 250 & 224 & 10 \\
\hline $4 a$ & 5 & 147 & 224 & 53 \\
\hline 5 & 5 & 180 & 224 & 25 \\
\hline 6 & 5 & 186 & 224 & 21 \\
\hline 7 & 5 & 127 & 224 & 76 \\
\hline 1 and 2 & 20 & 593 & 686 & 16 \\
\hline 5 & 20 & 589 & 686 & 16 \\
\hline 6 & 20 & 598 & 686 & 15 \\
\hline 7 & 20 & 367 & 686 & 87 \\
\hline 1 and 2 & 50 & 1,291 & 1,435 & 11 \\
\hline 3 & 50 & 1,194 & 1,435 & 20 \\
\hline 4 & 50 & 2,478 & 1,435 & 42 \\
\hline $4 a$ & 50 & 1,401 & 1,435 & 2 \\
\hline 5 & 50 & 1,289 & 1,435 & 11 \\
\hline 5 & 100 & 2,334 & 2,509 & 7 \\
\hline 6 & 100 & 2,319 & 2,509 & 8 \\
\hline 7 & 100 & 1,257 & 2,509 & 100 \\
\hline
\end{tabular}


GIS technology to determine drainage areas and channel characteristics at specific locations. Another possible solution would be adding regional regression equations for bankfull discharge and channel characteristics to StreamStats, a USGS web-based tool that allows users to obtain streamflow statistics, drainage-basin characteristics, and other information for user-selected sites on streams (Ries and others, 2004).

\section{Limitations of Regional Curves}

An assumption made in this investigation that the bankfull discharge was within the 1- to 2-year recurrenceinterval range may be an oversimplification (Thorne and others, 1997), even though similar recurrence intervals have been obtained in other studies (Harman and Jennings, 1999; Rosgen, 1994). Channel characteristics associated with a $1-$ to 2 -year recurrence interval were used to aid in the identification of bankfull indicators during initial site inspections, but if the bankfull recurrence interval at a site was longer or shorter than that frequency, the bankfull channel could be incorrectly identified (White, 2001). The average bankfull recurrence interval for streams surveyed in New York State was 1.77 years, which is longer than the average 1.5 -year frequency predicted by Rosgen (1996) but still within the 1- to 2.5-year range predicted by Leopold (1994).

Another limiting factor in regional-curve development is the number of active USGS streamflow-gaging stations that meet selection criteria. This lack of appropriate gaging stations necessitated the use of 16 inactive streamflow-gaging stations, 17 containing more than 1 stream type, 3 with less than 10 years of record, 1 that was not operated by the USGS, and 1 that was in New Jersey. The following assumptions were made about inactive gaging stations: (1) the recurrence interval of bankfull discharge had not changed since the gaging station was last active, (2) the flow patterns of the gaging stations had not been significantly altered by floods, diversions, ground-water recharge, or changes in land use, and (3) three to five low- to medium-flow discharge measurements were adequate to accurately define a stage-to-discharge relation that could reliably be extended to determine a bankfull discharge. The data analysis for the 17 sites representing more than one stream type assumed that averaging measurements from cross sections of differing stream types provided an accurate measure of overall reach characteristics. The use of three sites that had been active for less than 10 years assumed that existing records were sufficient for field verification of bankfull stage; the actual recurrence interval of bankfull discharge will be recalculated when additional data become available.

Results were also limited by the number of streamflowgaging stations with small drainage areas. Only 16 streams with drainage areas less than $5.0 \mathrm{mi}^{2}$ and 3 with drainage areas less than $1.0 \mathrm{mi}^{2}$ were surveyed (appendix 1). This is a concern because channel-characteristics models show that bankfull-channel width, depth, and cross-sectional area are most variable in small channels (figs. 4, 5, and 6). Also, stream-restoration and habitat-improvement projects are usually implemented on small streams.

In some regions, it was necessary to survey streamflowgaging stations on streams that had sharp changes in channel slope and (or) no clearly identifiable bankfull indicators near the streamflow-gaging station. In these cases, calculating bankfull discharge by standard methods did not yield reasonable results and either a LOWESS smooth (5 gaging stations, appendix 1) or HEC-RAS analysis (17 gaging stations, appendix 1) was used instead. Bankfull discharges calculated by these alternative methods were presumed to be accurate if they had a 1- to 2-year recurrence interval, although it was not possible to verify this assumption.

Regional channel-characteristics equations can be more accurate than those representing an entire state or larger area in characterizing the bankfull features of reference reaches used for stream-restoration projects, enhancement of fish habitat, and the placement of in-stream and riparian structures (Castro and Jackson, 2001). However, the exclusive use of regional curves for sizing stream channels should be discouraged when time and resources permit more rigorous design methods using appropriate local data on reference-reach characteristics, sediment supply, and transport conditions. Also, it is important to remember that local conditions such as bedrock controls, human alterations, long-term beaver activity, and water withdrawals and impoundments must always be taken into account before final permitting and remediation decisions are made.

Though regional models of bankfull discharge and channel characteristics to drainage area relations can save time and money, users of these curves need to recognize their limitations and accept that these regression equations are designed only to provide estimates of bankfull-channel characteristics and discharges and are not intended to substitute for the field measurement and verification of bankfull-channel characteristics and streamflow (White, 2001).

\section{Summary}

Equations that relate bankfull discharge and channel characteristics (width, depth, and cross-sectional area) to the size of the drainage area at gaged stream sites are needed to predict bankfull discharge and channel characteristics at ungaged streams. These models are needed by Federal, state, and local agencies and engineering firms for verification of bankfull discharge and channel characteristics in stream classification, stability, restoration, and habitat improvement projects. This report seeks to increase understanding of the factors affecting bankfull discharge and channel characteristics to drainage-area size relations in New York State by providing an in-depth analysis of seven previously published regional bankfull-discharge and channel-characteristics curves. 
Stream-survey data and discharge records from 281 cross sections at 82 streamflow-gaging stations surveyed 1999-2006 were used in regression analyses to develop linear regression equations that relate drainage-area size to bankfull discharge and channel characteristics in eight hydrologic regions in New York State. The standard errors and $\mathrm{R}^{2}$ of these regional equations were compared to a pooled statewide model to quantify the extent to which regionalizing data improved the model accuracy. It was found that the standard error of estimate of the statewide equation is the same or slightly lower than most of the hydrologic region models, and five of the seven hydrologic region models have $\mathrm{R}^{2}$ values that are higher than the $\mathrm{R}^{2}$ of the statewide model.

Bankfull-discharge data were also stratified by mean annual runoff, Rosgen stream type, and slope in an attempt to further refine regional relations between bankfull discharge and drainage-area size. Results indicated that the utility of these data-stratification variables was somewhat limited by the lack of accurate and readily available data. Furthermore, in most cases, the hydrologic region models have lower standard errors of estimate and higher $\mathrm{R}^{2}$ values. This is not surprising because the hydrologic regions were delineated using multiple linear regression equations that accounted for significant explanatory variables such as slope, percent basin storage, mean annual precipitation, percent forested area, average main-channel elevation, and a basin-shape index.

This investigation also tested the hypothesis that bankfull-discharge and channel-characteristics equations are most accurate if derived from streams within an area of uniform hydrologic, climatic, and physiographic conditions. Models for all of New York State, region 4, and region 7 were compared to models for southeast Pennsylvania, Vermont, Pennsylvania and Maryland, and southern Ontario. Although ANOVA analysis found only one regional model to be statistically different, differences in bankfull-discharge estimates between the hydrologic-region models and the southeast Pennsylvania model could be as high as 100 percent. This study examined 18 models for bankfull discharge to drainage area relations and concluded that hydrologic-region models provide the most reliable estimates because regional boundaries were delineated using multiple linear regression equations that accounted for a combination of climatic, physiographic, and geologic characteristics that explain variations in streamflow patterns.

\section{Acknowledgments}

Thanks are extended to Daniel Davis and Elizabeth Reichheld (NYCDEP) for geomorphology training and for advice on survey and data analysis and methods of interpretation. We would also like to thank the NYCDEP, GCSWCD, and DCSWCD for providing some of the data presented herein. Thanks are also extended to numerous USGS and Cornell University personnel for assistance in the field.

\section{References Cited}

Annable, W.K., 1996, Morphologic relationships of rural watercourses in southern Ontario and selected field methods in fluvial geomorphology: Meadowvale, Ont., Ontario Ministry of Natural Resources, ISBN\# 0-7778-5113-X, $92 \mathrm{p}$.

Bent, G.C., 2006, Equations for estimating bankfull-channel geometry and discharge for streams in the northeastern United States in Proceedings of the Joint Federal Interagency Conference, Book of Abstracts, 3rd Federal Interagency Hydrologic Modeling Conference and 8th Federal Interagency Sedimentation Conference: Reno, Nev., April 2-6, 2006, p. 314.

Brunner, G.W., 1997, HEC-RAS River Analysis System user's manual: U.S. Army Corps of Engineers CPD-68, 205 p.

Burns, D.A., Klaus, Julian, and McHale, M.R., 2007, Recent climate trends and implications for water resources in the Catskill Mountain region, New York, USA: Journal of Hydrology, v. 336, p. 155-170.

Castro, J.M., and Jackson, P.L., 2001, Bankfull discharge recurrence intervals and regional hydraulic geometry relationships - Patterns in the Pacific Northwest, USA: Journal of the American Water Resources Association, v. 37, no. 5 , p. 1249-1262.

Center for Watershed Protection, 2003, New York State Stormwater Management Design Manual: Ellicott City, Md., Center for Watershed Protection, 416 p.

Chaplin, J.J., 2005, Development of regional curves relating bankfull-channel geometry and discharge to drainage area for streams in Pennsylvania and selected areas of Maryland: U.S. Geological Survey Scientific Investigations Report 2005-5147, 34 p.

Cinotto, P.J., 2003, Development of regional curves of bankfull-channel geometry and discharge for streams in the non-urban, Piedmont Physiographic Province, Pennsylvania and Maryland: U.S. Geological Survey Water-Resources Investigations Report 03-4014, 33 p.

Dalrymple, Tate, and Benson, M.A., 1968, Measurement of peak discharge by the slope-area method: U.S. Geological Survey Techniques of Water-Resources Investigations, book 3, chap. A2, 12 p.

Dudley, R.W., 2004, Hydraulic-geometry relations for rivers in coastal and central Maine: U.S. Geological Survey Scientific Investigations Report 2004-5042, 37 p.

Dunne, Thomas, and Leopold, L.B., 1978, Water in environmental planning: San Francisco, Calif., W.H. Freeman Co., 818 p. 
Emmett, W.W., and Wolman, M.G., 2001, Effective discharge and gravel-bed rivers: Earth Surface Processes and Landforms, v. 26, no. 13, p. 1369-1380.

Flynn, R.H., 2003, Development of regression equations to estimate flow durations and low-flow frequency statistics in New Hampshire streams: U.S. Geological Survey WaterResources Investigations Report 02-4298, 66 p.

Grant, G.E., Swanson, F.J., and Wolman, M.G., 1990, Pattern and origin of stepped-bed morphology in high-gradient streams, Western Cascades, Oregon: Geological Society of America Bulletin, v. 102, no. 3, p. 340-352.

Harman, W.A., and Jennings, G.D., 1999, River courseApplication of the Rosgen stream classification system to North Carolina: Raleigh, N.C., North Carolina Cooperative extension service, accessed October 5, 2002, at http://www. bae.ncsu.edu/programs/extension/wqg/sri/rv-crs2.pdf

Helsel, D.R., and Hirsch, R.M., 2002, Statistical methods in water resources: U.S. Geological Survey Techniques of Water-Resources Investigation, book 4, chap. A3, 523 p.

Hotchkiss, R.H., and Frei, C.M., 2007, Design for fish passage at roadway-stream crossings-Synthesis report: McLean, Va., Federal Highway Administration Publication No. FHWA-HIF-07-033, 280 p.

Jaquith, Shayne, and Kline, Michael, 2001, Vermont regional hydraulic geometry curves: River Management Program, Vermont Water Quality Division, accessed March 6, 2003, at http://www.anr.state.vt.us/dec/waterq/rivers/docs/ rv_hydraulicgeocurves.pdf

Jarrett, R.D., and Petsch, H.E., Jr., 1985, Computer program NCALC user's manual-Verification of Manning's roughness coefficient in channels: U.S. Geological Survey Water-Resources Investigations Report 85-4317, 27 p.

Johnson, P.A., and Heil, T.M., 1996, Uncertainty in estimating bankfull conditions: Journal of the American Water Resources Association, v. 32, no. 6, p. 1283-1291.

Keaton, J.N., Messinger, Terence, and Doheny, E.J., 2005, Development and analysis of regional curves for streams in the non-urban Valley and Ridge Physiographic Province, Maryland, Virginia, and West Virginia: U.S. Geological Survey Scientific Investigations Report 2005-5076, 109 p.

Kilpatrick, F.A., and Barnes, H.H., Jr., 1964, Channel geometry of Piedmont streams as related to frequency of floods: U.S. Geological Survey Professional Paper 422-E, p. E1-E10.

Kirby, William, 1981, Annual flood frequency analysis using U.S. Water Resources council guidelines (Program J407), chapter I, section C of WATSTORE user's guide: U.S. Geological Survey Open-File Report 76-435, 57 p.
Lawlor, S.M., 2005, Determination of channel-morphology characteristics, bankfull discharge, and various design-peak discharges in Western Montana: U.S. Geological Survey Scientific Investigations Report 2004-5263, 13 p.

Leopold, L.B., 1994, A view of the river: Cambridge, Mass., Harvard University Press, 290 p.

Leopold, L.B., and Maddock, Thomas, Jr., 1953, The hydraulic geometry of stream channels and some physiographic implications: U.S. Geological Survey Professional Paper 252, 56 p.

Leopold, L.B., Wolman, M.G., and Miller, J.P., 1964, Fluvial processes in geomorphology: San Francisco, Calif., W.H. Freeman and Co., 522 p.

Lisle, T.E., 1987, Overview-Channel morphology and sediment transport in steepland streams, in Beschta, R.L., Blinn, T., Grant, G.E., Swanson, F.J., and Ice, G.G., eds. Erosion and sedimentation in the Pacific Rim (Proceedings of the Corvallis Symposium, August 1987): Oslo, Norway, International Association of Hydrological Sciences Publication No. 165, p. 287-297.

Lumia, Richard, 1991, Regionalization of flood discharges for rural, unregulated streams in New York, excluding Long Island: U.S. Geological Survey Water-Resources Investigations Report 90-4197, 119 p.

Lumia, Richard, and Baevsky, Y.H., 2000, Development of a contour map showing generalized skew coefficients of annual peak discharges of rural, unregulated streams in New York, excluding Long Island: U.S. Geological Survey Water-Resources Investigations Report 2000-4022, 11 p.

Lumia, Richard, Freehafer, D.A., and Smith, M.J., 2006, Magnitude and frequency of floods in New York: U.S. Geological Survey Scientific Investigations Report 2006-5112, 152 p.

Miller, S.J., and Davis, Daniel, 2003, Identifying and optimizing regional relations for bankfull discharge and hydraulic geometry at USGS stream gage sites in the Catskill Mountains, N.Y.: New York City Department of Environmental Protection Technical Report, 24 p.

Mulvihill, C.I., Ernst, A.G., and Baldigo, B.P., 2005, Regionalized equations for bankfull discharge and channel characteristics of streams in New York State-Hydrologic Region 6 in the southern tier of New York: U.S. Geological Survey Scientific Investigations Report 2005-5100, 14 p., online only. 
Mulvihill, C.I., Ernst, A.G., and Baldigo, B.P., 2006, Regionalized equations for bankfull discharge and channel characteristics of streams in New York State-Hydrologic Region 7 in western New York: U.S. Geological Survey Scientific Investigations Report 2006-5075, 14 p., online only.

Mulvihill, C.I., Filopowicz, Amy, Coleman, Arthur, and Baldigo, B.P., 2007, Regionalized equations for bankfull discharge and channel characteristics of streams in New York State-Hydrologic Regions 1 and 2 in the Adirondack region of Northern New York: U.S. Geological Survey Scientific Investigations Report 2007-5189, 18 p., online only.

Mulvihill, C.I., and Baldigo, B.P., 2007, Regionalized equations for bankfull discharge and channel characteristics of streams in New York State-Hydrologic Region 3 east of the Hudson River: U.S. Geological Survey Scientific Investigations Report 2007-5227, 15 p., online only.

New York City Department of Environmental Protection, 2007, Filtration avoidance annual report for the period January 1 through December 31, 2006: Bureau of Water Supply, 170 p.

New York State Soil and Water Conservation Committee, 2005, New York State Standards and Specifications for Erosion and Sediment Control, 406 p.

Ott, R.L., and Longnecker, M.T., 2001, An introduction to statistical methods and data analysis (5th ed.): Duxbury Press, 1184 p.

Powell, R.O., Miller, S.J., Westergard, B.E., Mulvihill, C.I., Baldigo, B.P., Gallagher, A.S., and Starr, R.R., 2004, Guidelines for surveying bankfull channel geometry and developing regional hydraulic-geometry relations for streams of New York State: U.S. Geological Survey OpenFile Report 03-92, 26 p.

Randall, A.D., 1996, Mean annual runoff, precipitation, and evapotranspiration in the glaciated Northeastern United States, 1951-80: U.S. Geological Survey Open-File Report 96-395, 2 pls.

Ries, K.G., III, and Friesz, P.J., 2000, Methods for estimating low-flow statistics for Massachusetts streams: U.S. Geological Survey Water-Resources Investigations Report 00-4135, $81 \mathrm{p}$.

Ries, K.G., III, Steeves, P.A., Coles, J.D., Rea, A.H., and Stewart, D.W., 2004, StreamStats-A U.S. Geological Survey web application for stream information: U.S. Geological Survey Fact Sheet 2004-3115, 4 p.
Roper, B.B., Buffington, J.M., Archer, Eric, Moyer, Chris, and Ward, Mike, 2008, The role of observer variation in determining Rosgen stream types in Northeastern Oregon mountain streams: Journal of the American Water Resources Association, v. 44, no. 2, p. 417-427.

Rosgen, D.L., 1994, A classification of natural rivers: Catena, v. 22 , no. 3, p. 169-199.

Rosgen, D.L., 1996, Applied river morphology: Pagosa Springs, Colo., Wildland Hydrology Books, 385 p.

Rosgen, D.L., 1998a, River field book: Pagosa Springs, Colo., Wildland Hydrology Books, 390 p.

Rosgen, D.L., 1998b, The reference reach-A blueprint for natural channel design, in Hayes, D.F., ed., Proceedings ASCE Wetlands Engineering and River Restoration Conference, Denver, Colo., March 1998: American Society of Civil Engineers, 7 p.

Sherwood, J.M., and Huitger, C.A., 2005, Bankfull characteristics of Ohio streams and their relation to peak streamflows: U.S. Geological Survey Scientific Investigations Report 2005-5153, 38 p.

Statgraphics Plus for Windows, 1996, Advanced Regression Module Manual. Version 2: Rockville, Md., Manugistics, $307 \mathrm{p}$.

Szabo, C.O., Grover, J.S., and McInnes, S.K., 2006, Water resources data, New York, water year 2005, volume 3, Western New York: U.S. Geological Survey Water-Data Report NY-05-3, $454 \mathrm{p}$.

Thorne, C.R., Het, R.D., and Newson, M.D., 1997, Applied fluvial geomorphology for river engineering and management: Chichester, England, John Wiley and Sons, $376 \mathrm{p}$.

U.S. Geological Survey, 2006, Water resources data, New York, water year 2005, Eastern New York excluding Long Island: U.S. Geological Survey Water Data Report NY-05-1, 996 p.

U.S. Geological Survey, 2008, Regionalization of channel geomorphology characteristics for streams of New York State, excluding Long Island: accessed April 28, 2008, at http://ny.cf.er.usgs.gov/nyprojectsearch/projects/ 2457-A29-1.html

U.S. Water Resources Council, 1981, Guidelines for determining floodflow frequency: Hydrology Subcommittee Bulletin 17B, 28 p., appendix. 
Westergard, B.E., Mulvihill, C.I., Ernst, A.G., and Baldigo, B.P., 2005, Regionalized equations for bankfull discharge and channel characteristics of streams in New York StateHydrologic Region 5 in Central New York: U.S. Geological Survey Scientific Investigations Report 2004-5247, 16 p., online only.

White, K.E., 2001, Regional curve development and selection of a reference reach in the non-urban lowland sections of the Piedmont Physiographic Province, Pennsylvania and Maryland: U.S. Geological Survey Water-Resources Investigations Report 01-4146, $20 \mathrm{p}$.

Wolman, M.G., and Miller, J.P., 1960, Magnitude and frequency of forces in geomorphic processes: Journal of Geology, v. 68, p. 54-74. 


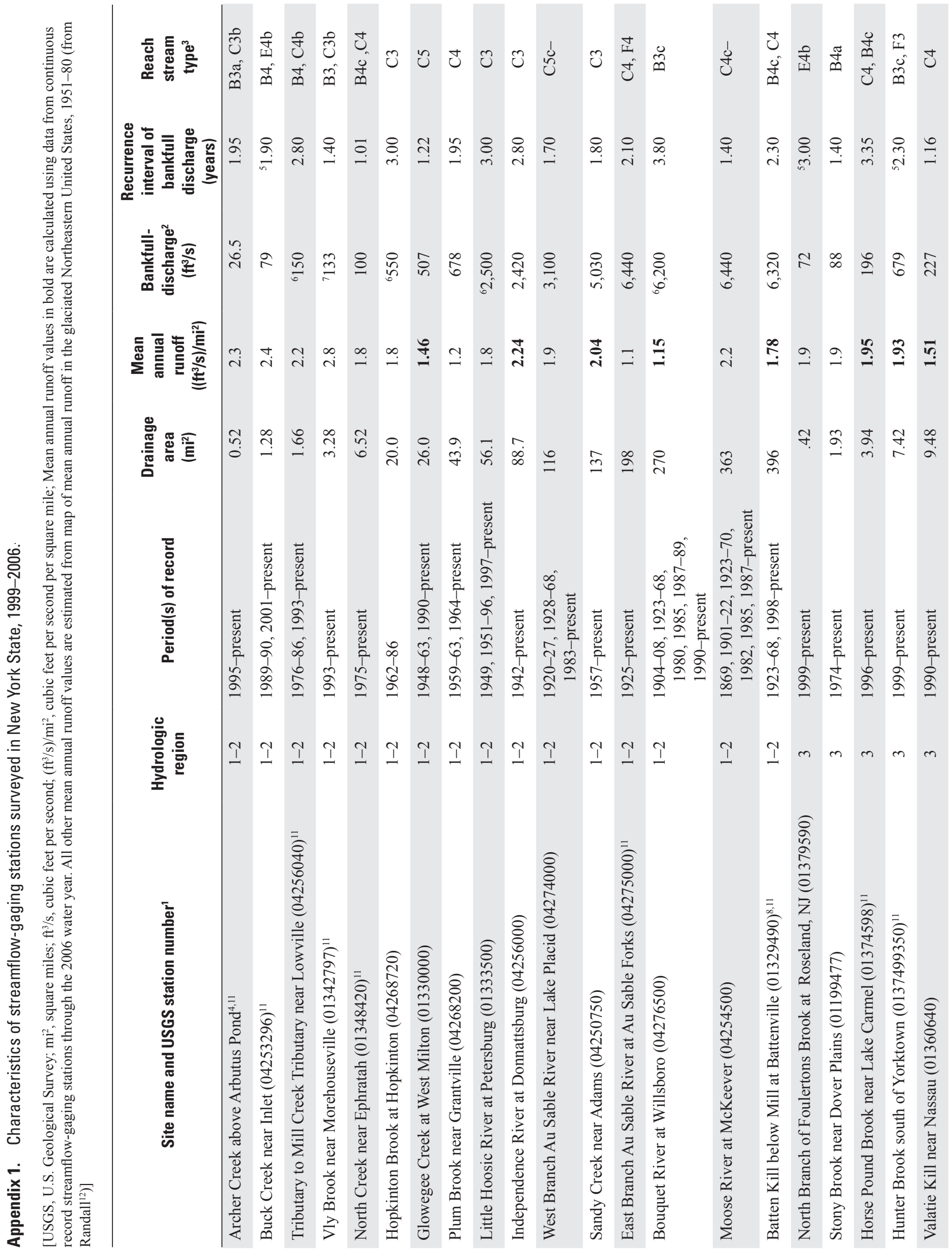




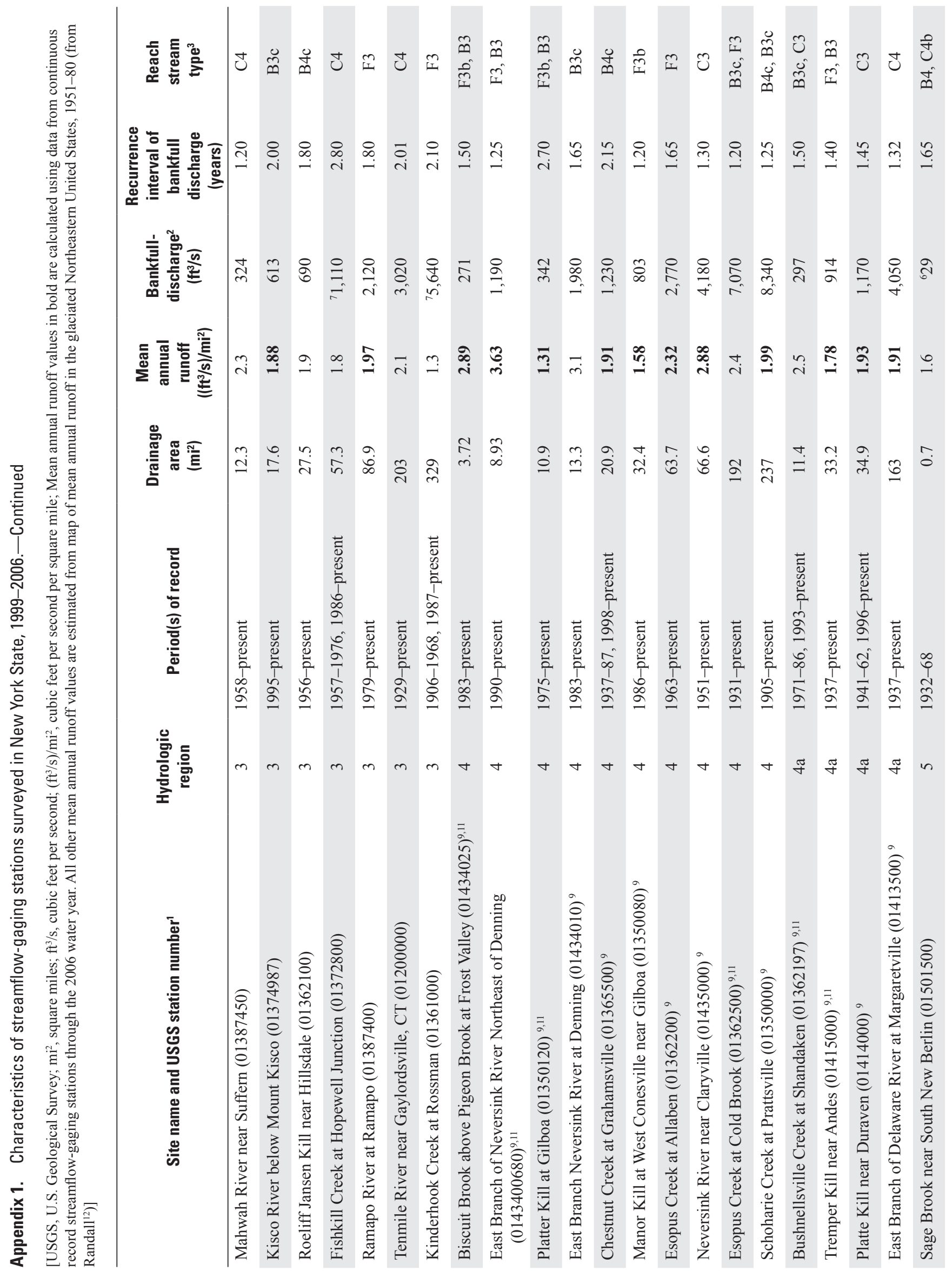




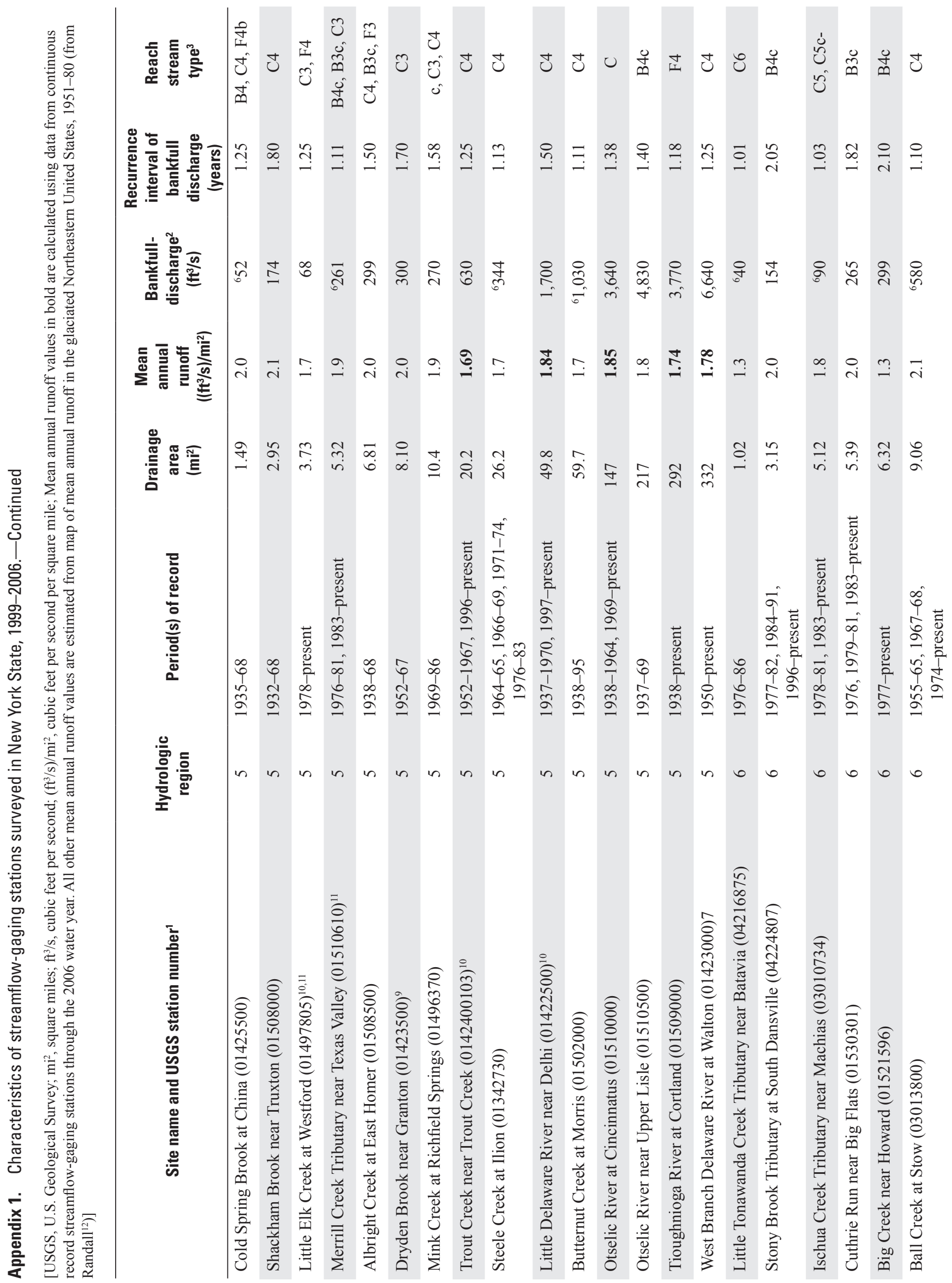




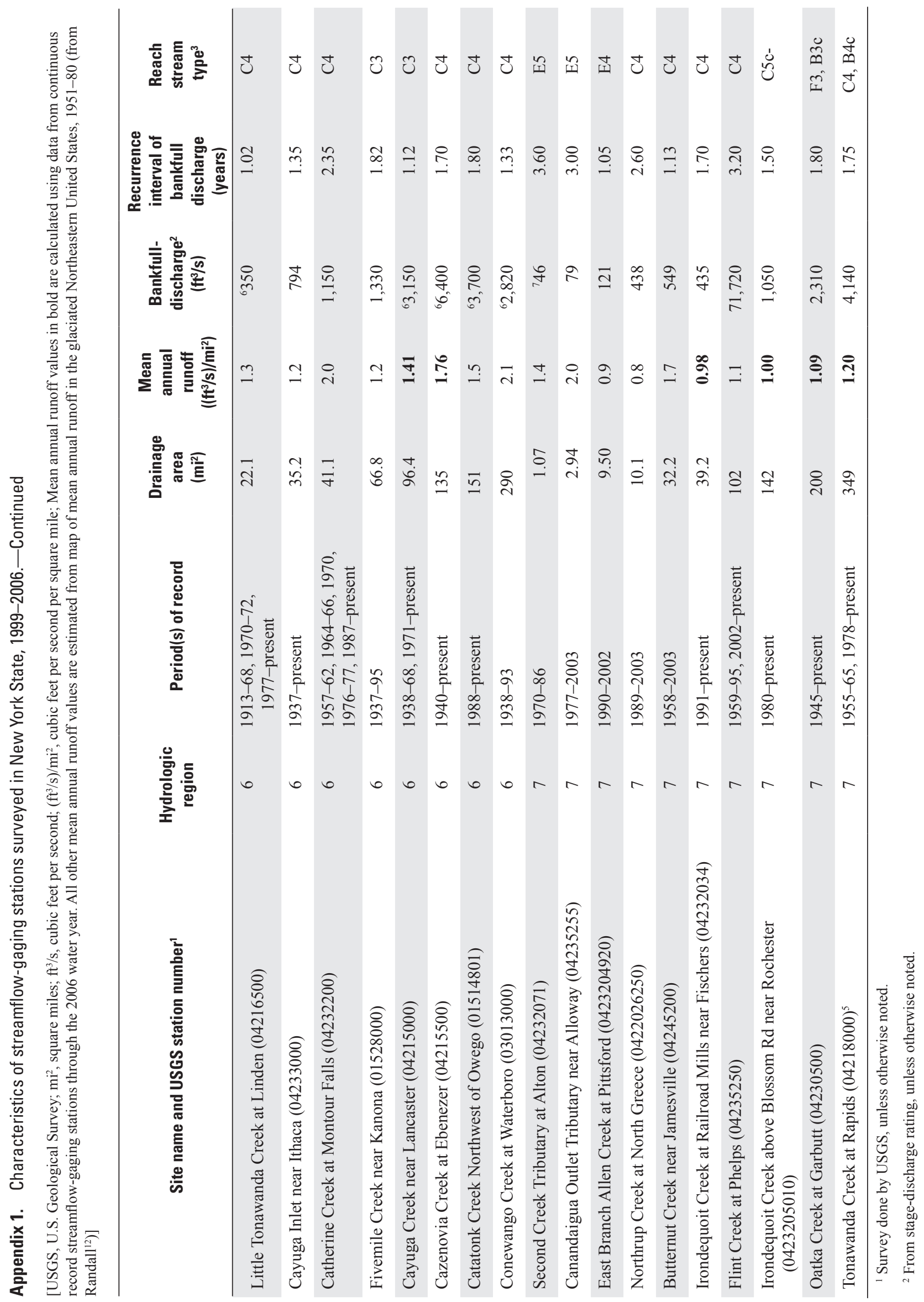


2

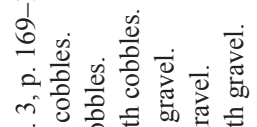

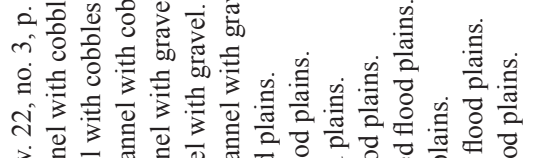

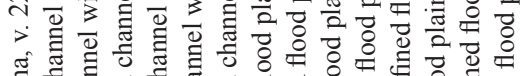

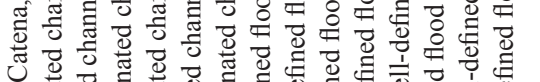

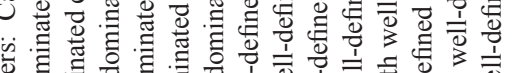

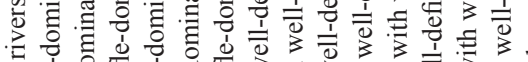

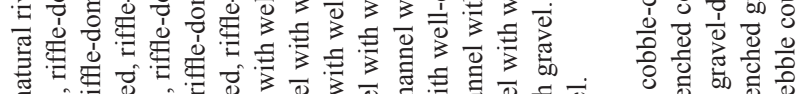

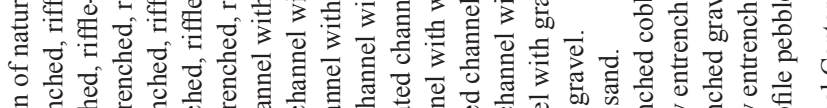

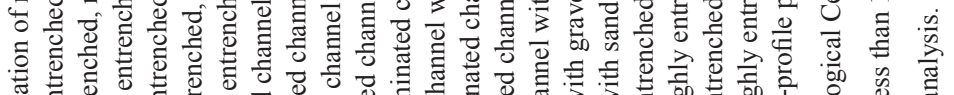

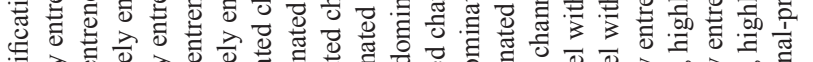

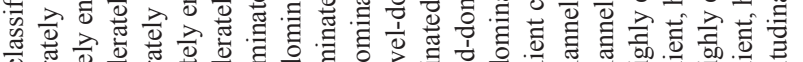

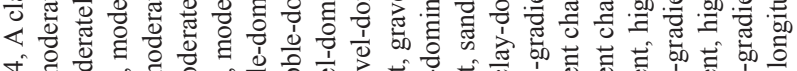

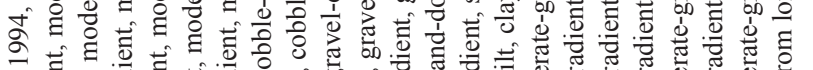

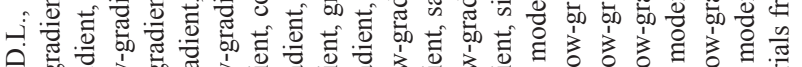

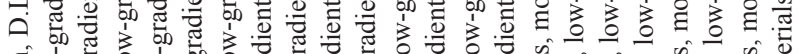

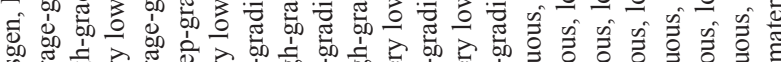

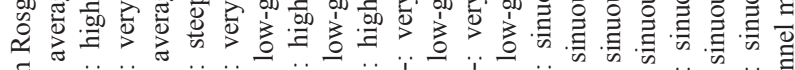

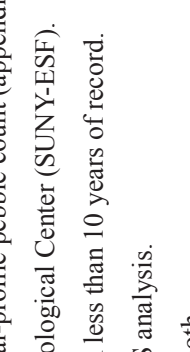

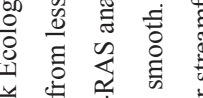
क क क 


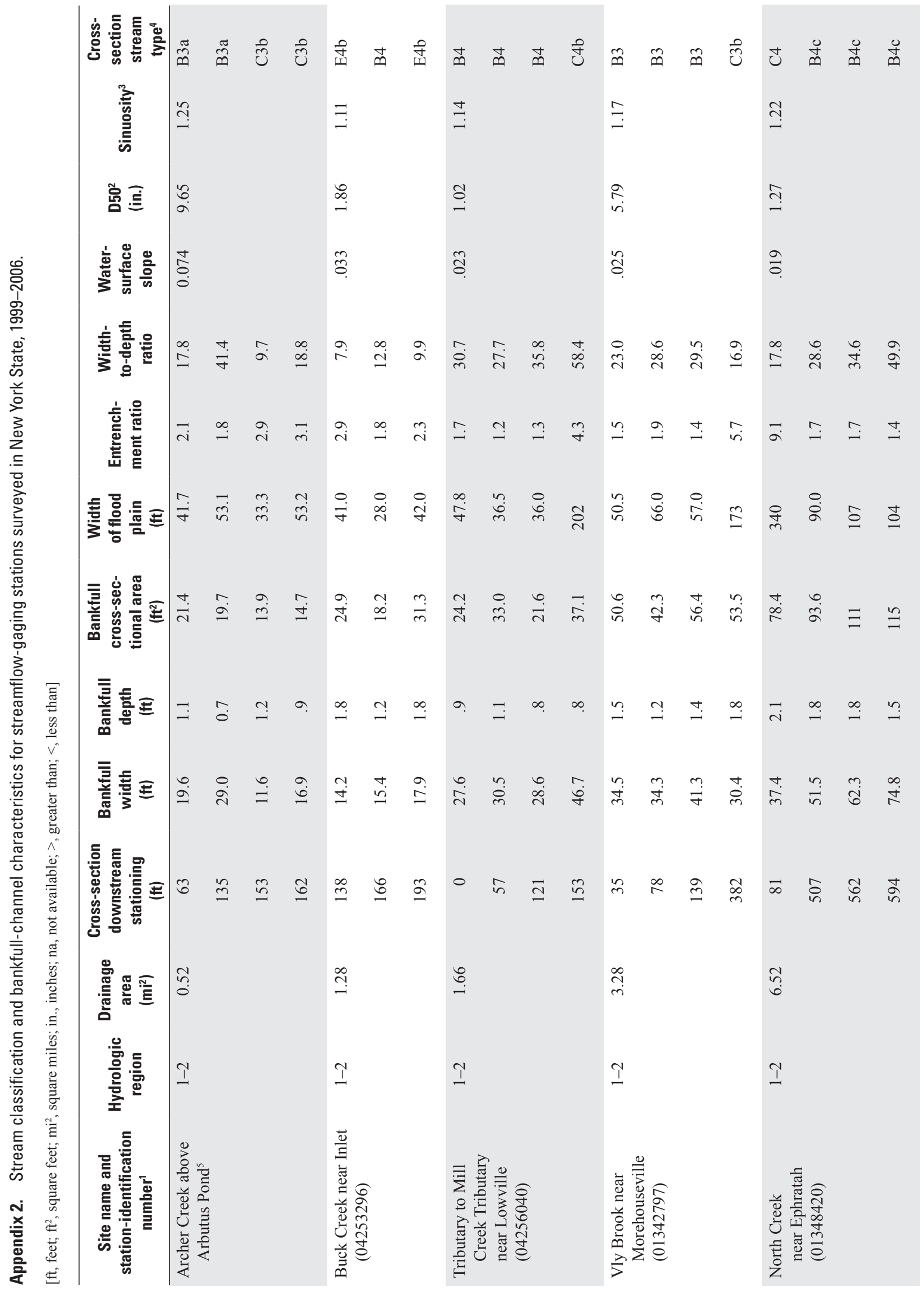




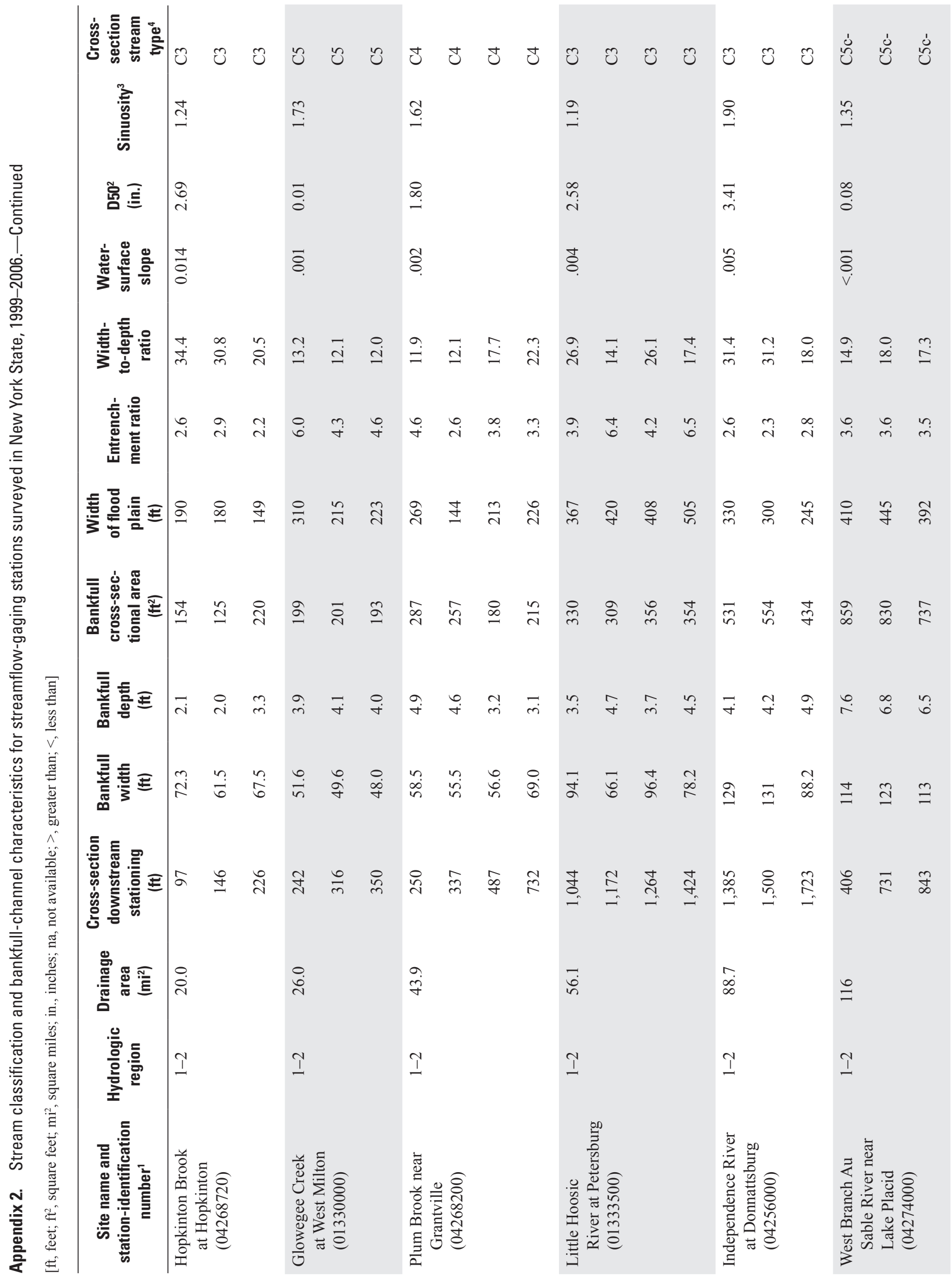




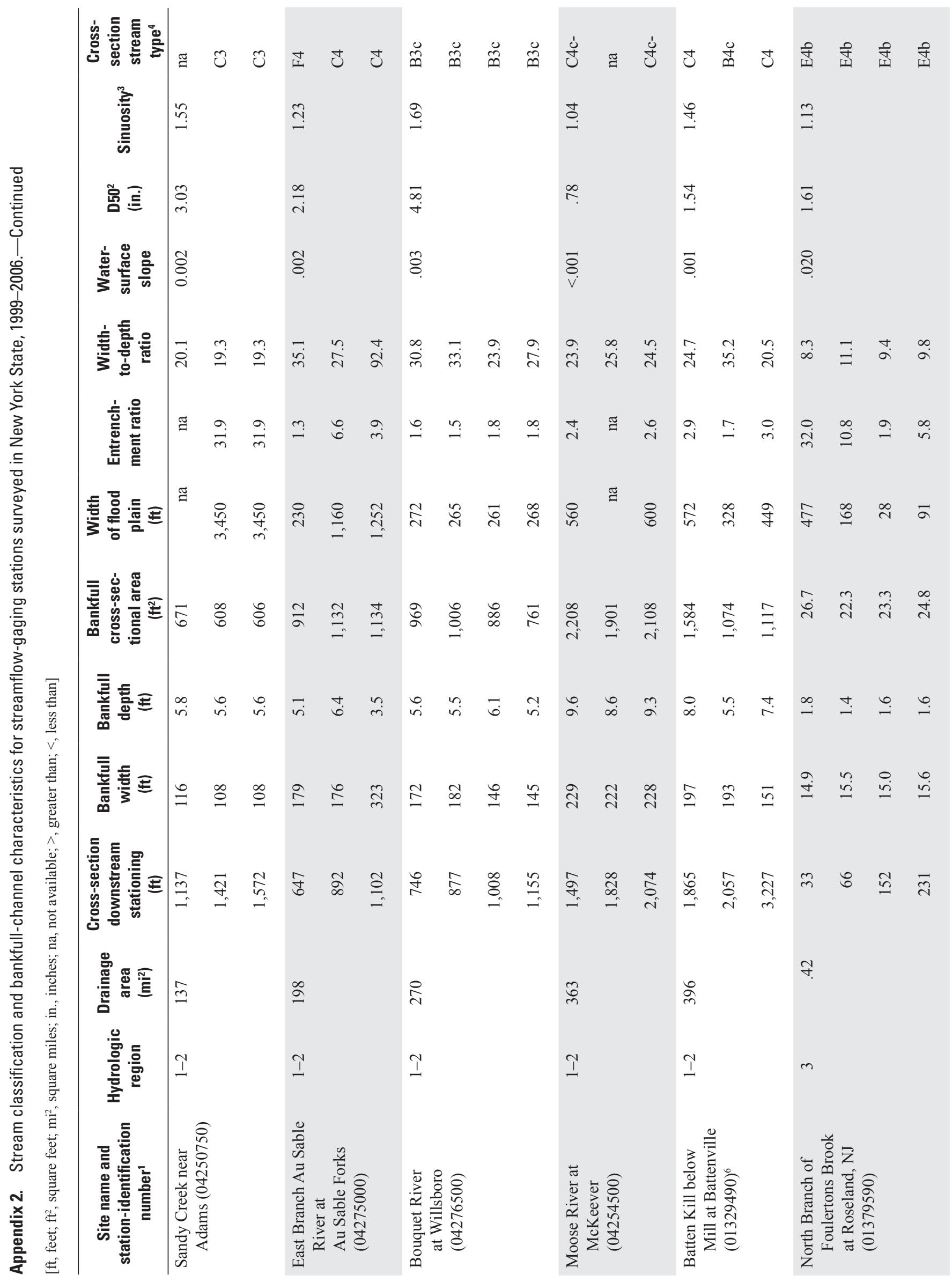




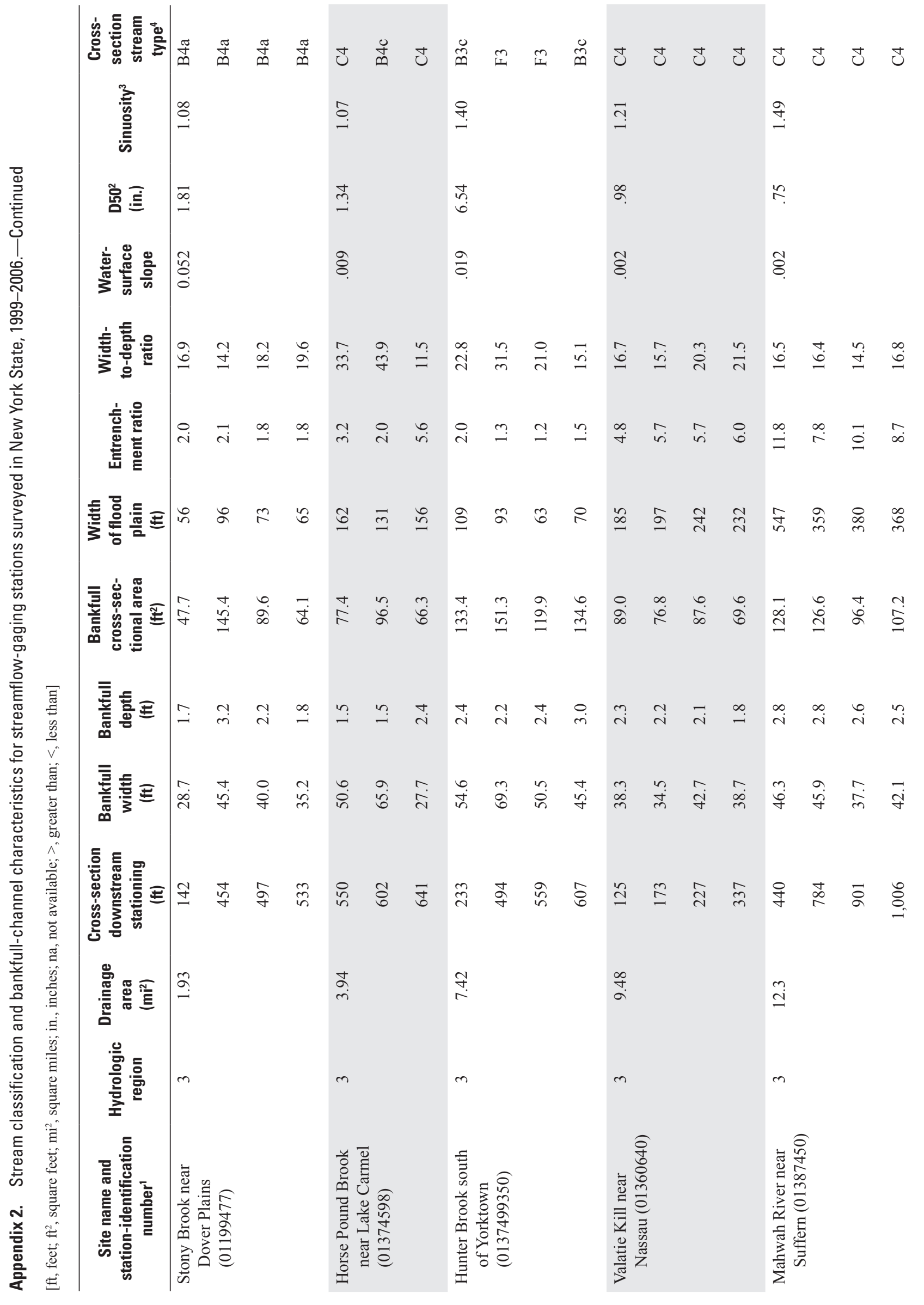




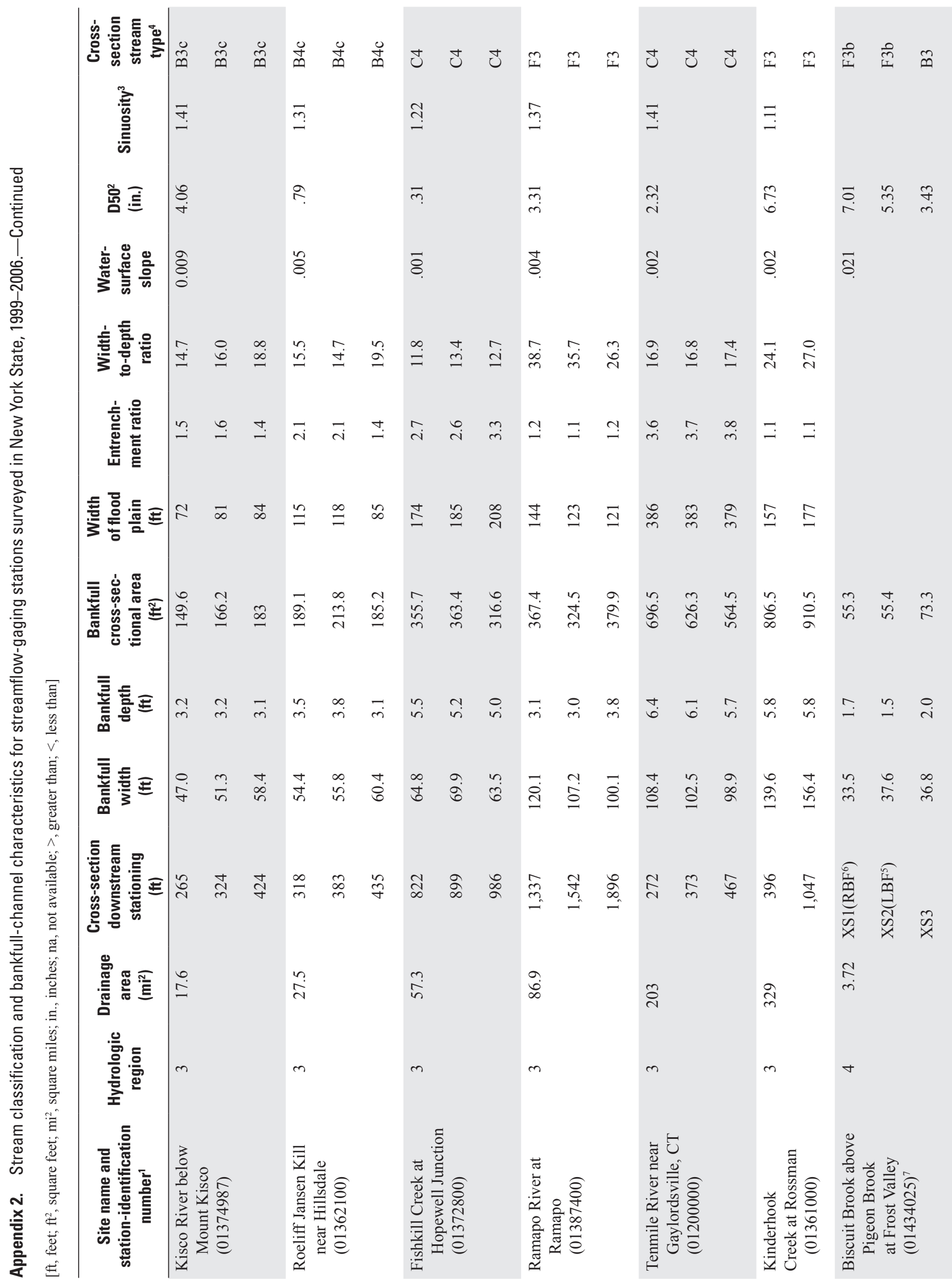




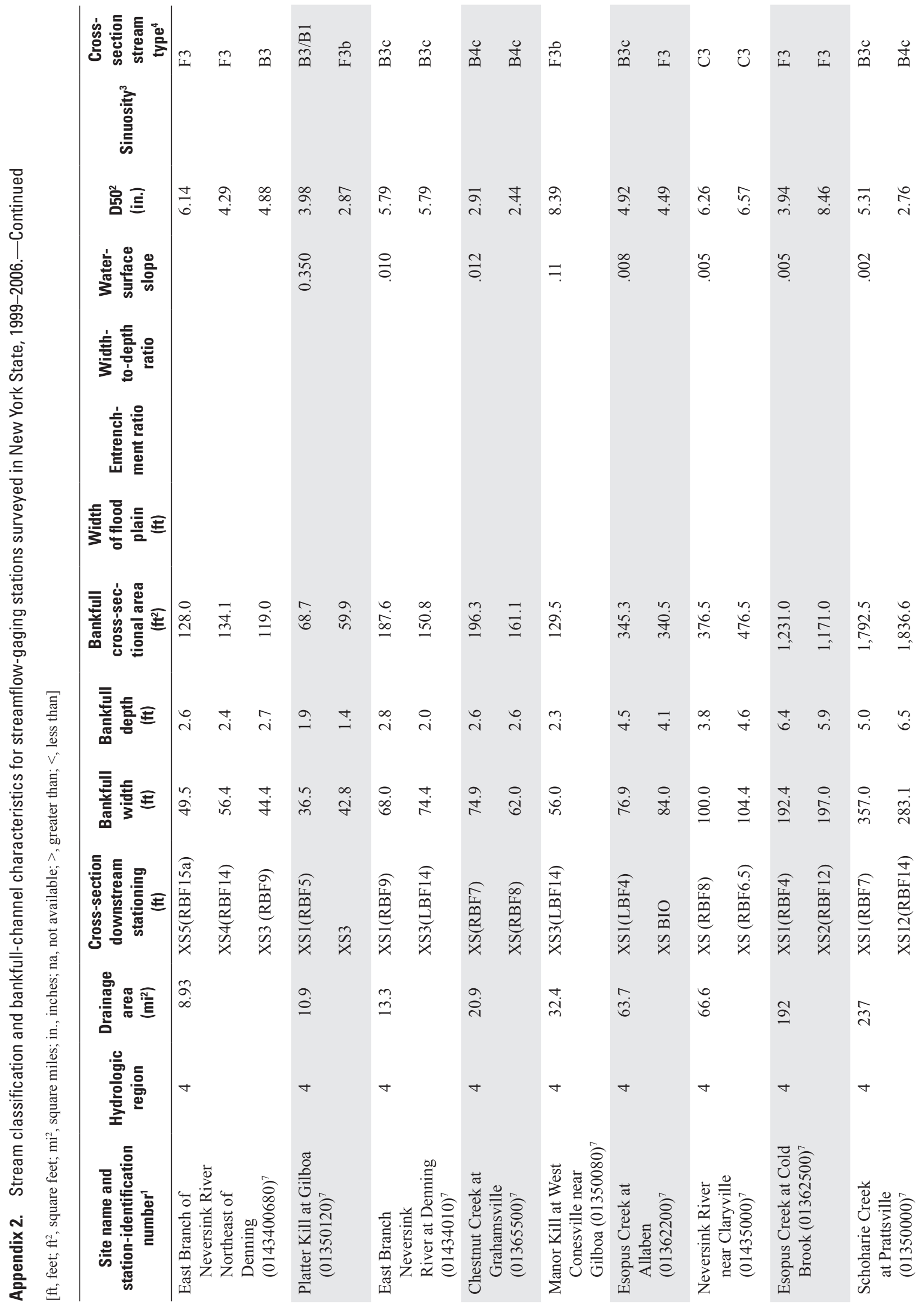




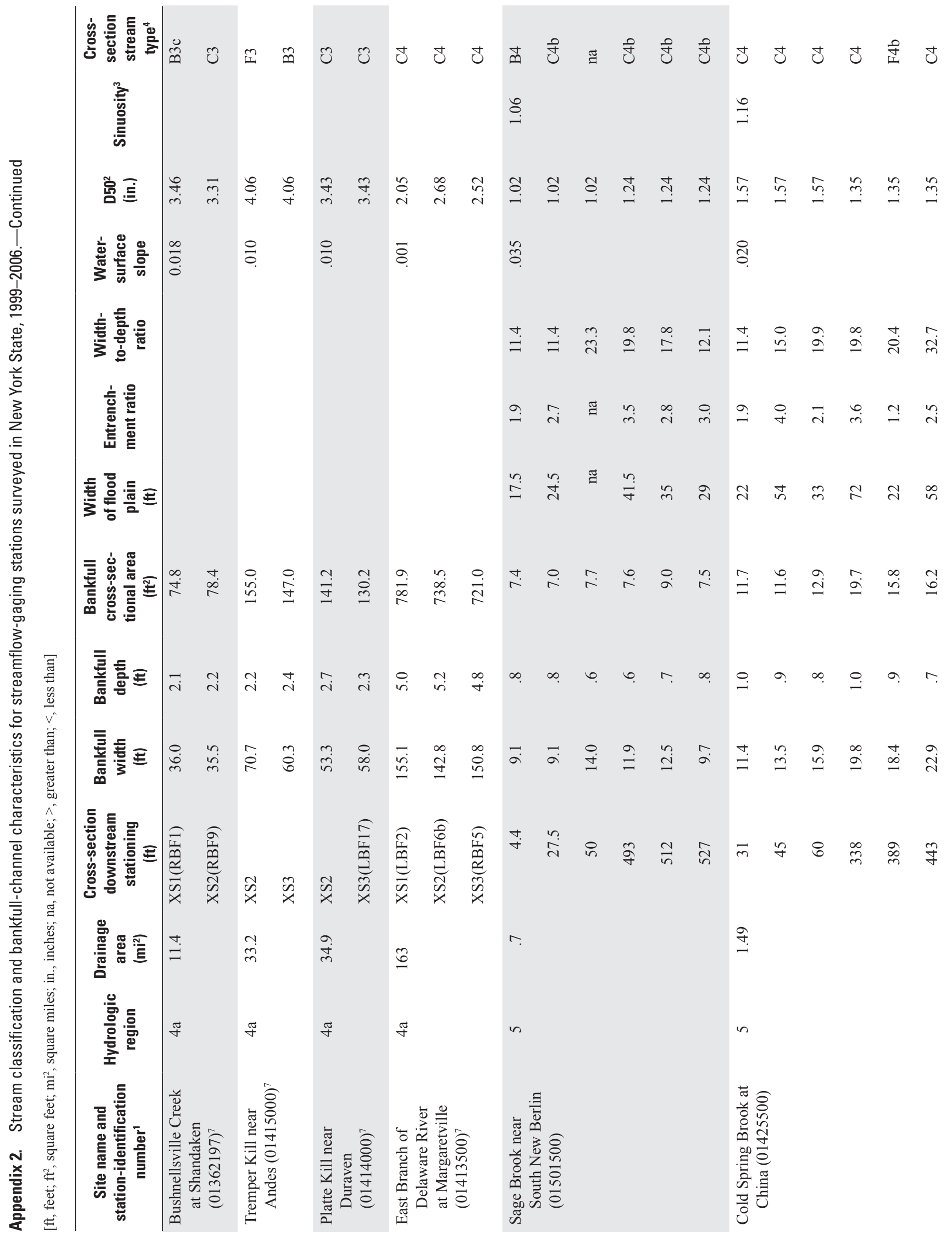




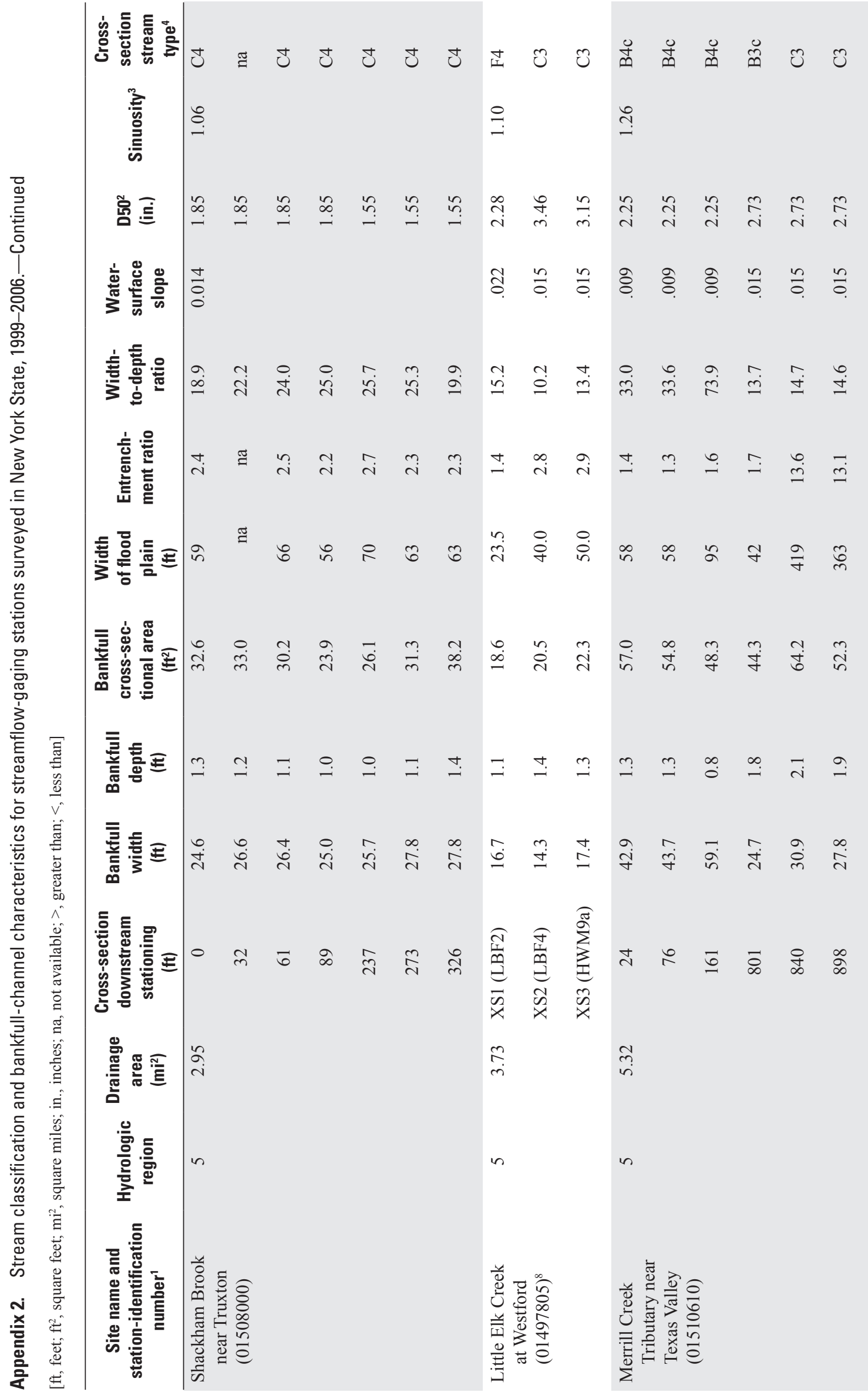




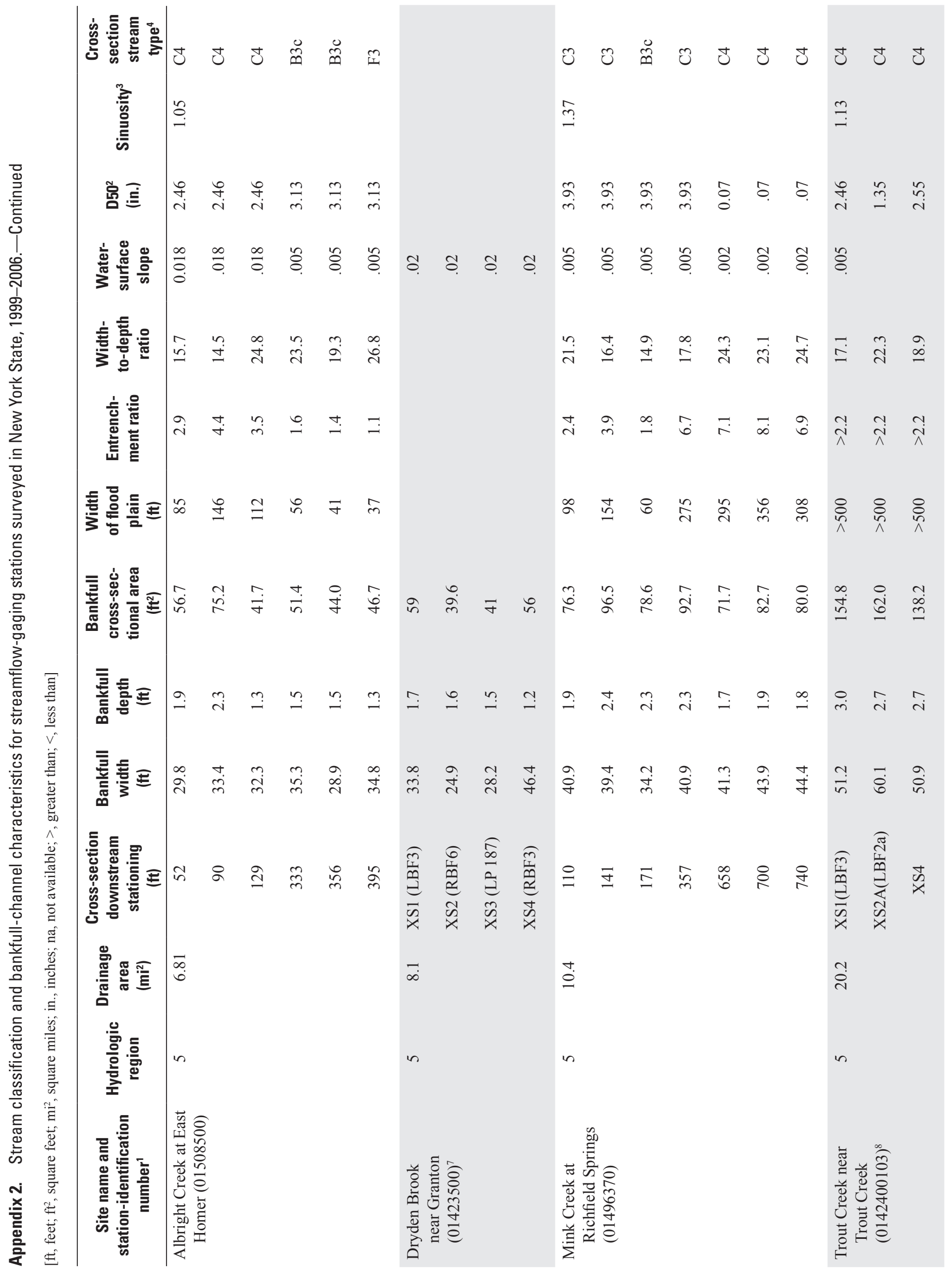




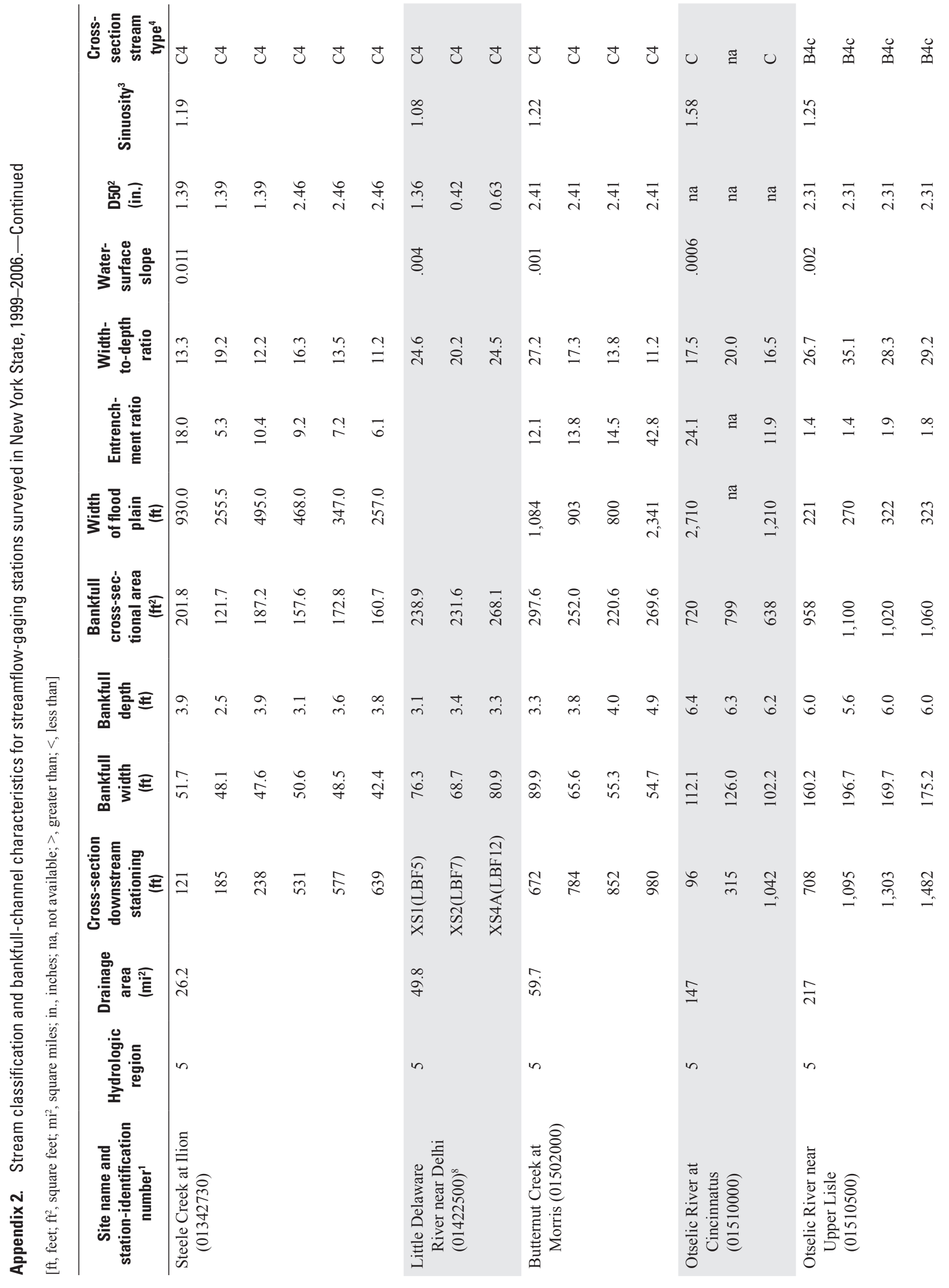




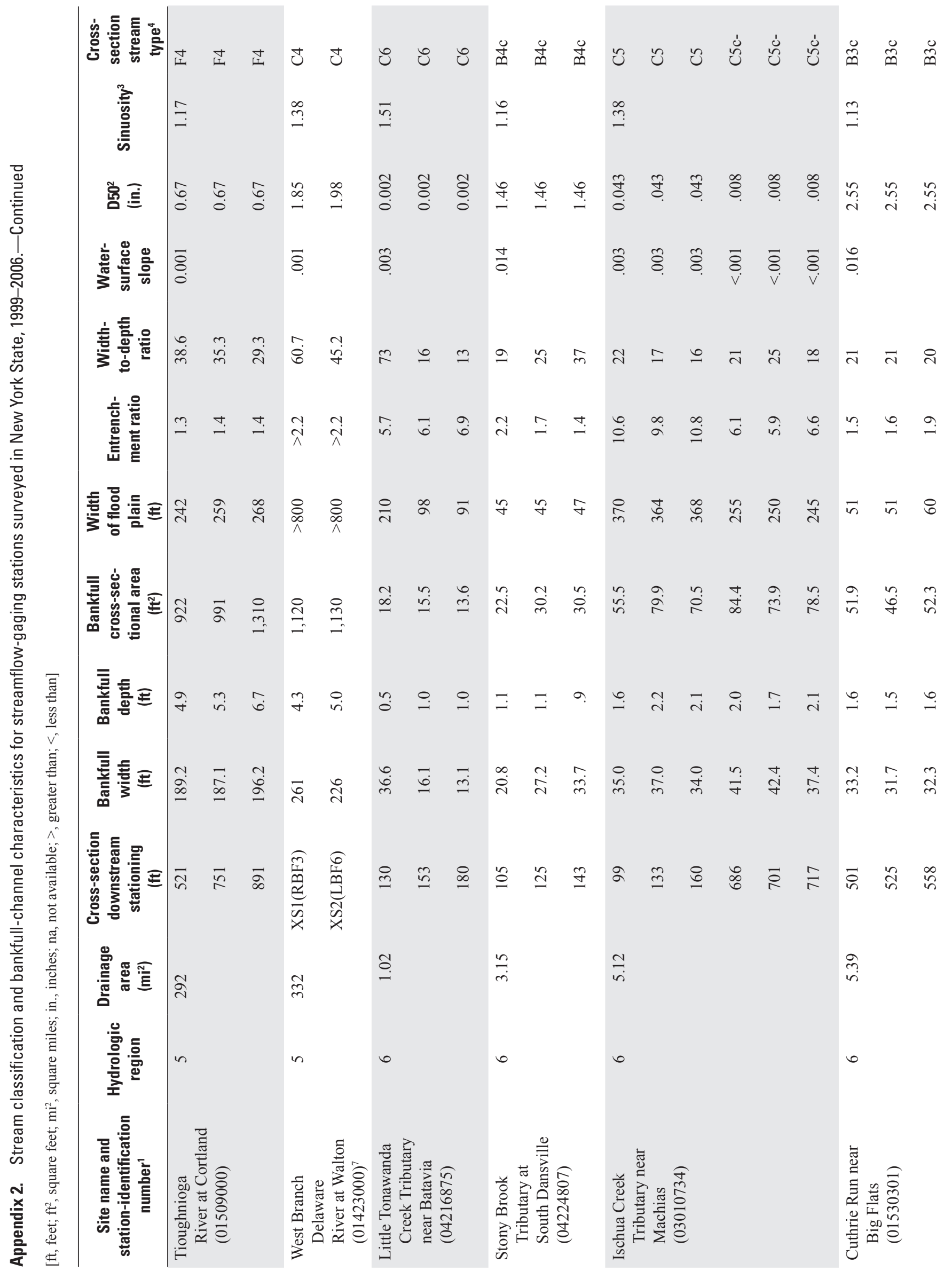




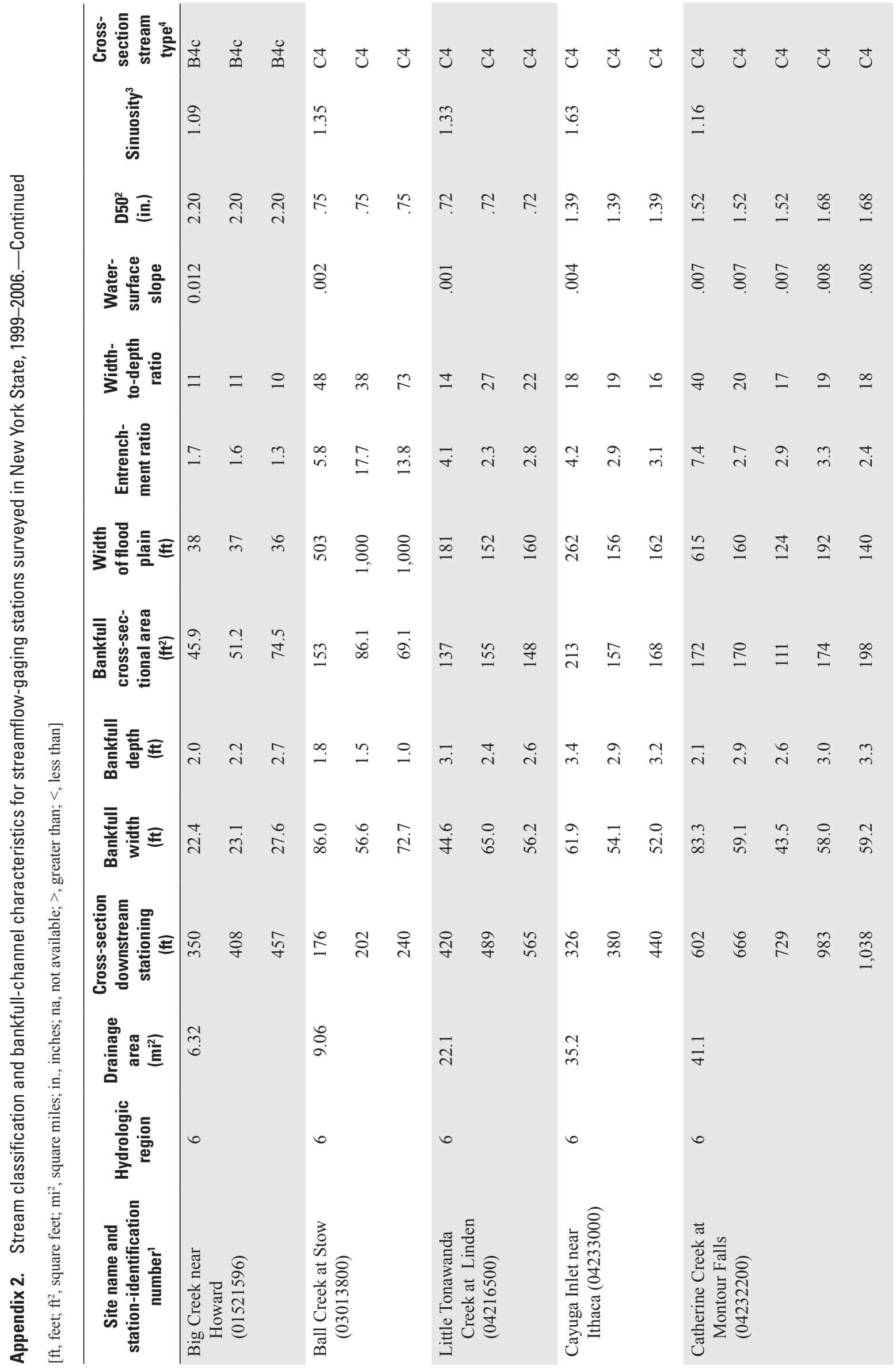




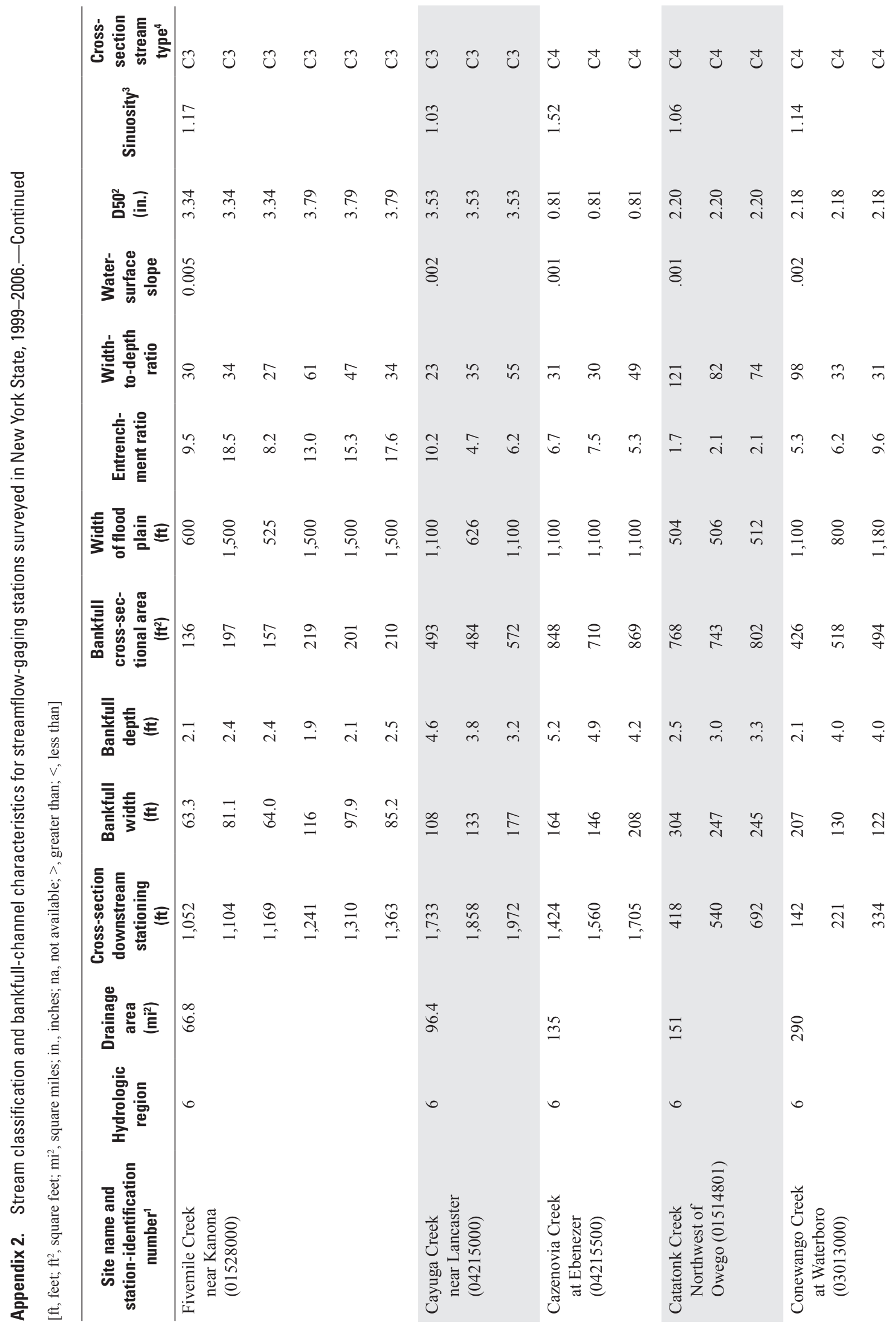




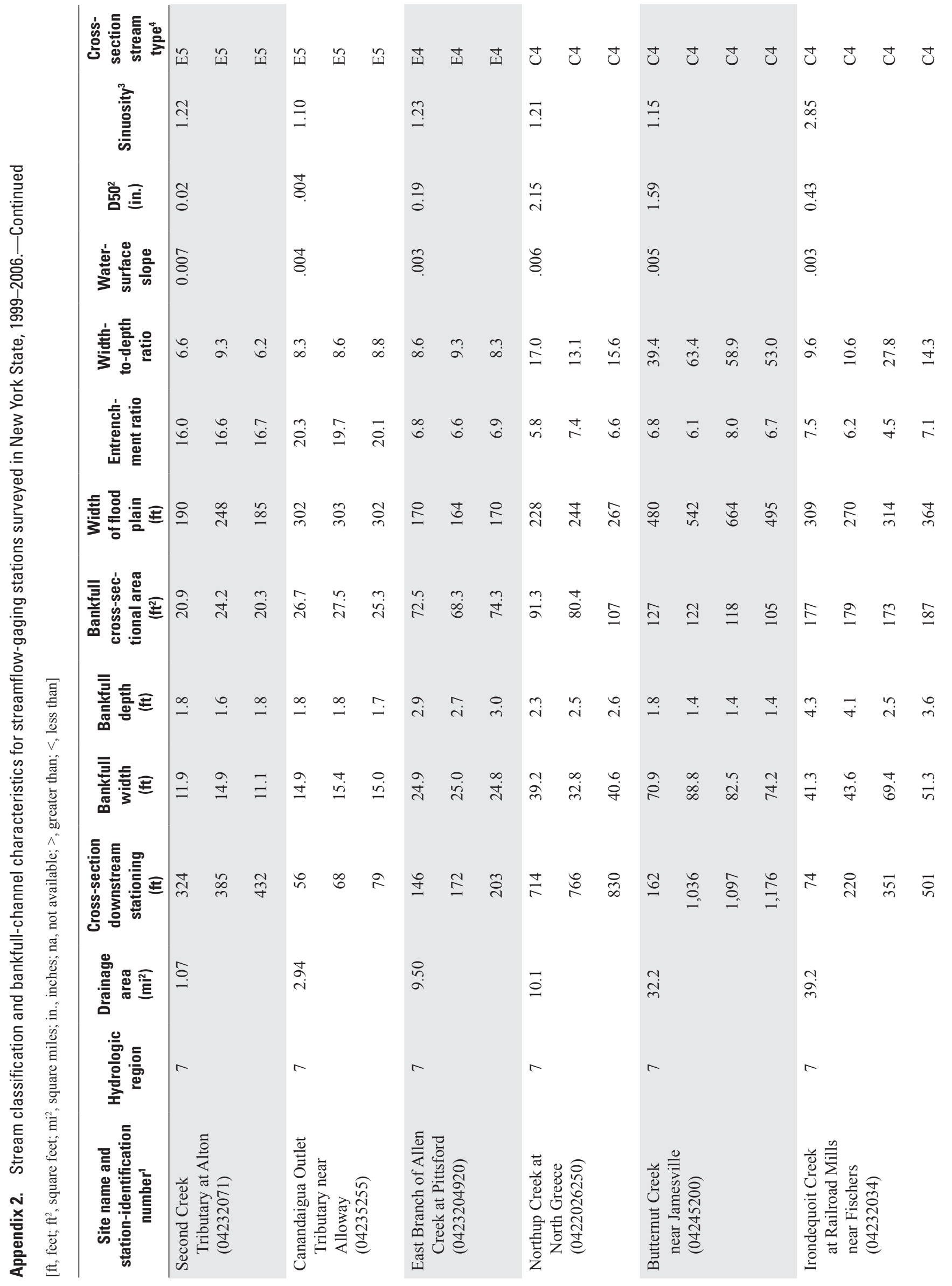




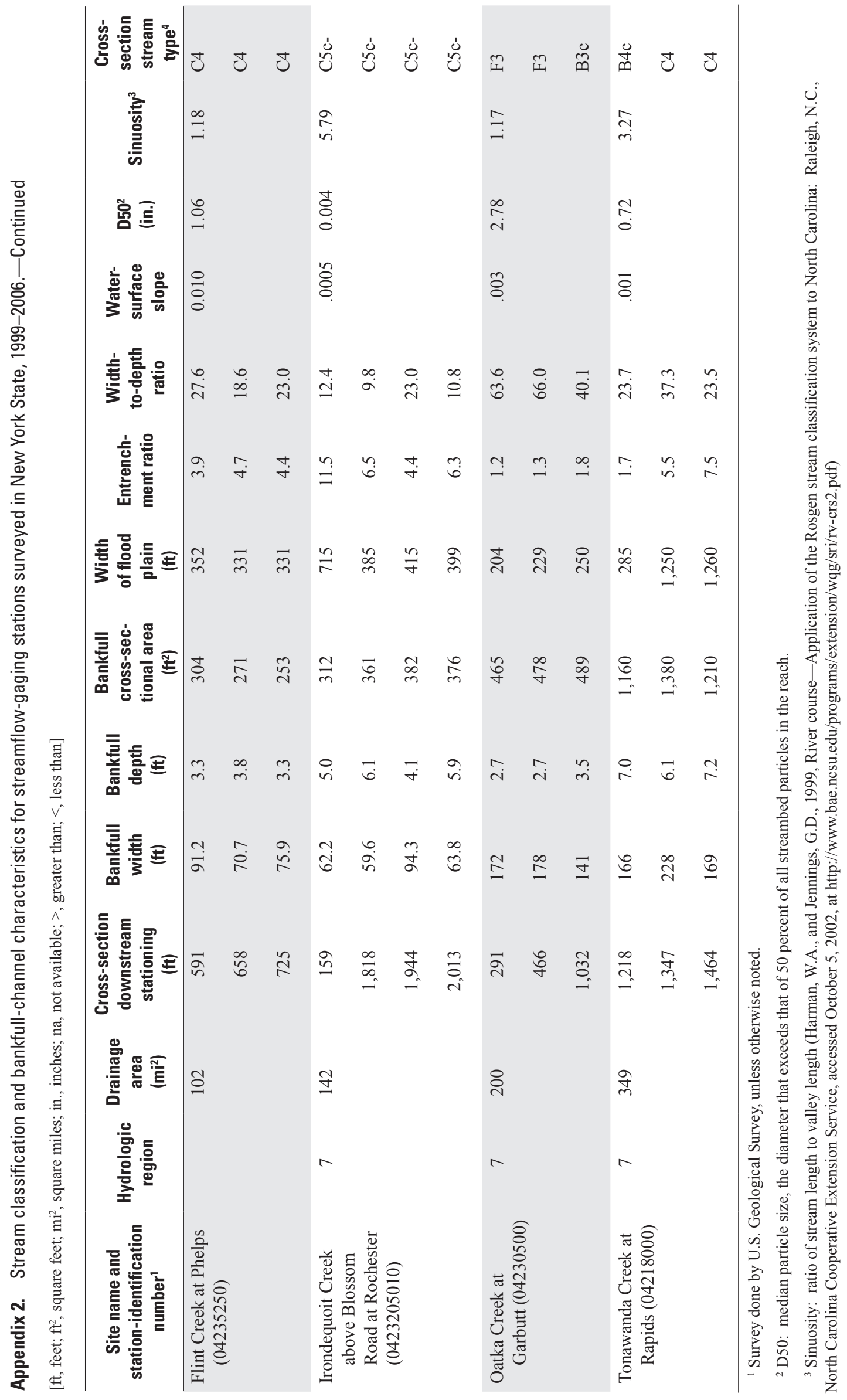



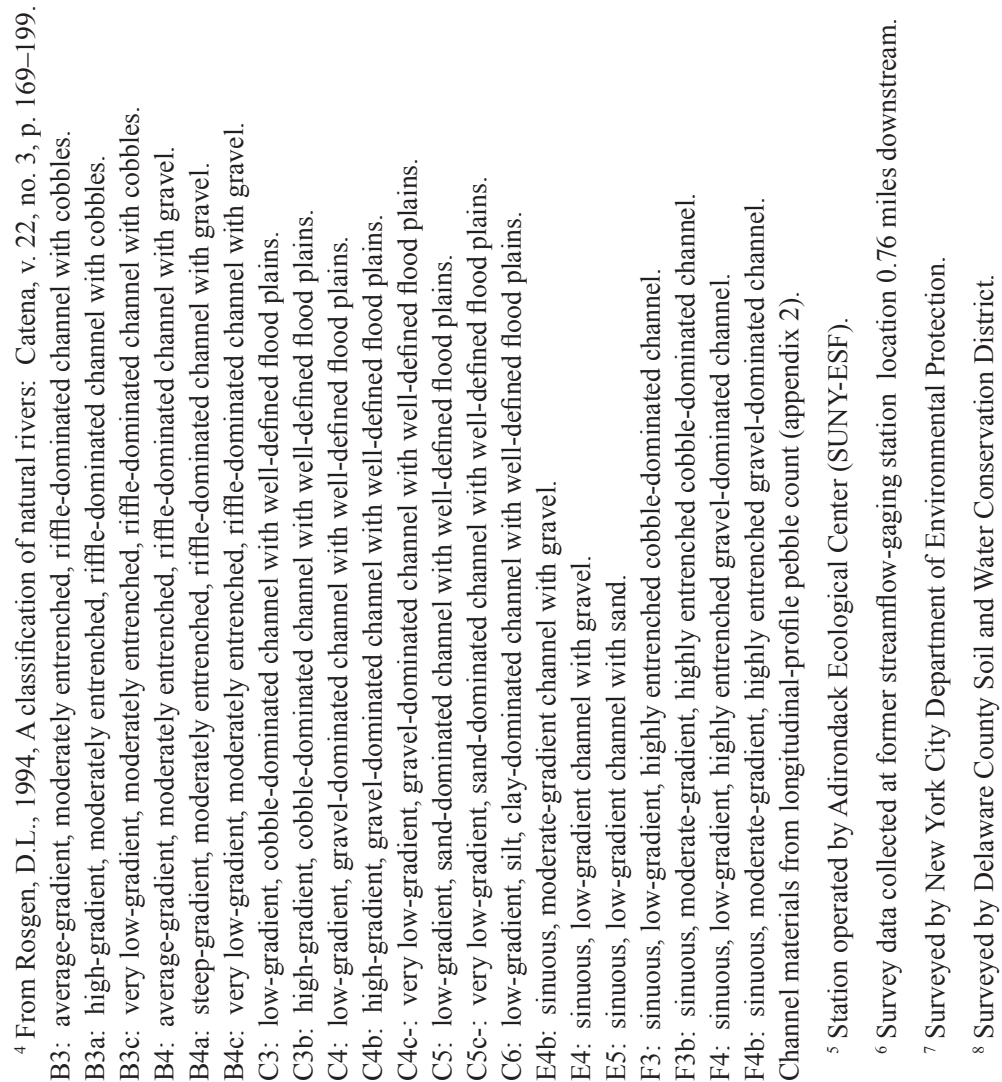
This page has been left blank intentionally. 
Prepared by the Pembroke Publishing Service Center.

For more information concerning this report, contact:

Director

U.S. Geological Survey

New York Water Science Center

425 Jordan Road

Troy, NY 12180-8349

dc_ny@usgs.gov

or visit our Web site at: http://ny.water.usgs.gov 


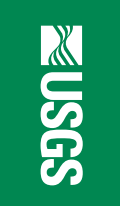

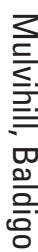

ํㅡㄹ

울

$\prod_{0}^{0}$

츨

뭉

올

ํㅡㄹ

올

$\Phi$

한

?

品

옴

号

今

之

之

읓

苟

ก․

言

총

@

ํㅜㅇ

क

응

ั.

ज 